\title{
Screening antibodies raised against the spike glycoprotein of SARS-CoV-2 to support the development of rapid antigen assays
}

Jason L. Cantera ${ }^{1 \times}$, David M. Cate ${ }^{2 \times}$, Allison Golden ${ }^{1}$, Roger B. Peck ${ }^{1}$, Lorraine L. Lillis ${ }^{1}$, Gonzalo J. Domingo ${ }^{1}$, Eileen Murphy ${ }^{1}$, Bryan C Barnhart ${ }^{3}$, Caitlin A. Anderson ${ }^{2}$, Luis F. Alonzo르. Veronika Glukhova ${ }^{2}$, Gleda Hermansky ${ }^{2}$, Brianda Barrios-Lopez ${ }^{2}$, Ethan Spencer ${ }^{2}$, Samantha Kuhn², Zeba Islam ${ }^{4}$, Benjamin D. Grant ${ }^{2}$, Lucas Kraft ${ }^{3}$, Karine Herve $^{3}$, Valentine de Puyraimond ${ }^{3}$, Yuri Hwang ${ }^{3}$, Puneet K. Dewan ${ }^{2}$, Bernhard H. Weigl ${ }^{2}$, Kevin P. Nichols ${ }^{2}$, David S. Boyle ${ }^{1^{*}}$

${ }^{1}$ PATH, 2201 Westlake Avenue, Suite 200, Seattle, WA 98121, USA.

${ }^{2}$ Global Health Laboratories, 14360 SE Eastgate Way, Bellevue, WA 98007, USA

${ }^{3}$ AbCellera Biologics inc.,2215 Yukon St, Vancouver, BC V5Y 0A1, Canada

${ }^{4}$ Intellectual Ventures Lab, 14360 SE Eastgate Way, Bellevue, WA 98007, USA

${ }^{\times}$both authors contributed equally to this work

* To whom correspondence should be addressed: $\underline{\text { dboyle@path.org }}$ 


\section{Abstract}

Severe acute respiratory coronavirus-2 (SARS-CoV-2) is a novel viral pathogen and therefore a challenge accurately diagnose infection. Asymptomatic cases are common and so it is difficult to accurately identify infected cases to support surveillance and case detection. Diagnostic test developers are working to meet the global demand for accurate and rapid diagnostic tests to support disease management. However, the focus of many of these has been on molecular diagnostic tests, and more recently serologic tests, for use in primarily high-income countries. Low- and middle-income countries typically have very limited access to molecular diagnostic testing due to fewer resources. Serologic testing is an inappropriate surrogate as the early stages of infection are not detected and misdiagnosis will promote continued transmission. Detection of infection via direct antigen testing may allow for earlier diagnosis provided such a method is sensitive. Leading SARS-CoV-2 biomarkers include spike protein, nucleocapsid protein, envelope protein, and membrane protein. This research focuses on antibodies to SARS-CoV-2 spike protein due to the number of monoclonal antibodies that have been developed for therapeutic research but also have potential diagnostic value. In this study we assessed the performance of antibodies to the spike glycoprotein, acquired from both commercial and private groups in multiplexed liquid immunoassays, with concurrent testing via a half strip lateral flow assays to indicate antibodies with potential in LFA development. These processes allow for selection of pairs of high affinity antispike antibodies are suitable for liquid immunoassays and LFA assays, some of which with sensitivity into the low picogram range with the liquid immunoassay formats with no cross reactivity to other coronavirus $S$ antigens. Discrepancies in optimal ranking was observed with the top pairs used in the liquid and LFA formats. These findings can support the development of SARS-CoV-2 LFAs and diagnostic tools.

\section{Introduction}

The appearance of a novel coronavirus disease 2019 (COVID-19) was first reported in the city of Wuhan, Hubei Province, China in 2019 ${ }^{1}$. Since then COVID-19 has progressed to pandemic levels with over 23 million reported cases including at least 800,000 associated deaths reported globally ${ }^{2}$. The pathogen responsible is the severe acute respiratory syndrome coronavirus 2 (SARS-CoV-2), a novel betacoronavirus. The coronaviruses are enveloped positive-stranded RNA viruses that are $70-90 \mathrm{~nm}$ in size and characterized by a crown like morphology associated with the display of spike (S) glycoproteins on the host membrane-derived and lipid bilayered viral envelope ${ }^{3 ; 4}$. The structure of the S glycoprotein of SARS-CoV-2 has been resolved and is known to be essential for the viral infection of the host cell via its binding to the cellular receptor angiotensin-converting enzyme 2 to promote fusion and entry into the cell ${ }^{5}$. The $S$ glycoprotein is poorly conserved across coronaviruses, with $85.3 \%$ of the antibody epitopes found in SARS CoV-2 S protein considered unique ${ }^{6 ; 7}$. Conversely, high conservation is noted across SARS CoV-2 isolates from Europe, Asia, and the US, resulting in an antigen that offers greater specificity over more conserved targets like the $\mathrm{N}$ antigen.

The rapid spread of COVID-19 has resulted in an urgent need for effective diagnostic tests to support disease management, monitoring, surveillance and pandemic control against SARS-CoV- $2^{8}$. In high income countries molecular testing, typically using real time reverse transcription PCR (RT PCR), has been the primary test method implemented to diagnose SARS-CoV-2 in both symptomatic and asymptomatic cases but the accurate detection of early infection remains challenging giving false negative results ${ }^{9 ; 10}$. As of August $24^{\text {th }}, 141$ commercial or clinical laboratory derived molecular tests have been granted emergency use authorization (EUA) in the USA by the Food and Drug Administration (FDA) ${ }^{11}$. The vast majority of the tests are predominantly unsuitable for use at the point of care as many are in open assay format with which significant engagement are needed from skilled operators to prepare the samples for testing, prepare test reagents, operate complex equipment and finally to process the data and interpret the test results. Automated high throughput molecular platforms are available and are capable of processing large numbers of samples with significantly reduced operator input ${ }^{12-15}$. However, acquiring and operating such equipment comes with high capital costs and a need for appropriate 
infrastructure, not only for housing the equipment and reagents but also requiring effective specimen collection and transport and the reporting of test data to patients, clinicians, and health care programs after processing. In the current pandemic, global demand for has affected all countries and so sufficient access to reagents, consumables and more other materials such as personnel protective equipment, swabs and transport media is necessary ensure consistent testing ${ }^{16}$.

Lack of access to key reagents and consumables has highlighted that there is a market for SARS-CoV-2 diagnostic immunoassay-based lateral flow assays (LFAs) in high income countries. Low- and middle-income countries (LMICS) already faced serious constraints in diagnostic capacity and accessibility before the COVID-19 pandemic stuck. SARS-CoV-2 will have an amplified effect in these countries that have limited access to care with and already greater burden of infectious diseases ${ }^{17}$. LMICs lack time and finances for the swift uptake of new diagnostic technologies. Furthermore, a lack of resources and skilled laboratorians limits the number of test facilities, the ability to scale testing, while access to critical reagents is limited as high-income countries dominate procurement, culminating in inability to perform molecular tests at the scale required ${ }^{18}$. Without access to expanded molecular test capacity and capability, other diagnostic tools must be developed to support COVID-19 infection control. Therefore, LFAs serve as a best alternative in regions lacking sufficient access to widespread molecular testing for SARS-coV-2.

For detection and control of COVID-19 in LMICs, an antigen LFA format makes a more viable option to the serologic LFAs that currently dominate the market due to their ability to detect SARS-CoV-2 directly and earlier in the infection process. Serology-based assays are insensitive in early infection requiring individuals to be diseased for at least a week before the antibody response can first be detected (IgA, $\operatorname{lgM}$, and/or $\lg G)^{19}$, which is enough time for infected individual to unknowingly spread the disease ${ }^{20}$. In terms of operation and cost, LFAs can be manufactured at a very large scale and at a relatively low cost per unit in comparison to molecular tests. While LFAs typically require some limited training of users, they are easy to use, give a test result in minutes, most do not require associated equipment and their use is broadly disseminated from hospitals to clinics to community-and home-based testing (e.g. malaria, HIV-1, and pregnancy testing).

The performance of antigen detection LFAs is variable depending on the performance of the antibodies used in the test and while visually read LFA reach the level of sensitivity that molecular assays offer, the use of readers can further increase test senstivity. The recent FDA EUA to Lumira Diagnostics (Stirling, UK) for their SARS-CoV-2 $\mathrm{Ag}$ assay has claims of a sensitivity of $97.6 \%$ as compared to RT PCR testing. Therefore, rapid antigen assays using high performance antibodies can offer may offer sufficient clinical sensitivity to detect infectious patients in decentralized settings where molecular testing is not readily available today. Furthermore, the LFA format can be manufactured at extremely high volumes and very low costs, and can offer increased testing capacity in LMICs where molecular testing is not readily or sufficiently. Other markets where LFAs can play a key role is in disseminated testing models such as employed in community- and home-based testing, and self-testing ${ }^{21-23}$.

The WHO's recently released target product profile for a point of care test for suspected COVID-19 cases (e.g. a rapid antigen assay) has listed the acceptable characteristics for sensitivity and specificity at $\geq 70 \%$ and $\geq 97 \%$, respectively ${ }^{24}$. A current challenge to antigen test development is understanding the performance of the SARSCoV-2 antibodies that are on or entering the market, with the screening of large numbers of unqualified antibodies a resource sink for developers aiming to develop direct antigen tests. Abundant targets include the four major structural proteins: the spike $(S)$, membrane $(M)$, envelope $(E)$ and the nucleocapsid $(N)$ proteins. The $S$ glycoprotein represented an attractive candidate due to the unique structural changes relative to SARS-COV1 and other seasonal coronaviruses, offering the potential of high specificity for SARS-COV ${ }^{6}$.

We have assessed the performance of anti-N protein antibodies via half paper LFAs in recent studies but with the spike, while a lower prevalence target, the structural role of $S$ may present better epitopes to antibodies and so could be an attractive target for a rapid LFA ${ }^{25 ; 26}$. In this study we accessed multiple antibodies targeting the $S$ 
glycoprotein by leveraging the antibody therapeutics industry and also commercially available sources. We assessed their performance for sensitivity using recombinant $S$ antigens and inactivated cultured SARS-CoV-2 virus and their sensitivity to other $\mathrm{S}$ glycoproteins from other human coronavirus species. Antibody pairs were assessed in a highly sensitive liquid immunoassay format to indicate sensitivity and specificity to the SARS-CoV-2 $S$ glycoprotein in addition to a high throughput half-strip LFA screen to identify candidates with the greatest performance as observed on nitrocellulose ${ }^{25 ; 27}$. These screens enabled us to down select and identify the optimal pairs that offer the greatest sensitivity and specificity for further development and incorporation into liquid and LFA immunoassay formats for direct antigen detection of SARS-CoV-2 virus via the S glycoprotein.

\section{Materials and Methods}

\section{Antibodies and Antigens}

Antibodies to the $S$ glycoprotein were procured from Leinco Technologies (Fenton, MO, USA), Sino Biological (Wayne, PA, USA), Cedar Lane (Burlington, NC, USA), and Creative Diagnostics (Shirley, NY, USA). AbCellera Biologics Inc. (Vancouver, BC, Canada) provided a private collection of 41 recombinant antibodies engineered from B cells harvested from a convalescent patient after SARS-CoV-2 infection. A list of all anti-spike antibodies screened in this work are provided in Table 1si (suppl. info).

The full-length trimeric SARS-CoV-2 Spike antigens expressed in mammalian cells were purchased from Acro Biosystems (Newark, DE, USA), and Leinco Technologies or made in-house (Global Health Labs only). S antigens expressed in Baculovirus-insect cells were obtained from Sino Biological and Biodefense and Emerging Infections Research Resources Repository (BEI Resources, Manassas, VA, USA). Heat-inactivated and gamma-irradiated cell culture lysates of SARS-CoV-2, and irradiated cell culture lysates of the middle eastern respiratory syndrome virus (MERS) and SARS-CoV-1 were also acquired from BEI Resources. Titered HEK293 cell culture supernatants of human coronaviruses OC43 and 229E were generously gifted from the laboratory of Dr Scott Meschke, University of Washington (Seattle, WA, USA). SARS-CoV-2 positive and negative nasopharyngeal specimens were acquired from the Washington COVID-19 Biorepository ${ }^{28}$. These samples were discarded clinical specimen from a laboratory that used the Applied Biosystems TaqPath COVID-19 assay (ThermoFisher Scientific, Waltham, MA, USA), a SARS-CoV-2 RT PCR assay with FDA EUA.

\section{Viral load determination via qRT-PCR}

Clinical specimens were prepared in one of two ways. 1) RNA was extracted from $50 \mu \mathrm{L}$ of specimen using the QIAamp Viral RNA Mini Kit (Qiagen, Valencia, USA) according to the manufacturer's instructions 2) $40 \mu \mathrm{L}$ of specimen were heated to $95^{\circ} \mathrm{C}$ for 10 mins to lyse virions. Next, $5 \mu \mathrm{L}$ of extracted RNA or $2.5 \mu \mathrm{L}$ of heat-treated specimens were added to qRT-PCR reactions containing TaqPath ${ }^{\text {TM }}$ 1-Step RT-qPCR Master Mix (ThermoFisher Scientific) and the Centers for Disease Control and Prevention N1 primer set (IDT, Coralville, USA). Reactions were carried out per the CDC protocol with an ABI7300 Fast Real-Time PCR System (Applied Biosystems). A standard curve was generated using quantified genomic RNA from SARS-Related Coronavirus 2, Isolate USAWA1/2020, NR-52285 (BEI Resources) and used to determine the viral load of each sample.

\section{Liquid Immunoassay Screening for Optimal Antibody Pairs}

\section{Labelling of antibodies for use on the Meso Scale Discovery immunoassay platform}

Per the protocol, two aliquots of each antibody $(100 \mu \mathrm{g} / \mathrm{mL})$ were labelled with biotin (EZ-Link Sulfo-NHS-LCBiotinylation Kit, ThermoFisher Scientific) for capture and SULFO-TAG (GOLD SULFO-TAG NHS-Ester) for detection using the Meso Scale Discovery (MSD, Rockville, MD, USA) electrochemiluminescent immunoassay platform. Unbound biotin or SULFO-TAG was removed using Zeba ${ }^{\mathrm{TM}}$ spin desalting columns (ThermoFisher 
Scientific), and the incorporation ratio for each label was measured. Briefly, the concentration of biotinylated antibodies after desalting was measured at $280 \mathrm{~nm}$ via spectrophotometer (Nanodrop ND-1000, ThermoFisher Scientific); biotin incorporation was measured using a Biotin quantification kit (Pierce ${ }^{\mathrm{TM}}$, ThermoFisher Scientific). For measuring the incorporation of the SULFO-TAG, the protein concentration was estimated using the bicinchoninic acid (BCA) protein assay (ThermoFisher Scientific), and the SULFO-TAG label spectrophotometrically measured at $455 \mathrm{~nm}$.

\section{Preparation of U-plex plates}

The biotinylated capture antibodies were coupled via biotin-streptavidin binding to U-PLEX linkers. To prepare the capture antibody arrays, up to 10 antibody-linker conjugates were pooled together in U-PLEX stop buffer at a concentration of $0.29 \mu \mathrm{g} / \mathrm{mL}$ per antibody, and $50 \mu \mathrm{L}$ of this mixture was added to individual wells of the UPLEX plates. The plates were incubated for 1 hour with shaking $(500 \mathrm{rpm})$ to allow the antibody array to selfassemble to the complimentary antibody linker binding sites and unbound material then removed by washing 3 times with $150 \mu \mathrm{L} /$ well of phosphate buffered saline $+0.05 \%$ Tween 20 (PBS-T, pH 7.5) using a BioTek ELX405R microplate washer (BioTek Instruments Inc., Winooski, VT, USA).

\section{Processing U-plex plates}

Appropriate serial dilutions of the trimeric S glycoprotein in Diluent 100 (MSD) were prepared. Clinical specimens and cell lysates were prepared by adding $25 \mu \mathrm{L}$ into $25 \mu \mathrm{L}$ of Diluent 100 . The $50 \mu \mathrm{L}$ of each prepared sample was added to each antibody array well in the U-PLEX plate, and incubated with shaking for 1 hour at room temperature. Plates were washed 3 times in $1 X$ PBST and then $25 \mu \mathrm{L}$ of $2 \mu \mathrm{g} / \mathrm{mL}$ SULFO-TAG-labeled detection antibody in Diluent 3 (MSD) was added to each well with incubation for an hour with shaking. Plates were then washed 3 times to remove excess detection reagent and the wells filled with $150 \mu \mathrm{L}$ of $2 \mathrm{X}$ read buffer T (MSD). The plates were inserted into the MESO QuickPlex SQ 120 plate reader (MSD) and the electrochemiluminescence (ECL) from each individual array spot was subsequently measured. In the absence of a control, the array spot that gave the highest signal to noise in each plate was expressed as $100 \%$ and each of the array spots in each plate expressed as percentile of this value. When serial dilutions of the $S$ glycoprotein were used to generate a calibration curve, the relationship of $E C L$ signal to $S$ glycoprotein concentration was then fitted to a four-parameter logistic (4-PL) function in the Discovery Workbench v4 program. S glycoprotein concentrations for gamma-irradiated SARS-CoV-2 were calculated by back-fitting ECL signals to the 4-PL fit.

\section{Antibody Evaluation}

The identification of the optimal antibody pairs for capture and detection of the $S$ glycoprotein was determined via a three-stage process using the MSD immunoassay platform. MSD U-plex plates with a 10-plex array/well format were prepared for capture antibody binding as above. Antibodies were screened in a matrix format, acting both as capture and detector antibody.

Round 1. All 41 AbCellera antibodies were screened together in a matrix format using $10 \mathrm{ng} / \mathrm{mL}$ of trimeric $\mathrm{S}$ glycoprotein antigen (Acro Biosystems) in triplicate. The capture and detection antibody pairs that recorded $25 \%$ or greater ECL per plate were further evaluated over a greater range of $S$ antigen concentration (1000, 100 and $10 \mathrm{ng} / \mathrm{mL}$ ) to verify the initial results. The highest $\mathrm{ECL}$ readings across each concentration ranges were then used to rank antibodies for round 2 screening.

Round 2. Six antibody candidates from round 1 were evaluated further in a matrixed format alongside 3 antibodies from Sino Biological using 7-point dilutions of the $S$ glycoprotein antigen in diluent 100 (ranging from 1250 to $0.016 \mathrm{pg} / \mathrm{mL}$ ) in duplicate. Antibody pairs were ranked in terms of the limit of detection (LOD). Specificity was evaluated by challenging the pairs with irradiated viral cultures of SARS-CoV-2 and other human coronavirus species at concentrations equivalent to $10^{4} \mathrm{TCID}_{50} / \mathrm{mL}$ or PFU/mL in Diluent 100. 
Round 3: An additional 4 antibodies from Leinco were evaluated in a matrix format with the 4 best performing antibodies from round 2 and 2 from round 1 . Their analytical sensitivity was evaluated by challenging the antibody pairs with a 7-point calibration curve of the $S$ antigen, and a dilution series of the irradiated SARS-CoV2. Specificity was evaluated by challenging the pairs with irradiated viral cultures and supernates of other human coronavirus species (OC43,229E, MERS and SARS) at concentrations equivalent to $10^{4} \mathrm{TCID}_{50} / \mathrm{mL}$ or PFU/mL in Diluent 100. Antibody pairs were ranked in terms of LOD and ECL signal with the best performing pair further evaluated for clinical sensitivity and specificity with 53 clinical specimens.

\section{Lateral flow assay Screening for Optimal Antibody Pairs}

\section{Antibody/antigen evaluation by SDS-PAGE}

Antigens were evaluated for purity and size using SDS-PAGE. Concentration was measured for all proteins using BCA assay (ThermoFisher Scientific). Samples were premixed NuPAGE ${ }^{\text {TM }}$ LDS 4x Sample Buffer (ThermoFisher Scientific) and heated at $70^{\circ} \mathrm{C}$ for 10 minutes. Gels with a $4-12 \%$ Bis-Tris gradient were used to achieve separation. Novex Sharp Pre-stained protein standard (ThermoFisher Scientific) was used as a molecular weight marker Coomassie Imperial ${ }^{\text {TM }}$ Protein Stain (ThermoFisher Scientific) was used to stain each gel and visualize protein bands.

\section{Latex bead conjugation}

For both test and control line detection conjugates, $400 \mathrm{~nm}$ carboxylic blue latex beads (Magsphere, Pasadena $\mathrm{CA}$, USA) were washed three times with 0.1 M MES buffer ( $\mathrm{pH} 6)$. Then, latex beads were activated using 1ethyl-3-(3-dimethylaminopropyl)carbodiimide hydrochloride / $\mathrm{N}$-hydroxysuccinimide (ThermoFisher Scientific) coupling reagents at 0.15 and $10 \mathrm{mg} / \mathrm{mL}$ respectively for 30 minutes. Afterwards, the blue latex particles were conjugated in 1× PBS (pH 7.2) to various anti-spike antibodies at a w/w ratio of 20:1 and 10:1 (bead: antibody) for test and control line antibodies, respectively, for three hours. Finally, latex conjugates were quenched using $0.1 \mathrm{M}$ ethanolamine before being washed and blocked with $6 \%(\mathrm{w} / \mathrm{v})$ casein in $\mathrm{H}_{2} \mathrm{O}$ (preparation method is proprietary), final concentration $1.2 \%$, overnight. The latex conjugates were stored in buffer containing $50 \mathrm{mM}$ borate $(\mathrm{pH} 8.5)$ and $1 \%$ casein. The latex conjugates were quantified using the spectrophotometer by measuring absorbance at $660 \mathrm{~nm}$ and comparing to absorbance of unconjugated beads.

\section{LFA reagent deposition and strip assembly}

Unlabeled capture antibodies were diluted to $1 \mathrm{mg} / \mathrm{mL}$ in $1 \times \mathrm{PBS}(\mathrm{pH} 7.4)$ with $2.5 \%(\mathrm{w} / \mathrm{v})$ sucrose, and were striped at $1 \mu \mathrm{L} / \mathrm{cm}$ (ZX1010, BioDot, Irvine, CA, USA) on nitrocellulose CN95 (20 mm wide, CN95, Sartorius Lab Instruments GmbH \& Co. KG, Otto-Brenner-Straße 20, Göttingen, Germany) and dried at $25^{\circ} \mathrm{C}$ for $30 \mathrm{~min}$. The control line was $0.75 \mathrm{mg} / \mathrm{mL}$ Donkey anti-Chicken IgY (Jackson ImmunoResearch, West Grove, PA, USA), striped at $1 \mu \mathrm{L} / \mathrm{cm}$. The test and control lines were located at $8 \mathrm{~mm}$ and $13 \mathrm{~mm}$ from the upstream edge of the nitrocellulose membrane. For antibody screening, the nitrocellulose was left unblocked.

The conjugate pad was dip-coated with two blocking solutions. First, 6613 conjugate pads (Ahlstrom-Munksjö Helsinki, Finland) were soaked in a $0.05 \%(\mathrm{w} / \mathrm{v})$ Tween-20 in $\mathrm{diH}_{2} \mathrm{O}$ solution for $15-20$ seconds and dried at $40^{\circ} \mathrm{C}$ for $60 \mathrm{~min}$. Pads were again soaked in $50 \mathrm{mM}$ borate $(\mathrm{pH} 8.5) ; 0.25 \%(\mathrm{w} / \mathrm{v})$ Triton X-100; $1 \%(\mathrm{w} / \mathrm{v})$ Surfactant10G; $1 \%(\mathrm{w} / \mathrm{v})$ sucrose; and $6 \%(\mathrm{w} / \mathrm{v})$ casein for another 15-20 seconds. The conjugate pad was dried for $60 \mathrm{~min}$ at $40^{\circ} \mathrm{C}$ before assembly. 
Card assembly was performed on a clamshell laminator (Matrix 2210, Kinematic Automation, Sonora, CA, USA). Pads were placed on the backing card in the following order: nitrocellulose, cover tape, conjugate pad, sample pad, wicking pad. Individual strips ( $3.3 \mathrm{~mm}$ wide) were cut with a Matrix 2360 sheet cutter (Kinematic Automation, Mono Vista, CA, USA) and assembled in cassettes (proprietary design) using an assembly roller (YK725, Kinbio Tech Co., Shanghai, China).

\section{Hamilton screening procedure for LFA screening of antibodies}

Antibody pairs were screened on an integrated robotic system we have previously used to test antibody performance directly on nitrocellulose ${ }^{25 ; 27}$. In this system, the Hamilton STAR automated liquid handling robot (Hamilton Company, Reno, NV, USA), camera (IDS UI-1460SE-C-H detector with a Tamron M118FM16 lens) custom LFA holders, and custom control software developed in-house were combined to allow rapid screening of antibody pairs directly in LFA format. The robot used 8-channel pipetting for parallel application to LFAs and the camera for imaging. The custom LFA framework held a maximum of 96 LFA cassettes per robot run. The custom control software applied $1 \mu \mathrm{L}$ of latex bead conjugate mix $(0.15 \%$ anti-spike -latex bead, $0.1 \%$ or $0.05 \%$ Chicken IgY latex bead in $50 \mathrm{mM}$ borate [pH 8.5]) to the conjugate pad in the LFA. After a 10-minute delay to let the conjugate mix dry, $75 \mu \mathrm{L}$ of sample diluted in $2.5 \%$ BSA in PBST, spike glycoprotein or buffer (2.5\% BSA in PBST or $2.5 \%$ BSA and 1\% IGEPAL in $1 \times$ PBS) was added to the sample pad. Images were acquired 20 minutes after sample addition. Four technical replicates were run for each antibody pair per sample type.

\section{Screening recombinant antigens on LFAs}

LFAs were screened across two rounds using a recombinant spike glycoprotein as the as the antigen target. The first, with the best-available at the time spike antigen (from Sino Biological), at $80 \mathrm{ng} / \mathrm{mL}$. The second round used a different recombinant antigen produced in house was subsequently determined preferable, was also used at a concentration of $80 \mathrm{ng} / \mathrm{mL}$,. A complete list of all pairs screened from all rounds is in Table 1si (suppl. info).

\section{$\underline{\text { Results }}$}

\section{Liquid immunoassay screening}

All of the data generated from screening antibodies using the liquid platform in the following section is publicly accessible. ${ }^{29} \mathrm{~A}$ total of 48 human monoclonal antibodies (AbCellera, 41; Sino Biological, 3; Leinco, 4) were assessed for their performance as capture and detection antibodies for the SARS CoV-2 S glycoprotein using the MSD U-PLEX immunoassay format across 3 rounds of testing. Each well in a 96 well U-PLEX plate can host 10 different capture antibodies in a geometric planar array by assessing ten capture antibodies per well $(960$ per plate) enabled rapid screening of multiple combinations to identify the most promising candidate pairs that would enable sensitive and specific capture and detection of SARS CoV-2.

In the preliminary evaluations, a recombinant $S$ glycoprotein antigen expressed from insect cells (BEI) was used to screen the AbCellera antibodies however, this particular antigen resulted in the generation of very low $\mathrm{ECL}$ signals, at the concentration used. We postulate that as the post-translational modifications that can arise during antigen production will differ between insect cells and mammalian cells, the antigen initially used may have had or lack modifications that made it unsuitable for our study ${ }^{30}$. To identify an antigen most suitable for this work we evaluated 3 recombinant $S$ glycoproteins across a range of dilutions (1000 to $0.24 \mathrm{pg} / \mathrm{mL}$ ) using $\mathrm{AbC5} 25$ and $\mathrm{AbC} 397$ as capture and detector respectively; this pair had generated the strongest $\mathrm{ECL}$ in the preliminary screen. The signal intensities and LOD varied with respect to each of the three antigens used. The 
mammalian cell-derived recombinant $\mathrm{S}$ glycoprotein from Acro Biosystems produced the strongest and more consistent signal as compared to the baculovirus expressed antigens, and the lowest LOD (Figure 1). Thus, this antigen was selected for use as the standard in all antibody screens.

In round 1, 41 antibodies from AbCellera were assessed in both capture and detector format (1681 unique antibody pairings in total) using a low $\mathrm{S}$ glycoprotein antigen concentration of $10 \mathrm{ng} / \mathrm{mL}$ to allow for more stringent down-selection. Table 1 summarizes the Round 1 screening results in a matrixed array for each antibody combination. In the absence of a positive control assay, the ECL values from each array spot in each well were normalized based on the percentile of signal-noise (S-N) in each plate versus the spot with the maximum S-N produced in each plate. A total of 117 (7.0\%) antibody pairs produced at least $25 \%$ of the maximum signal (marked in blue). These pairs, that consisted of 20 capture and 23 detection antibodies, were then further screened in a total of 460 combinations with $S$ antigen in a range of 10,100 and $-1000 \mathrm{ng} / \mathrm{mL}$ to confirm the initial results (Figure 2). The ten antibody pairs that generated highest ECL signals were selected for evaluation in round 2, and included two capture antibodies (AbC447 and AbC525) and five detector antibodies (AbC513, AbC518, AbC459, AbC447 and AbC511). No self-pairing antibodies were identified presumably due to the presence of only single epitope on the recombinant antigen that would limit binding to only one form of the respective labeled antibody.

Figure 1. I Curves demonstrating assay performance of 3 commercially available trimeric $S$ glycoproteins across a range of dilutions when screened via AbC525-AbC397 pair. $\left(\operatorname{LOD}_{\text {Acros Biosystems }}=286 \mathrm{pg} / \mathrm{mL}, L_{\text {SOno Biological }}=768\right.$ $\mathrm{pg} / \mathrm{mL}, \mathrm{LOD}_{\mathrm{BEI}}=19665 \mathrm{pg} / \mathrm{mL}$ ).

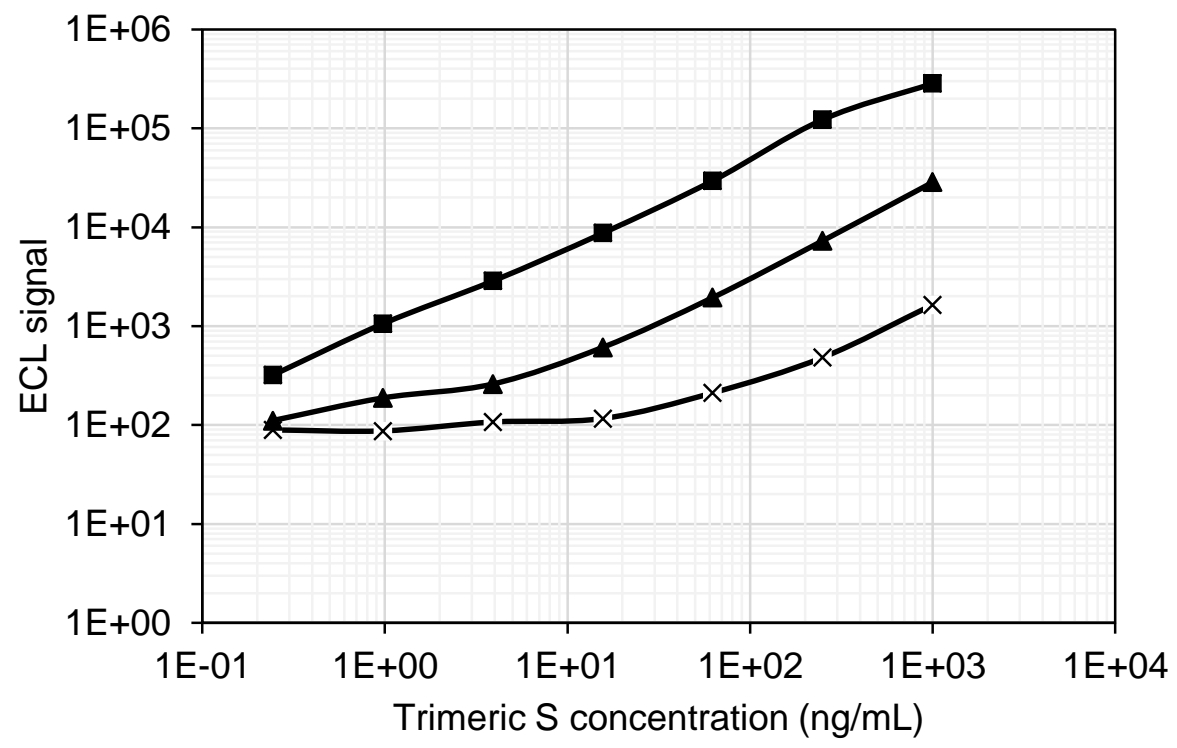

$\rightarrow$-Trimeric S (Acro Biosystems) $\quad-x-$ Trimeric S (BEI Resources) $\rightarrow$ Trimeric S (Sino Biological) 
Table 1. | Performance of the 41 AbCellera antibodies in capture and detector formats in sandwich assays. The color gradient represents pair performance, measured as signal -noise. Darker indicates a pair performed better. Numbers inside the grid are normalized 0-1.0 according to the pairs with lowest and highest S-N. Legend $\square 0.75-1.00, \square 0.50-0.74, \square 0.25-0.49, \square 0.00-0.24$.

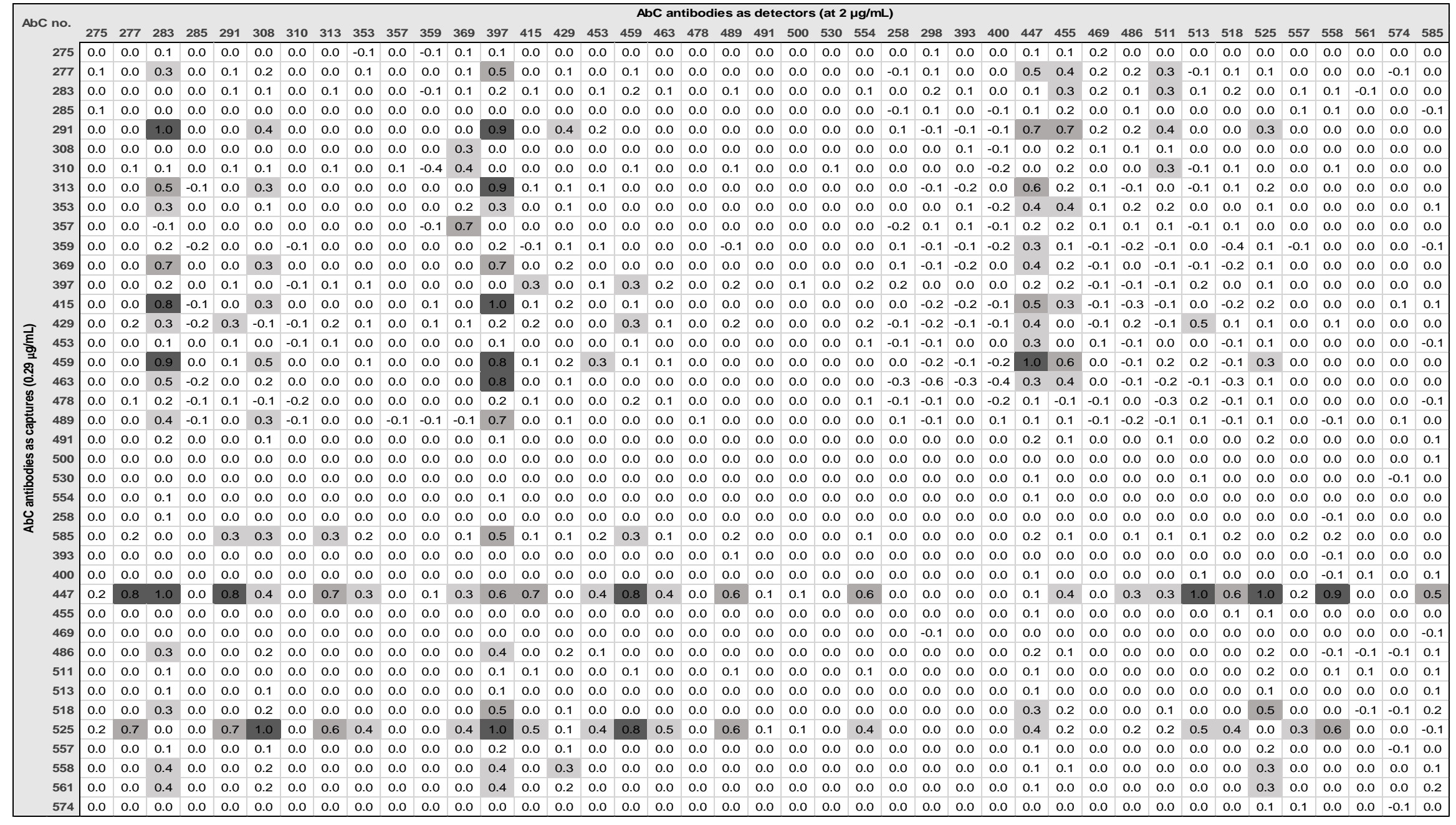


Figure 2. I The 460 AbCellera antibody pairs ranked based on signal intensity of a range of concentrations of the trimeric $S$ glycoprotein antigen. $\mathrm{ECL}$, electrochemiluminescence.

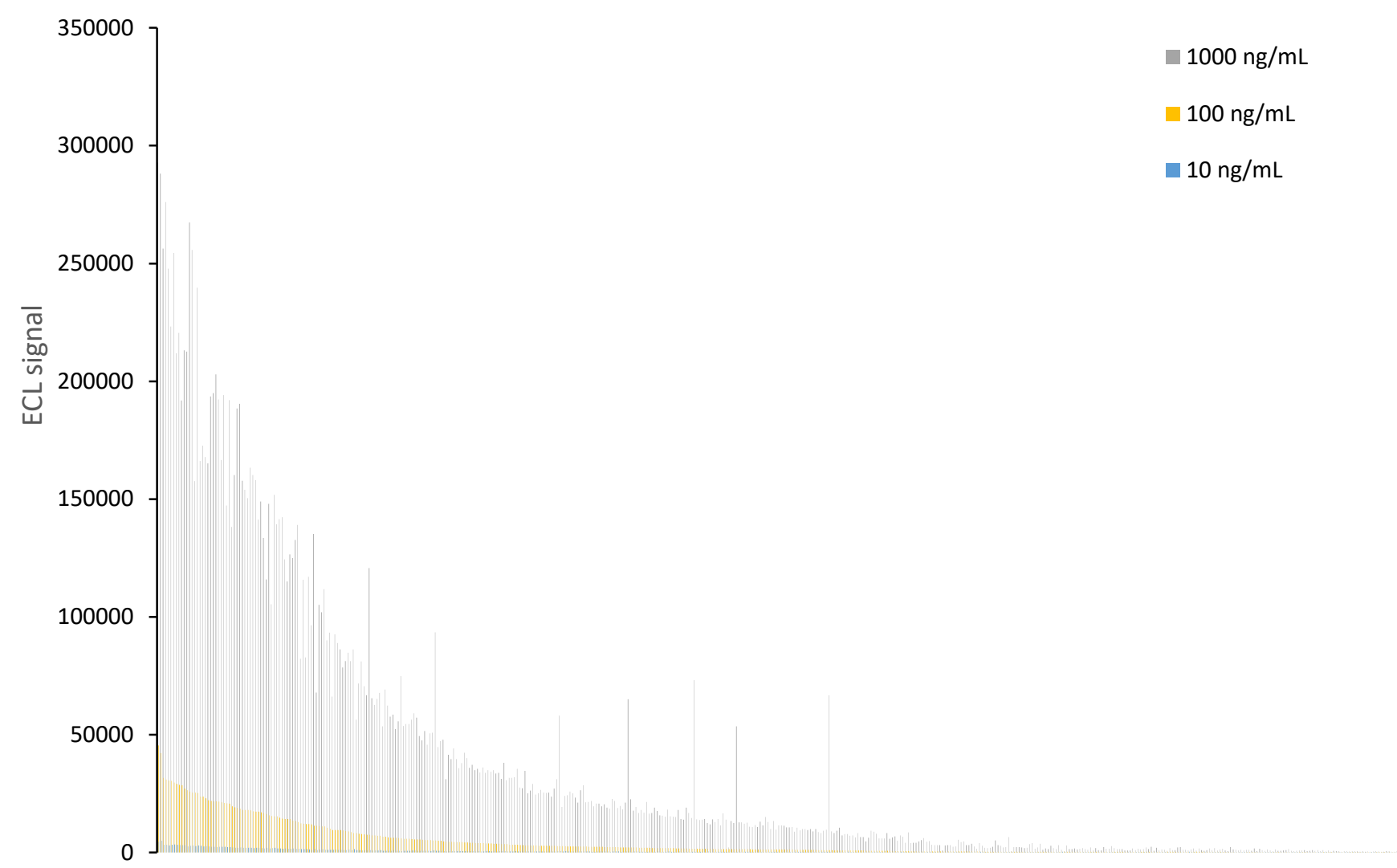

\section{Antibody pairs}

In round 2, the 10 AbCellera optimal antibody pairs were assessed further in a matrix format alongside three antibodies from Sino Biological (MM443, MM57 and D003). Screening with an 8-point standard curve indicated that the Sino Biological antibodies resulted in higher ECL signals and lower LODs than the best AbCellera pair (AbC447/AbC513) (Table 2). Notably the Sino 447/MM43 and 447/D003 pairs exhibited similarly low LODs at 43 and $45 \mathrm{pg} / \mathrm{mL}$ respectively, in addition to the highest ECL signals at when challenged with $\geq 625 \mathrm{ng} / \mathrm{mL}$ of trimeric $S$ antigen. Antibody pairs AbC447/MM43 and AbC447/D003 were then further challenged with a range of concentrations of SARS-CoV-2 virions, both 
detecting down to $80 \mathrm{TCID}_{50} / \mathrm{mL}$ or approximately $4.86 \times 10^{5}$ genome equivalents $/ \mathrm{mL}$, with the AbC447-MM43 pair was determined to have the best performance characteristics at this stage.

Table 2. | Top antibody pairs from rounds 2 and 3 when challenged with $S$ glycoprotein ranked based on their LOD. The electrochemiluminescent (ECL) signal intensity generated with $625 \mathrm{ng} / \mathrm{mL}$ S antigen is also included.

\begin{tabular}{|l|l|c|c|}
\hline Capture Ig & Detector Ig & $\begin{array}{l}\text { ECL signal (625 } \\
\mathrm{ng} / \mathrm{mL} \text { antigen) }\end{array}$ & LOD (pg/mL) \\
\hline \multicolumn{3}{|l|}{} \\
\hline Round 2 & \multicolumn{3}{|l|}{} \\
\hline AbC447 & MM43 & 801003 & 43 \\
\hline AbC447 & D003 & 871186 & 45 \\
\hline AbC447 & AbC513 & 215672 & 71 \\
\hline D003 & MM43 & 168029 & 94 \\
\hline MM43 & AbC447 & 199763 & 174 \\
\hline Round 3 & \multicolumn{3}{|}{} \\
\hline L2381 & MM43 & 1097669 & 3 \\
\hline L2355 & L2215 & 2200950 & 4 \\
\hline L2838 & L2215 & 2580454 & 6 \\
\hline L2381 & L2215 & 1760625 & 7 \\
\hline L2355 & MM43 & 1568224 & 8 \\
\hline AbC447 & MM43 & 1145169 & 37 \\
\hline
\end{tabular}

In round 3, four antibodies procured from Leinco (L2215, L2355, L2381 and L2838) screened with the 6 top antibody candidates identified from round 2 (D003, MM42, AbC447, and AbC513) and round 1 (AbC353 and AbC525). When used either as a capture or detector, the Leinco antibodies typically generated higher ECL signal and lower LODs than previously observed (Table 2), many with the LOD generally 5-10 times lower than for the best performing antibody in round 2. The L2381/MM43 and L2355/L2215 combinations had near identical LODs at 3 and 4 $\mathrm{pg} / \mathrm{mL}$ respectively, with $\mathrm{L} 2355 / \mathrm{L} 2215$ were selected for further study due to greater affinity to the target as indicated by significantly higher $\mathrm{ECL}$ signal when challenged with S antigen at $625 \mathrm{ng} / \mathrm{mL}$ (Table 2). The antibody pair L2355/L2215 was challenged with a titered SARS-CoV-2 (BEI), resulting in the generation of a dose-dependent curve (Figure 3) with an estimated LOD of $2 \mathrm{TCID}_{50} / \mathrm{mL}$ virions or $7.4 \times 10^{3}$ genome equivalents/mL. 
Figure 3. |The detection of serial dilutions of inactivated SARS-CoV-2 using the L2355 (capture)/L2215 (detector) antibody pair.

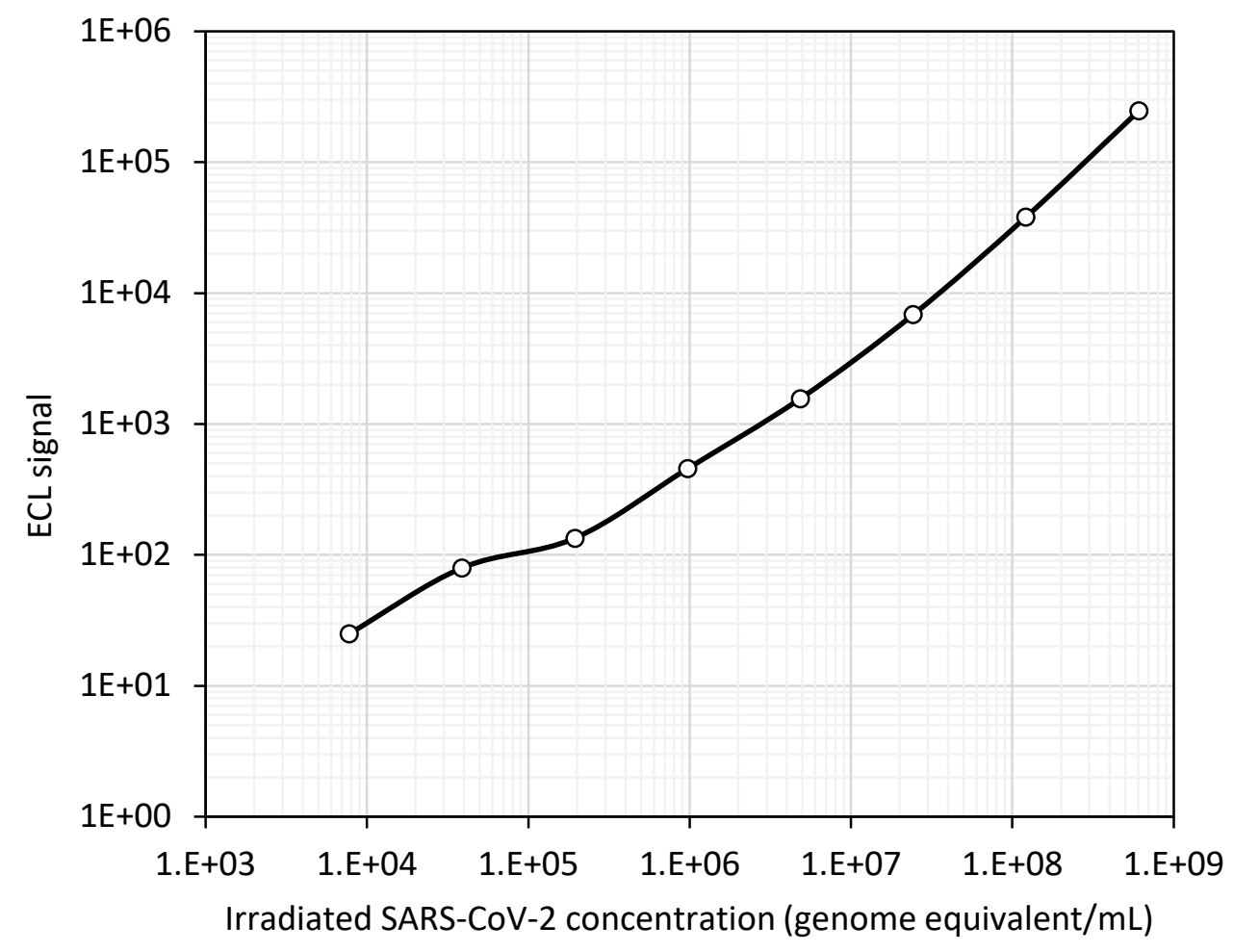

To demonstrate assay performance of the L2355/L2215 antibody pair with clinical samples, a panel of fifty-three de-identified clinical samples, comprising of 20 COVID19-negatives and 33 COVID19-positives were used to challenge the assay. Of these, 44 of the 53 samples were correctly identified as either positive or negative (Table 5). The viral load of the specimen was important as nine positive samples, each with a cycle threshold of $>29.5$, were incorrectly scored as negative. This was likely in part due to dilution of the sample as each nasopharyngeal swab was collected in $3 \mathrm{mLs}$ of viral transport medium. Overall the assay had a sensitivity and specificity of $73 \%$ and $100 \%$ respectively (Table 5 ) when compared to the RT-PCR results. 
Table 5. | Performance characteristics of the L2355 (capture)/L2215 (detector) pairing relative to qRT-PCR when challenged with 53 clinical specimens.

\begin{tabular}{|l|ccc|cc|}
\hline & MSD Positive & MSD Negative & Total & Sensitivity (\%) & Specificity (\%) \\
\hline RT PCR Positive & 24 & 9 & 33 & 73 & 100 \\
RT PCR Negative & 0 & 20 & 20 & & \\
Total & 24 & 29 & 53 & & \\
\hline
\end{tabular}

\section{Specificity screening of top candidate pairs with other species of coronavirus in liquid immunoassays}

The cross-reactivity of the antibody pairs from rounds 2 and 3 (Table 2) were also evaluated by challenging them with alpha- and betacoronavirus isolates including inactivated MERS and SARS virions and human coronaviruses OC43 and 229E cell culture lysates at concentrations equivalent to $10^{4} \mathrm{TCID}_{50} / \mathrm{mL}$ or $10^{4} \mathrm{PFU} / \mathrm{mL}$. None of the ten antibody pairs showed any cross-reactivity with other human CoV indicating a high specificity towards SARS-CoV-2.

\section{Candidate screening via lateral flow assays.}

The candidate antibodies were also evaluated in the LFA format in two rounds of screens, to assess if the performance of the candidate antibodies varied between the liquid and LFA test formats. A total of 8 antibodies (AbC131 from AbCellera, D003 from Sino Biological and 6 other antibodies from Sino Biological and Creative Diagnostics) were evaluated in Round 1 on LFAs in an $8 \times 8$ matrix (64 unique pairs, see Table 1si). For each pair, one antibody was striped on nitrocellulose as a test line (the "capture" antibody) and the other was coupled to latex nanoparticles using EDC/NHS chemistry (the "detector" antibody). The results of the first round are given in Figure 5(A). The positive control used round 1 was $80 \mathrm{ng} / \mathrm{mL} \mathrm{S} \mathrm{glycoprotein} \mathrm{from} \mathrm{Sino} \mathrm{Biological,} \mathrm{selected} \mathrm{due} \mathrm{the} \mathrm{presence} \mathrm{of} \mathrm{both} \mathrm{the} \mathrm{S1} \mathrm{and} \mathrm{S2} \mathrm{domains} \mathrm{of} \mathrm{the} \mathrm{native} \mathrm{spike}$ trimer. The negative control was $2.5 \%$ BSA in PBST. 
Figure 5. | Performance of 621 individual antibody pairs in 2 rounds of screening on the LFA format as a function of signal / noise and signal noise. Line intensities are shown as scatter plots for round 1 (A) and round 2 (B). Antibody pairs performing in the top 5 [for average rank by $\mathrm{S} / \mathrm{N}$ and S-N] are overlaid with a semi-transparent box and numbered by their index (full list in Table 2si). "Sino Bio" antigen was sourced from Sino Biological and "in-house spike" recombinant antigen was produced in and purified at Global Health Labs.

\section{A Round 1 (80 ng/mL Sino Bio spike)}

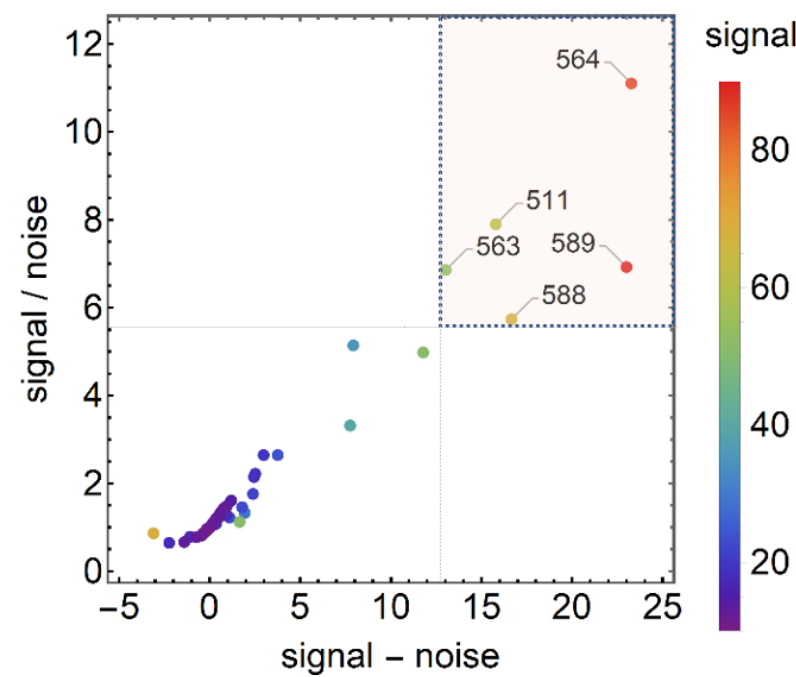

\section{B Round $2(80 \mathrm{ng} / \mathrm{mL}$ in-house spike)}

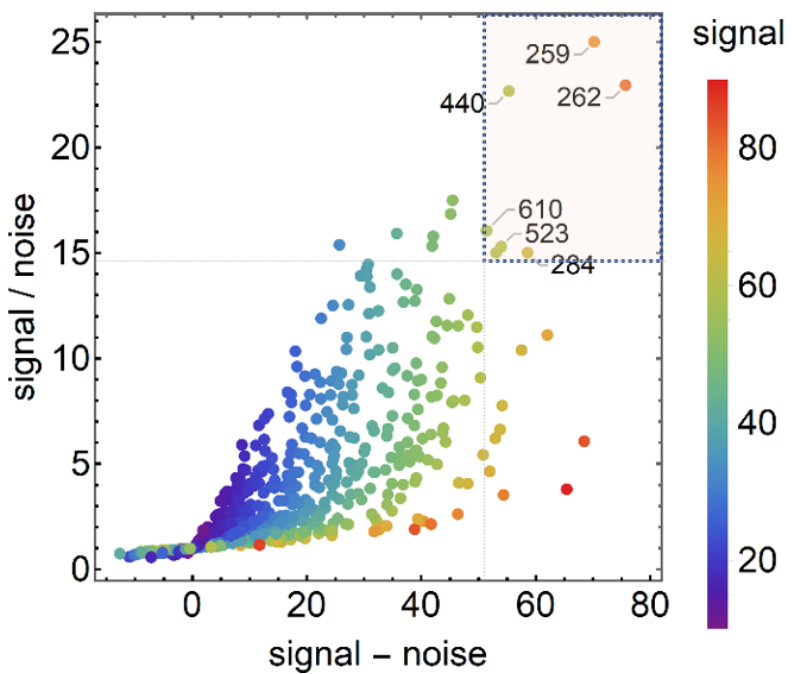

After the first round, the best five pairs were D003/D002, D004/D002, D001/D004, D004/D001 and D003/D001 (index 564, 589, 511, 568, and 563 , Table 3). Each of the top pairs from round 1 consisted exclusively of antibodies from Sino Biological, which was unsurprising considering recombinant antigen choice and the fact that most antibodies screened were from Sino Biological. As with the liquid immunoassay screen, selfpairs did not perform well, as expected, a consequence of the monomeric recombinant antigen likely containing a single copy of the target sequence. However, we would expect self-pairs to do better against the native antigen in clinical samples because it is trimeric. After round 1, 57 anti-S pairs were eliminated and the top seven pairs carried to round 2, along with 22 new antibodies. These new antibodies included the 12 -top performing AbCellera antibodies from round 1 liquid immunoassay screen, MM43 from Sino Biological, and 9 antibodies from Leinco Technologies, including the 4 antibodies already screened with liquid immunoassay (Figure 1si). 
Table 3. | Antibody pairs in the top five for both the signal to noise ratio $[\mathrm{S} / \mathrm{N}]$ and signal minus noise [S-N] are ranked according to the round in which they were tested. Table 2si (supp. info) contains a complete list of all pairs screened.

\begin{tabular}{|l|l|l|c|c|}
\hline \multirow{2}{*}{ Index } & \multirow{2}{*}{ Capture } & \multirow{2}{*}{ Detector } & \multicolumn{2}{|l|}{ Average Rank } \\
\cline { 3 - 5 } & & & RD. 1 & RD. 2 \\
\hline \multicolumn{5}{|l|}{ Round 1 Top 5 Performers } \\
\hline 564 & D003 & D002 & 1 & 302 \\
\hline 589 & D004 & D002 & 2.5 & - \\
\hline 511 & D001 & D004 & 3 & - \\
\hline 588 & D004 & D001 & 4 & - \\
\hline 563 & D003 & D001 & 4.5 & 156.5 \\
\hline \multicolumn{5}{|l|}{} \\
\hline 259 & AbC459 & L2355 & - & 1.5 \\
\hline 262 & AbC459 & D001 & - & 1.5 \\
\hline 440 & L2355 & AbC459 & - & 5.5 \\
\hline 284 & AbC525 & L2355 & - & 9 \\
\hline 523 & D002 & AbC459 & - & 11 \\
\hline
\end{tabular}

The grid for round 2 was larger at $26 \times 26$ (616 pairs), however limited access to material meant 60 pairs were ultimately excluded (Figure 1 si). Results from round 2 are shown in a scatterplot in Figure $5(B)$. The positive control used here was a trimeric spike glycoprotein produced inhouse, considered superior to the recombinant form due to its ability to better mimic the protein folding seen in native structures. The negative control used was $2.5 \%$ BSA in PBST. Based on S/N and S-N metrics, the five best performing antibody indices from round 2 were 259, 262, 440, 284,523 , and 610 (Table 3).

\section{Discussion}

In this paper, we present the screening of a panel of antibodies targeting the S glycoprotein of SARS Cov- 2 to identify candidate capture and detector pairs that may be suitable for development of LFA antigen detection assays. We gained access to a large private collection but with limited access to sufficient materials resulting in some antibodies being screened in one assay and not the other. Commercially available antibodies were typically screened on both formats. A key to this work is the availability of a good native antigen proxy, and as antigen sources can vary considerably, it is important to assess them prior to commencing work. Using the highly sensitive MSD immunoassay platform we are able to achieve an analytical sensitivity in the range of to $7.4 \times 10^{3}$ genomic copies $/ \mathrm{mL}$ and a specificity of $100 \%$ when using a limited specimen panel. The TPP for a test for diagnosis or confirmation of acute or subacute SARS-CoV-2 infection, suitable for low or high-volume needs notes a 
sensitivity of under 1000 copies which this test does not currently meet. However, the intent of this project was to screen antibodies that have optimal potential for implementation in LFAs, and not to develop a diagnostic assay. If necessary, the platform can use a further enhance signal format not used here, the S-PLEX which MSD claim can further improve sensitivity by 10 - 100X or into the lower femtogram range. While the S glycoprotein is less abundant that the $\mathrm{N}$ protein, there may be utility for combining $\mathrm{S}$ as a target to create highly sensitive multiplex immunoassays, with its additional distinct epitopes enabling improved accuracy, especially at lower limits of detection ${ }^{31 ; 32}$.

The liquid assays identified pairs that gave an analytical sensitivity to the $S$ antigen into the low picogram range, a tenfold improvement over previous $\mathrm{N}$ immunoassays reported for SARS but the ECL detection feature of the MSD device does also offer greater sensitivity over traditional colorimetric detection employed by most enzyme immunoassay methods ${ }^{33 ; 34}$. Interestingly, the assay format had a distinct effect on the optimal candidate pairs identified. The L2135 clone was the best antibody in either format and as both capture and detector. In contrast, no AbCellera antibodies showed good performance in the liquid assay, though in the LFA format AbC459 was present as capture or detector in 4/5 top pairs. The use of a different source of recombinant antigen may have played a role in this as we did observe some difference in binding using mammalian recombinant sources of antigen. This finding serves as an insight to LFA developers wherein screening of all antibodies should be performed on nitrocellulose rather than using traditional liquid immunoassays. The best antibodies candidates screened in the liquid format appeared to be highly specific to SARS-CoV-2 as they were not reactive with SARS, MERS and OC43 HCoVs that are in the same genus as SARSCoV-2 ${ }^{35 ; 36}$. While we did not have access to HKU1, another beta-CoV species associated with respiratory illness, we do expect it is unlikely to be reactive as the other more closely related beta-CoVs screened were non-reactive.

On the LFA platform, the best pairs, as measured by $\mathrm{S} / \mathrm{N}$ and $\mathrm{S}-\mathrm{N}$, were from a combination of vendors (e.g. AbCellera, Leinco, and Sino Biological), likely because these high-affinity antibodies were raised via unique processes and therefore recognize different epitopes on the antigen.

Interestingly, the liquid and LFA formats did identify very different optimal pairs for the detection of the $S$ antigen. Restricted resources meant that entire antibody sets could not be fully evaluated on both platforms but it was evident that some pairs were better suited to one format over the other. In the liquid format, none of the AbCellera antibodies were in the top candidates as either capture or detector by round 3 but with the LFA, AbC459 and AbC525 were represented in several optimal pairings (Table 2). With the Sino Biological antibodies a similar trend was noted wherein no candidates shone with the liquid immunoassay format while the LFA had two, D001 and D002 (Tables 2 and 3). Antibodies from Leinco were highly represented in the optimal liquid assay design with each of the top five pairs having at least one Leinco antibody in the pairing. By contrast, with the top five candidates in the LFA format, three pairs used a single Leinco antibody, L2355, either as capture or detector, though in combination with differing antibodies to the liquid format.

Our goal is to qualify reagents and methods that are publicly available to any developer who sees value in their use, removing the need for them to invest time and resources on antibodies with little or no potential. Further work is ongoing with our groups to develop a POC LFA with the potential for manufacturing at scale. An advantage of using recombinant antibodies like those from AbCellera and Leinco is that the variable antibody region of single antigen-specific memory B cells derived from convalescent patients is cloned into an expression vector enabling cost 
efficient scaled production of antibodies. In addition, this work uses recombinant IgG antibodies which are monomeric; with the possibility of manipulating the same variable region sequences to create recombinant IgM type antibodies, decameric forms of which may improve capture and/or detector efficiency leading to more effective rapid antigen assays for COVID-19 diagnosis.

\section{Acknowledgements}

This work was funded via a grant (INV-016821) awarded by the Bill and Melinda Gates Foundation (https://www.gatesfoundation.org/) awarded to DSB. These funders did not have any additional role in the study design, data collection and analysis, decision to publish, or preparation of the manuscript. Funding was also provided by The Global Good Fund and Global Health Labs, a nonprofit organization created by Gates Ventures and the Gates Foundation to develop innovative solutions to address unmet needs in primary health care centers and the last mile. AbCellera was funded by the US Department of Defense, Defense Advanced Research Projects Agency - Pandemic Prevention Platform. Agreement no. D18AC0000.

\section{Disclaimers}

Other than funding the PATH authors salaries, the BMGF did not have any additional role in the study design, data collection and analysis, decision to publish, or preparation of the manuscript. This research was, in part, funded by the U.S. Government. The views and conclusions contained in this document are those of the authors and should not be interpreted as representing the official policies, either expressed or implied, of the U.S. Government.

\section{Competing interests}

$\mathrm{BCB}, \mathrm{LK}, \mathrm{KH}, \mathrm{VP}$ and $\mathrm{YH}$ are employees of AbCellera biologics.

\section{Reference List}

1. Huang, C.; Wang, Y.; Li, X.; Ren, L.; Zhao, J.; Hu, Y.; Zhang, L.; Fan, G.; Xu, J.; Gu, X.; Cheng, Z.; Yu, T.; Xia, J.; Wei, Y.; Wu, W.; Xie, X.; Yin, W.; Li, H.; Liu, M.; Xiao, Y.; Gao, H.; Guo, L.; Xie, J.; Wang, G.; Jiang, R.; Gao, Z.; Jin, Q.; Wang, J.; Cao, B. Lancet 2020, 395, 497-506.

2. WHO. Coronavirus disease (COVID-19) Situation Reports. 2020. Ref Type: Report

3. Cui, J.; Li, F.; Shi, Z. L. Nat.Rev.Microbiol. 2019, 17, 181-92. 
4. Park, W. B.; Kwon, N. J.; Choi, S. J.; Kang, C. K.; Choe, P. G.; Kim, J. Y.; Yun, J.; Lee, G. W.; Seong, M. W.; Kim, N. J.; Seo, J. S.; Oh, M. D. J.Korean Med.Sci. 2020, 35, e84.

5. Yan, R.; Zhang, Y.; Li, Y.; Xia, L.; Guo, Y.; Zhou, Q. Science 2020, 367, 1444-48.

6. Zheng, M.; Song, L. Cell Mol.Immunol. 2020, 17, 536-38.

7. Premkumar, L.; Segovia-Chumbez, B.; Jadi, R.; Martinez, D. R.; Raut, R.; Markmann, A.; Cornaby, C.; Bartelt, L.; Weiss, S.; Park, Y.; Edwards, C. E.; Weimer, E.; Scherer, E. M.; Rouphael, N.; Edupuganti, S.; Weiskopf, D.; Tse, L. V.; Hou, Y. J.; Margolis, D.; Sette, A.; Collins, M. H.; Schmitz, J.; Baric, R. S.; de Silva, A. M. Sci.Immunol. 2020, 5.

8. Patel, R.; Babady, E.; Theel, E. S.; Storch, G. A.; Pinsky, B. A.; St, G. K.; Smith, T. C.; Bertuzzi, S. mBio. 2020, 11.

9. Dramé, M.; Tabue, M. T.; Proye, E.; Hequet, F.; Hentzien, M.; Kanagaratnam, L.; Godaert, L. J.Med.Virol. 2020.

10. Kucirka, L. M.; Lauer, S. A.; Laeyendecker, O.; Boon, D.; Lessler, J. Ann.Intern.Med. 2020, 173, 262-67.

11. US food and Drug Administration. In Vitro Diagnostics EUAs. 2020. 7-14-2020.

12. Gorzalski, A. J.; Tian, H.; Laverdure, C.; Morzunov, S.; Verma, S. C.; VanHooser, S.; Pandori, M. W. J.Clin.Virol. 2020, $129,104501$.

13. Lieberman, J. A.; Pepper, G.; Naccache, S. N.; Huang, M. L.; Jerome, K. R.; Greninger, A. L. J.Clin.Microbiol. 2020.

14. Pujadas, E.; Ibeh, N.; Hernandez, M. M.; Waluszko, A.; Sidorenko, T.; Flores, V.; Shiffrin, B.; Chiu, N.; Young-Francois, A.; Nowak, M. D.; Paniz-Mondolfi, A. E.; Sordillo, E. M.; Cordon-Cardo, C.; Houldsworth, J.; Gitman, M. R. J.Med.Virol. 2020.

15. Kohmer, N.; Westhaus, S.; Rühl, C.; Ciesek, S.; Rabenau, H. F. J.Clin.Virol. 2020, 129, 104480.

16. ASM Advocacy. ASM Expresses Concern about Coronavirus Test Reagent Shortages. 4-20-2020. American Society for Microbiology.

17. Bong, C. L.; Brasher, C.; Chikumba, E.; McDougall, R.; Mellin-Olsen, J.; Enright, A. Anesth.Analg. 2020, 131, 86-92.

18. Niemz, A.; Ferguson, T. M.; Boyle, D. S. Trends Biotechnol. 2011, 29, 240-50.

19. Guo, L.; Ren, L.; Yang, S.; Xiao, M.; Chang, D.; Yang, F.; la Cruz, C. S.; Wang, Y.; Wu, C.; Xiao, Y.; Zhang, L.; Han, L.; Dang, S.; Xu, Y.; Yang, Q. W.; Xu, S. Y.; Zhu, H. D.; Xu, Y. C.; Jin, Q.; Sharma, L.; Wang, L.; Wang, J. Clin.Infect.Dis. 2020, 71, 778-85. 
20. Li, R.; Pei, S.; Chen, B.; Song, Y.; Zhang, T.; Yang, W.; Shaman, J. Science 2020, 368, 489-93.

21. Figueroa, C.; Johnson, C.; Ford, N.; Sands, A.; Dalal, S.; Meurant, R.; Prat, I.; Hatzold, K.; Urassa, W.; Baggaley, R. Lancet HIV. 2018, 5, e277-e290.

22. Jang, I. K.; Das, S.; Barney, R. S.; Peck, R. B.; Rashid, A.; Proux, S.; Arinaitwe, E.; Rek, J.; Murphy, M.; Bowers, K.; Boadi, S.; Watson, J.; Nosten, F.; Greenhouse, B.; Chiodini, P. L.; Domingo, G. J. Malar.J. 2018, 17, 403.

23. Molesworth, A. M.; Ndhlovu, R.; Banda, E.; Saul, J.; Ngwira, B.; Glynn, J. R.; Crampin, A. C.; French, N. J.Acquir.Immune.Defic.Syndr. 2010, $55,625-30$.

24. WHO. COVID-19 Target product profiles for priority diagnostics to support response to the COVID-19 pandemic v-0.1. 1-41. 7-31-2020. Geneva, World Health Organization.

25. Grant, B. D.; Anderson, C. E.; Williford, J. R.; Alonzo, L. F.; Glukhova, V. A.; Boyle, D. S.; Weigl, B. H.; Nichols, K. P. Anal.Chem. 2020

26. Cate, D.; Hsieh, H.; Glukhova, V.; Bishop, J. D.; Hermansky, G. H.; Barrios-Lopez, B.; Grant, B. D.; Anderson, C. E.; Spencer, E.; Kuhn, S.; Gallagher, R.; Rivera, R.; Bennet, C.; Byrnes, S. A.; Connelly, J. T.; Dewan, P. K.; Boyle, D. S.; Weigl, B. H.; Nicols, K. P. CHEMRxiv 2020.

27. Huynh, T., Cate, D. M., Nichols, K. P., Weigl, B. H., Anderson, C. E., Gasperino, D. J., Harston, S. P., Hsieh, H. V., Marzan, R., Williford, J. R., Oncina, C. I., and Glukhova, V. A. Robotic System for the Development Lateral Flow Assays. IEEE Global Humanitarian Technology Conference. 2019. Institute of Electrical and Electronics Engineers Inc.

28. Washington COVID-19 Biorepository. 8-27-2020.

29. Cantera, J. L. Screening data for "Screening antibodies raised against the spike glycoprotein of SARS-CoV-2 to support the development of rapid antigen assays". 2020. Harvard Dataverse.

30. McKenzie, E. A.; Abbott, W. M. Methods 2018, 147, 40-49.

31. Che, X. Y.; Qiu, L. W.; Pan, Y. X.; Wen, K.; Hao, W.; Zhang, L. Y.; Wang, Y. D.; Liao, Z. Y.; Hua, X.; Cheng, V. C.; Yuen, K. Y. J.Clin.Microbiol. 2004, 42, 2629-35.

32. Leung, D. T.; Tam, F. C.; Ma, C. H.; Chan, P. K.; Cheung, J. L.; Niu, H.; Tam, J. S.; Lim, P. L. J.Infect.Dis. 2004, 190, 379-86. 
33. Che, X. Y.; Qiu, L. W.; Pan, Y. X.; Wen, K.; Hao, W.; Zhang, L. Y.; Wang, Y. D.; Liao, Z. Y.; Hua, X.; Cheng, V. C.; Yuen, K. Y. J.Clin.Microbiol. 2004, 42, 2629-35.

34. He, Q.; Du, Q.; Lau, S.; Manopo, I.; Lu, L.; Chan, S. W.; Fenner, B. J.; Kwang, J. J.Virol.Methods 2005, 127, 46-53.

35. Lau, S. K.; Li, K. S.; Tsang, A. K.; Lam, C. S.; Ahmed, S.; Chen, H.; Chan, K. H.; Woo, P. C.; Yuen, K. Y. J.Virol. 2013, 87, 8638-50.

36. Mesel-Lemoine, M.; Millet, J.; Vidalain, P. O.; Law, H.; Vabret, A.; Lorin, V.; Escriou, N.; Albert, M. L.; Nal, B.; Tangy, F. J.Virol. 2012, 86, 7577-87. 


\section{Supplementary Information}

Figure 1si | Heat map of spike protein antibody pair performance in LFAs for round 2. Gray squares indicate pairs that were not tested. The color gradient represents pair performance, measured as signal - noise. Darker indicates a pair performed better. Numbers inside the grid are normalized 0-100 according to the pairs with lowest and highest S-N.

\begin{tabular}{|c|c|c|c|c|c|c|c|c|c|c|c|c|c|c|c|c|c|c|c|c|c|c|c|c|}
\hline B-MM43 & & & & & & & & & & & & & & 28 & & & & & & 42 & & & & \\
\hline SB- & 54 & 33 & 54 & 41 & 28 & 34 & 38 & 18 & 42 & 42 & 45 & 55 & 27 & 33 & 51 & 37 & 35 & 49 & 43 & 46 & 46 & 16 & 24 & 62 \\
\hline SB-D002 & 65 & 37 & 55 & 34 & 26 & 48 & 47 & 12 & 51 & 37 & 67 & 71 & 59 & 20 & 50 & 34 & 20 & 43 & 29 & 451 & 19 & 21 & & \\
\hline SB-D001 & 62 & 42 & 49 & 29 & 39 & 49 & 63 & 36 & 58 & 45 & 100 & 92 & 42 & 19 & 40 & 34 & 21 & 49 & 40 & 491 & 17 & 33 & & \\
\hline L-2838 & 69 & 49 & 62 & 53 & 57 & 69 & 56 & 32 & 53 & 14 & 76 & 74 & 62 & 55 & 52 & 12 & 51 & 17 & 17 & 175 & 53 & 39 & 64 & 66 \\
\hline L-2381 & 63 & 40 & 62 & 38 & 38 & 49 & 59 & 25 & 54 & 16 & 71 & 72 & 58 & 39 & 39 & 15 & 43 & 21 & 17 & 205 & 52 & 40 & 65 & 58 \\
\hline L-2355 & 74 & 49 & 66 & 43 & 44 & 55 & 64 & 30 & 56 & 17 & 94 & 81 & 88 & 39 & 76 & 13 & 42 & 21 & 20 & 205 & 54 & 42 & 59 & 73 \\
\hline L-2215 & 40 & 26 & 35 & 24 & 29 & 34 & 32 & 16 & 27 & 35 & 45 & 37 & 59 & 19 & 45 & 28 & 15 & 34 & 27 & 362 & 25 & 24 & 46 & 26 \\
\hline L-2197 & 30 & 20 & 31 & 34 & 20 & 20 & 29 & 13 & 37 & 22 & 31 & 32 & 5 & 33 & 9 & 4 & 20 & 45 & 40 & 503 & 33 & 23 & 57 & 50 \\
\hline $\mathrm{L}-2165$ & & & & & & & & & & 11 & 35 & 17 & 12 & 19 & 15 & 20 & & & 18 & 171 & 19 & & & \\
\hline $\mathrm{L}-2146$ & 19 & 21 & 24 & 20 & 23 & 19 & 19 & 16 & 22 & 22 & 30 & 25 & 42 & 11 & 16 & 31 & 16 & 27 & 27 & 282 & 21 & 22 & 34 & 25 \\
\hline$L-2143$ & 47 & 31 & 35 & 34 & 23 & 30 & 35 & 22 & 43 & 55 & 50 & 54 & 13 & 55 & 28 & 42 & 48 & 66 & 63 & 60 & & 39 & & 71 \\
\hline $\mathrm{L}-2136$ & 12 & 23 & 25 & 20 & 19 & 23 & 34 & 22 & 26 & 20 & 43 & 44 & 37 & 21 & 20 & 17 & 16 & 29 & 29 & 34 & & 23 & & 22 \\
\hline $\mathrm{AbC}-525$ & 13 & 11 & 17 & 20 & 17 & 17 & 13 & 10 & 38 & 45 & 20 & 13 & 37 & 34 & 33 & 33 & 27 & 50 & 43 & 433 & 33 & 22 & 39 & 48 \\
\hline$A b C-459$ & 18 & 20 & 16 & 27 & 26 & 13 & 11 & 39 & 42 & 59 & 19 & 36 & 67 & 57 & 39 & 64 & 62 & 77 & 79 & 857 & 75 & 44 & 65 & 68 \\
\hline $\mathrm{AbC}-447$ & 46 & 25 & 46 & 24 & 25 & 28 & 47 & 26 & 31 & 11 & 42 & 45 & 37 & 25 & 24 & 13 & 34 & 17 & 15 & 16 & & 25 & & 32 \\
\hline $\mathrm{AbC}-429$ & 38 & 25 & 30 & 16 & 24 & 23 & 19 & 20 & 17 & 50 & 43 & 60 & 26 & 30 & 24 & 35 & 36 & 53 & 47 & 532 & 27 & 34 & 58 & 53 \\
\hline $\mathrm{AbC}-415$ & & & & & & & & & & & & & & 8 & & & 30 & 26 & 53 & 36 & & 19 & & \\
\hline $\mathrm{AbC}-397$ & 9 & 10 & 13 & 11 & 16 & 14 & 18 & 15 & 11 & 19 & 16 & 13 & 14 & 20 & 4 & 17 & 21 & 6 & 16 & 151 & 14 & 14 & 14 & 8 \\
\hline$A b C-353$ & 2 & 18 & 15 & 29 & 21 & 13 & 14 & 23 & 25 & 39 & 16 & 10 & 5 & 34 & 6 & 30 & 23 & 19 & 32 & 362 & 24 & 18 & 39 & 18 \\
\hline $\mathrm{AbC}-313$ & 20 & 22 & 14 & 24 & 22 & 16 & 16 & 23 & 35 & 57 & 14 & 21 & 37 & 31 & 30 & 41 & 42 & 54 & 73 & 643 & 36 & 32 & 60 & 75 \\
\hline$A b C-310$ & 19 & 18 & 26 & 13 & 11 & 23 & 20 & 25 & 18 & 272 & 27 & 28 & 3 & 20 & 11 & 16 & 23 & 33 & 31 & 181 & 13 & 18 & 28 & 14 \\
\hline $\mathrm{AbC}-308$ & 44 & 24 & 28 & 15 & 21 & 22 & 33 & 20 & 19 & 47 & 48 & 50 & 32 & 37 & 32 & 34 & 43 & 59 & 57 & 622 & 24 & 28 & 57 & 58 \\
\hline $\mathrm{AbC}-291$ & 16 & 22 & 15 & 21 & 23 & 15 & 16 & 32 & 46 & 592 & 25 & 7 & 51 & 28 & 17 & 40 & 45 & 63 & 59 & 583 & 37 & 42 & 59 & 67 \\
\hline$A b C-283$ & 28 & 8 & 18 & 15 & 13 & 17 & 21 & 14 & 15 & 272 & 24 & 15 & 22 & 19 & 19 & 25 & 22 & 29 & 34 & 392 & 22 & 27 & 42 & 20 \\
\hline$A b C-277$ & 4 & 20 & 23 & 14 & 18 & 17 & 0 & 19 & 21 & 312 & 22 & 16 & 10 & 12 & 24 & 11 & 31 & 41 & 30 & 312 & 24 & 31 & 50 & 28 \\
\hline
\end{tabular}

normalized

performance

$(\mathrm{S}-\mathrm{N})$

100

90

80

70

60

50

40

30

20

$-10$

0

not tested 
Table 1si | Vendor and other data for the anti-S glycoproteins antibodies screened via liquid and/or lateral flow immunoassay formats.

\begin{tabular}{|c|c|c|c|c|c|c|c|c|c|}
\hline Vendor & Antibody name & Clone & Target region & $\begin{array}{l}\text { Catalog / } \\
\text { reference no. }\end{array}$ & Host & Isotype & Immunogen & $\begin{array}{l}\text { Liquid } \\
\text { immunoassay } \\
\text { tested? }\end{array}$ & $\begin{array}{l}\text { Lateral flow } \\
\text { assay tested? }\end{array}$ \\
\hline AbCellera & $\mathrm{AbC} 275$ & 275 & S2 & 63974.1.a & Humanized & $\lg G 1$ & trimeric spike & $Y$ & $N$ \\
\hline AbCellera & $\mathrm{AbC} 277$ & 277 & S2 & 63997.1.a & Humanized & $\operatorname{lgG1}$ & trimeric spike & $Y$ & $Y$ \\
\hline AbCellera & $\mathrm{AbC} 283$ & 283 & S2 & 63980.1.a & Humanized & $\operatorname{lgG1}$ & trimeric spike & $Y$ & $Y$ \\
\hline AbCellera & $\mathrm{AbC} 285$ & 285 & S1 & 63983.1.a & Humanized & $\operatorname{lgG1}$ & trimeric spike & $Y$ & $\mathrm{~N}$ \\
\hline AbCellera & AbC291 & 291 & S2 & 63986.1.a & Humanized & $\operatorname{lgG1}$ & trimeric spike & $Y$ & $Y$ \\
\hline AbCellera & AbC308 & 308 & S2 & 63992.1.a & Humanized & $\operatorname{lgG1}$ & trimeric spike & $Y$ & $Y$ \\
\hline AbCellera & $\mathrm{AbC} 310$ & 310 & undetermined & 63997.1.a & Humanized & $\operatorname{lgG1}$ & trimeric spike & $Y$ & $Y$ \\
\hline AbCellera & $\mathrm{AbC} 313$ & 313 & S2 & 64000.1.a & Humanized & $\operatorname{lgG1}$ & trimeric spike & $Y$ & $Y$ \\
\hline AbCellera & AbC353 & 353 & S2 & 64003.1.a & Humanized & $\operatorname{lgG1}$ & trimeric spike & $\mathrm{Y}$ & $Y$ \\
\hline AbCellera & $\mathrm{AbC} 357$ & 357 & undetermined & 64006.1.a & Humanized & $\operatorname{lgG} 1$ & trimeric spike & $\mathrm{Y}$ & $\mathrm{N}$ \\
\hline AbCellera & AbC359 & 359 & undetermined & 64009.1.a & Humanized & $\operatorname{lgG1}$ & trimeric spike & $Y$ & $N$ \\
\hline AbCellera & AbC369 & 369 & S2 & 64012.1.a & Humanized & $\operatorname{lgG1}$ & trimeric spike & $\mathrm{Y}$ & $\mathrm{N}$ \\
\hline AbCellera & AbC397 & 397 & S2 & 64020.1.a & Humanized & $\operatorname{lgG1}$ & trimeric spike & $\mathrm{Y}$ & $Y$ \\
\hline AbCellera & $\mathrm{AbC} 415$ & 415 & S2 & 64026.1.a & Humanized & $\operatorname{lgG1}$ & trimeric spike & $Y$ & $N$ \\
\hline AbCellera & $\mathrm{AbC} 429$ & 429 & S2 & 64031.1.a & Humanized & $\operatorname{lgG1}$ & trimeric spike & $Y$ & $Y$ \\
\hline AbCellera & $\mathrm{AbC453}$ & 453 & S2 & 64036.1.a & Humanized & $\operatorname{lgG1}$ & trimeric spike & $Y$ & $N$ \\
\hline AbCellera & AbC459 & 459 & S2 & 64042.1.a & Humanized & $\operatorname{lgG1}$ & trimeric spike & $\mathrm{Y}$ & $\mathrm{N}$ \\
\hline AbCellera & $\mathrm{AbC} 463$ & 463 & S2 & 64045.1.a & Humanized & $\operatorname{IgG1}$ & trimeric spike & $Y$ & $N$ \\
\hline AbCellera & $\mathrm{AbC} 478$ & 478 & undetermined & 64051.1.a & Humanized & $\operatorname{lgG} 1$ & trimeric spike & $Y$ & $N$ \\
\hline AbCellera & $\mathrm{AbC} 489$ & 489 & S2 & 61061.1.a & Humanized & $\operatorname{lgG1}$ & trimeric spike & $\mathrm{Y}$ & $\mathrm{N}$ \\
\hline AbCellera & $\mathrm{AbC} 491$ & 491 & undetermined & 64064.1.a & Humanized & $\operatorname{lgG1}$ & trimeric spike & $\mathrm{Y}$ & $N$ \\
\hline AbCellera & $\mathrm{AbC} 500$ & 500 & S2 & 64067.1.a & Humanized & $\operatorname{lgG} 1$ & trimeric spike & $Y$ & $\mathrm{~N}$ \\
\hline AbCellera & AbC530 & 530 & undetermined & 64082.1.a & Humanized & $\operatorname{lgG1}$ & trimeric spike & $Y$ & $\mathrm{~N}$ \\
\hline AbCellera & $\mathrm{AbC} 554$ & 554 & S2 & 64087.1.a & Humanized & $\operatorname{lgG1}$ & trimeric spike & $Y$ & $\mathrm{~N}$ \\
\hline AbCellera & $\mathrm{AbC} 258$ & 258 & S2 & 63971.1.a & Humanized & $\operatorname{lgG1}$ & trimeric spike & $Y$ & $\mathrm{~N}$ \\
\hline AbCellera & AbC298 & 298 & S1 & 63989.1.a & Humanized & $\operatorname{lgG1}$ & trimeric spike & $\mathrm{Y}$ & $N$ \\
\hline
\end{tabular}




\begin{tabular}{|c|c|c|c|c|c|c|c|c|c|}
\hline AbCellera & AbC393 & 393 & RBD & 64017.1.a & Humanized & $\operatorname{lgG1}$ & trimeric spike & $Y$ & $\mathrm{~N}$ \\
\hline AbCellera & $\mathrm{AbC} 400$ & 400 & RBD & 64023.1.a & Humanized & $\operatorname{lgG1}$ & trimeric spike & $Y$ & $\mathrm{~N}$ \\
\hline AbCellera & $\mathrm{AbC} 447$ & 447 & RBD & 63900.1.a & Humanized & $\operatorname{lgG1}$ & trimeric spike & $\mathrm{Y}$ & $\mathrm{N}$ \\
\hline AbCellera & $\mathrm{AbC} 455$ & 455 & $\mathrm{~S} 2$ & 64039.1.a & Humanized & $\operatorname{lgG1}$ & trimeric spike & $Y$ & $\mathrm{~N}$ \\
\hline AbCellera & AbC469 & 469 & undetermined & 64048.1.a & Humanized & $\operatorname{lgG1}$ & trimeric spike & $\mathrm{Y}$ & $\mathrm{N}$ \\
\hline AbCellera & $\mathrm{AbC} 486$ & 486 & $\mathrm{~S} 2$ & 64058.1.a & Humanized & $\operatorname{lgG1}$ & trimeric spike & $Y$ & $\mathrm{~N}$ \\
\hline AbCellera & $\mathrm{AbC511}$ & 511 & $\mathrm{~S} 2$ & 64070.1.a & Humanized & $\operatorname{lgG1}$ & trimeric spike & $Y$ & $\mathrm{~N}$ \\
\hline AbCellera & $\mathrm{AbC} 513$ & 513 & $\mathrm{~S} 2$ & 64073.1.a & Humanized & $\operatorname{lgG1}$ & trimeric spike & $Y$ & $\mathrm{~N}$ \\
\hline AbCellera & $\mathrm{AbC} 518$ & 518 & $\mathrm{~S} 2$ & 64076.1.a & Humanized & $\operatorname{lgG1}$ & trimeric spike & $Y$ & $\mathrm{~N}$ \\
\hline AbCellera & $\mathrm{AbC} 525$ & 525 & $\mathrm{~S} 2$ & 64079.1.a & Humanized & $\operatorname{lgG1}$ & trimeric spike & $\mathrm{Y}$ & $Y$ \\
\hline AbCellera & $\mathrm{AbC557}$ & 557 & $\mathrm{~S} 2$ & 64090.1.a & Humanized & $\operatorname{lgG1}$ & trimeric spike & $Y$ & $\mathrm{~N}$ \\
\hline AbCellera & AbC558 & 558 & $\mathrm{~S} 2$ & 64093.1.a & Humanized & $\operatorname{lgG1}$ & trimeric spike & $Y$ & $\mathrm{~N}$ \\
\hline AbCellera & $\mathrm{AbC561}$ & 561 & $\mathrm{~S} 2$ & 64096.1.a & Humanized & $\operatorname{lgG1}$ & trimeric spike & $Y$ & $\mathrm{~N}$ \\
\hline AbCellera & $\mathrm{AbC} 574$ & 574 & undetermined & 64101.1.a & Humanized & $\operatorname{lgG1}$ & trimeric spike & $Y$ & $\mathrm{~N}$ \\
\hline AbCellera & $\mathrm{AbC585}$ & 585 & $\mathrm{~S} 2$ & 64104.1.a & Humanized & $\operatorname{lgG1}$ & trimeric spike & $\mathrm{Y}$ & $\mathrm{N}$ \\
\hline $\begin{array}{l}\text { Creative } \\
\text { Diagnostics }\end{array}$ & BIB112 & BIB112 & $\mathrm{S} 1$ & CABT-CS031 & Humanized & $\lg G$ & S1 & $\mathrm{N}$ & $Y$ \\
\hline $\begin{array}{l}\text { Creative } \\
\text { Diagnostics }\end{array}$ & BIB112 & BIB114 & S1 & CABT-CS033 & Humanized & $\lg G$ & S1 & $\mathrm{N}$ & $Y$ \\
\hline Sino Biological & D001 & D001 & undetermined & 40150-D001 & Mouse & $\operatorname{lgG1}$ & RBD & $\mathrm{N}$ & $Y$ \\
\hline Sino Biological & D002 & D002 & undetermined & 40150-D002 & Mouse & $\operatorname{lgG1}$ & RBD & $N$ & Y \\
\hline Sino Biological & D004 & D004 & undetermined & 40150-D004 & Mouse & $\operatorname{lgG1}$ & RBD & $\mathrm{N}$ & $Y$ \\
\hline Sino Biological & 007 & R007 & undetermined & 40150-R007 & Rabbit & $\lg G$ & trimeric spike & $\mathrm{N}$ & $Y$ \\
\hline Sino Biological & D003 & D003 & RBD & 40150-D003 & Mouse/ human & $\operatorname{lgG1}$ & RBD & $\mathrm{Y}$ & $\mathrm{N}$ \\
\hline Sino Biological & MM43 & 43 & RBD & 40591-MM43 & Mouse & $\lg G 1$ & S1 & $Y$ & $Y$ \\
\hline Sino Biological & MM57 & 57 & RBD & 40592-MM57 & Mouse & $\operatorname{lgG} 2 \mathrm{~b}$ & RBD & Y & Y \\
\hline Leinco & L2381 & 2381 & RBD & LT4000 & Human & $\operatorname{lgG1}$ & trimeric spike & $\mathrm{Y}$ & $Y$ \\
\hline Leinco & L2838 & 2838 & RBD & LT3000 & Human & $\operatorname{lgG1}$ & trimeric spike & $Y$ & $Y$ \\
\hline Leinco & L2355 & 2355 & RBD & LT5000 & Human & $\operatorname{lgG1}$ & trimeric spike & $Y$ & $Y$ \\
\hline Leinco & L2215 & 2215 & S1 NTD & LT6000 & Human & $\operatorname{lgG1}$ & trimeric spike & $\mathrm{Y}$ & $Y$ \\
\hline Leinco & L2136 & 2136 & undetermined & & Human & $\operatorname{lgG1}$ & trimeric spike & $\mathrm{N}$ & $Y$ \\
\hline
\end{tabular}




\begin{tabular}{|c|c|c|c|c|c|c|c|c|c|}
\hline Leinco & L2143 & 2143 & undetermined & & Human & $\lg G 1$ & trimeric spike & $\mathrm{N}$ & $\mathrm{Y}$ \\
\hline Leinco & L2146 & 2146 & S1 NTD & LT2000 & Human & $\lg G 1$ & trimeric spike & $\mathrm{N}$ & $Y$ \\
\hline Leinco & L2197 & 2197 & S1 NTD & & Human & $\operatorname{lgG} 1$ & trimeric spike & $\mathrm{N}$ & $Y$ \\
\hline
\end{tabular}


Table 2si | Anti-spike protein antibody pairs screened on LFA.

\begin{tabular}{|c|c|c|c|c|c|c|c|c|c|c|c|c|c|c|}
\hline \multirow[b]{2}{*}{ Index } & \multirow{2}{*}{$\begin{array}{l}\text { Capture } \\
\text { antibody }\end{array}$} & \multirow{2}{*}{$\begin{array}{l}\text { Detector } \\
\text { antibody }\end{array}$} & \multicolumn{2}{|c|}{ Average rank } & \multirow[b]{2}{*}{ Index } & \multirow{2}{*}{$\begin{array}{l}\text { Capture } \\
\text { antibody }\end{array}$} & \multirow{2}{*}{$\begin{array}{l}\text { Detector } \\
\text { antibody }\end{array}$} & \multicolumn{2}{|c|}{ Average rank } & \multirow[b]{2}{*}{ Index } & \multirow{2}{*}{$\begin{array}{l}\text { Capture } \\
\text { antibody }\end{array}$} & \multirow{2}{*}{$\begin{array}{l}\text { Detector } \\
\text { antibody }\end{array}$} & \multicolumn{2}{|c|}{ Average rank } \\
\hline & & & round 1 & round 2 & & & & round 1 & round 2 & & & & round 1 & round 2 \\
\hline 1 & $\begin{array}{c}\text { AbCellera clone } \\
131\end{array}$ & $\begin{array}{c}\text { AbCellera clone } \\
131\end{array}$ & 39 & - & 17 & $\begin{array}{c}\text { AbCellera clone } \\
277\end{array}$ & $\begin{array}{l}\text { AbCellera clone } \\
4229\end{array}$ & - & 222 & 35 & $\begin{array}{l}\text { AbCellera clone } \\
283\end{array}$ & $\begin{array}{l}\text { AbCellera clone } \\
308\end{array}$ & - & 309.5 \\
\hline & & Creative & & & & AbCellera clone & AbCellera clone & & & & AbCellera clone & AbCellera clone & & \\
\hline & & Diagnostics & & & 18 & 277 & 447 & - & 139 & 36 & 283 & 310 & - & 463 \\
\hline 2 & $\begin{array}{c}\text { AbCellera clone } \\
131\end{array}$ & $\begin{array}{c}\text { CABT- } \\
\text { CS031[BIB112] }\end{array}$ & 45 & - & 19 & $\begin{array}{c}\text { AbCellera clone } \\
277\end{array}$ & $\begin{array}{c}\text { AbCellera clone } \\
459\end{array}$ & - & 392 & 37 & $\begin{array}{c}\text { AbCellera clone } \\
283\end{array}$ & $\begin{array}{l}\text { AbCellera clone } \\
\quad 313\end{array}$ & - & 321.5 \\
\hline & & Creative & & & & AbCellera clone & AbCellera clone & & & & AbCellera clone & AbCellera clone & & \\
\hline & & Diagnostics & & & 20 & 277 & 525 & - & 523 & 38 & 283 & 353 & - & 458 \\
\hline 3 & $\begin{array}{c}\text { AbCellera clone } \\
131\end{array}$ & $\begin{array}{c}\text { CABT- } \\
\text { CS033[BIB114] }\end{array}$ & 54.5 & - & 21 & $\begin{array}{c}\text { AbCellera clone } \\
277\end{array}$ & $\begin{array}{c}\text { Leinco clone } \\
2136\end{array}$ & - & 526 & 39 & $\begin{array}{c}\text { AbCellera clone } \\
283\end{array}$ & $\begin{array}{c}\text { AbCellera clone } \\
397\end{array}$ & - & 48.5 \\
\hline 4 & $\begin{array}{c}\text { AbCellera clone } \\
131\end{array}$ & $\begin{array}{c}\text { Sino Biological } \\
\text { 40150-D001 }\end{array}$ & 25 & - & 22 & $\begin{array}{c}\text { AbCellera clone } \\
277\end{array}$ & $\begin{array}{l}\text { Leinco clone } \\
2143\end{array}$ & - & 149 & 40 & $\begin{array}{c}\text { AbCellera clone } \\
283\end{array}$ & $\begin{array}{l}\text { AbCellera clone } \\
429\end{array}$ & - & 302.5 \\
\hline 5 & $\begin{array}{c}\text { AbCellera clone } \\
131\end{array}$ & $\begin{array}{c}\text { Sino Biological } \\
\text { 40150-D002 }\end{array}$ & 36.5 & - & 23 & $\begin{array}{c}\text { AbCellera clone } \\
277\end{array}$ & $\begin{array}{l}\text { Leinco clone } \\
2146\end{array}$ & - & 44 & 41 & $\begin{array}{c}\text { AbCellera clone } \\
283\end{array}$ & $\begin{array}{c}\text { AbCellera clone } \\
447\end{array}$ & - & 300 \\
\hline 6 & $\begin{array}{c}\text { AbCellera clone } \\
131\end{array}$ & $\begin{array}{c}\text { Sino Biological } \\
\text { 40150-D003 }\end{array}$ & 50 & - & 24 & $\begin{array}{c}\text { AbCellera clone } \\
277\end{array}$ & $\begin{array}{c}\text { Leinco clone } \\
2197\end{array}$ & - & 308.5 & 42 & $\begin{array}{c}\text { AbCellera clone } \\
283\end{array}$ & $\begin{array}{c}\text { AbCellera clone } \\
459\end{array}$ & - & 349.5 \\
\hline 7 & $\begin{array}{c}\text { AbCellera clone } \\
131\end{array}$ & $\begin{array}{c}\text { Sino Biological } \\
\text { 40150-D004 }\end{array}$ & 46 & - & 25 & $\begin{array}{c}\text { AbCellera clone } \\
277\end{array}$ & $\begin{array}{c}\text { Leinco clone } \\
2215\end{array}$ & - & 127.5 & 43 & $\begin{array}{c}\text { AbCellera clone } \\
283\end{array}$ & $\begin{array}{l}\text { AbCellera clone } \\
\quad 525\end{array}$ & - & 548 \\
\hline 8 & $\begin{array}{c}\text { AbCellera clone } \\
131\end{array}$ & $\begin{array}{c}\text { Sino Biological } \\
\text { 40150-R007 }\end{array}$ & 35.5 & - & 26 & $\begin{array}{l}\text { AbCellera clone } \\
277\end{array}$ & $\begin{array}{l}\text { Leinco clone } \\
2355\end{array}$ & - & 13 & 44 & $\begin{array}{c}\text { AbCellera clone } \\
283\end{array}$ & $\begin{array}{c}\text { Leinco clone } \\
2136\end{array}$ & - & 292.5 \\
\hline 9 & $\begin{array}{c}\text { AbCellera clone } \\
277\end{array}$ & $\begin{array}{c}\text { AbCellera clone } \\
277\end{array}$ & - & 551 & 27 & $\begin{array}{c}\text { AbCellera clone } \\
277\end{array}$ & $\begin{array}{c}\text { Leinco clone } \\
2381\end{array}$ & - & 57 & 45 & $\begin{array}{c}\text { AbCellera clone } \\
283\end{array}$ & $\begin{array}{c}\text { Leinco clone } \\
2143\end{array}$ & - & 247 \\
\hline 10 & $\begin{array}{c}\text { AbCellera clone } \\
277\end{array}$ & $\begin{array}{l}\text { AbCellera clone } \\
283\end{array}$ & 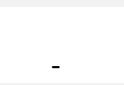 & & 20 & $\begin{array}{l}\text { AbCellera clone } \\
277\end{array}$ & $\begin{array}{l}\text { Leinco clone } \\
2838\end{array}$ & - & 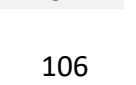 & 46 & $\begin{array}{c}\text { AbCellera clone } \\
283\end{array}$ & $\begin{array}{c}\text { Leinco clone } \\
2146\end{array}$ & - & 326.5 \\
\hline 11 & $\begin{array}{c}\text { AbCellera clone } \\
277\end{array}$ & $\begin{array}{l}\text { AbCellera clone } \\
291\end{array}$ & - & 473 & 29 & $\begin{array}{c}\text { AbCellera clone } \\
277\end{array}$ & $\begin{array}{c}\text { Sino Biological } \\
\text { 40150-D001 }\end{array}$ & - & 25 & 47 & $\begin{array}{c}\text { AbCellera clone } \\
283\end{array}$ & $\begin{array}{c}\text { Leinco clone } \\
2197\end{array}$ & - & 382.5 \\
\hline 12 & $\begin{array}{c}\text { AbCellera clone } \\
277\end{array}$ & $\begin{array}{c}\text { AbCellera clone } \\
308\end{array}$ & - & 113 & 30 & $\begin{array}{c}\text { AbCellera clone } \\
277\end{array}$ & $\begin{array}{c}\text { Sino Biological } \\
\text { 40150-D002 }\end{array}$ & - & 17.5 & 48 & $\begin{array}{c}\text { AbCellera clone } \\
283\end{array}$ & $\begin{array}{c}\text { Leinco clone } \\
2215\end{array}$ & - & 289 \\
\hline 13 & $\begin{array}{c}\text { AbCellera clone } \\
277\end{array}$ & $\begin{array}{l}\text { AbCellera clone } \\
310\end{array}$ & - & 440.5 & 31 & $\begin{array}{c}\text { AbCellera clone } \\
277\end{array}$ & $\begin{array}{c}\text { Sino Biological } \\
\text { 40150-D004 }\end{array}$ & - & 113.5 & 49 & $\begin{array}{c}\text { AbCellera clone } \\
283\end{array}$ & $\begin{array}{c}\text { Leinco clone } \\
2355\end{array}$ & - & 76 \\
\hline 14 & $\begin{array}{c}\text { AbCellera clone } \\
277\end{array}$ & $\begin{array}{l}\text { AbCellera clone } \\
\quad 313\end{array}$ & - & 368 & 32 & $\begin{array}{c}\text { AbCellera clone } \\
283\end{array}$ & $\begin{array}{c}\text { AbCellera clone } \\
277\end{array}$ & - & 433 & 50 & $\begin{array}{c}\text { AbCellera clone } \\
283\end{array}$ & $\begin{array}{c}\text { Leinco clone } \\
2381\end{array}$ & - & 148.5 \\
\hline 15 & $\begin{array}{c}\text { AbCellera clone } \\
277\end{array}$ & $\begin{array}{c}\text { AbCellera clone } \\
353\end{array}$ & - & 563 & 33 & $\begin{array}{c}\text { AbCellera clone } \\
283\end{array}$ & $\begin{array}{c}\text { AbCellera clone } \\
283\end{array}$ & - & 551.5 & 51 & $\begin{array}{c}\text { AbCellera clone } \\
283\end{array}$ & $\begin{array}{c}\text { Leinco clone } \\
2838\end{array}$ & - & 120.5 \\
\hline 16 & $\begin{array}{c}\text { AbCellera clone } \\
277\end{array}$ & $\begin{array}{l}\text { AbCellera clone } \\
397\end{array}$ & - & 549 & 34 & $\begin{array}{c}\text { AbCellera clone } \\
283\end{array}$ & $\begin{array}{l}\text { AbCellera clone } \\
\qquad 291\end{array}$ & - & 390 & 52 & $\begin{array}{c}\text { AbCellera clone } \\
283\end{array}$ & $\begin{array}{c}\text { Sino Biological } \\
\text { 40150-D001 }\end{array}$ & - & 114.5 \\
\hline
\end{tabular}




\begin{tabular}{|c|c|c|c|c|c|c|c|c|c|c|c|c|c|c|}
\hline \multirow[b]{2}{*}{ Index } & \multirow{2}{*}{$\begin{array}{l}\text { Capture } \\
\text { antibody }\end{array}$} & \multirow{2}{*}{$\begin{array}{l}\text { Detector } \\
\text { antibody }\end{array}$} & \multicolumn{2}{|c|}{ Average rank } & \multirow[b]{2}{*}{ Index } & \multirow{2}{*}{$\begin{array}{l}\text { Capture } \\
\text { antibody }\end{array}$} & \multirow{2}{*}{$\begin{array}{l}\text { Detector } \\
\text { antibody }\end{array}$} & \multicolumn{2}{|c|}{ Average rank } & \multirow[b]{2}{*}{ Index } & \multirow{2}{*}{$\begin{array}{l}\text { Capture } \\
\text { antibody }\end{array}$} & \multirow{2}{*}{$\begin{array}{l}\text { Detector } \\
\text { antibody }\end{array}$} & \multicolumn{2}{|c|}{ Average rank } \\
\hline & & & round 1 & round 2 & & & & round 1 & round 2 & & & & round 1 & round 2 \\
\hline 53 & $\begin{array}{c}\text { AbCellera clone } \\
283\end{array}$ & $\begin{array}{l}\text { Sino Biological } \\
\text { 40150-D002 }\end{array}$ & - & 156 & 72 & $\begin{array}{l}\text { AbCellera clone } \\
291\end{array}$ & $\begin{array}{l}\text { Leinco clone } \\
2355\end{array}$ & - & 16 & 91 & $\begin{array}{c}\text { AbCellera clone } \\
308\end{array}$ & $\begin{array}{c}\text { Leinco clone } \\
2143\end{array}$ & - & 183 \\
\hline 54 & $\begin{array}{l}\text { AbCellera clone } \\
283\end{array}$ & $\begin{array}{c}\text { Sino Biological } \\
40150-D 004\end{array}$ & - & 223 & 73 & $\begin{array}{c}\text { AbCellera clone } \\
291\end{array}$ & $\begin{array}{c}\text { Leinco clone } \\
2381\end{array}$ & - & 39.5 & 92 & $\begin{array}{l}\text { AbCellera clone } \\
308\end{array}$ & $\begin{array}{l}\text { Leinco clone } \\
2146\end{array}$ & 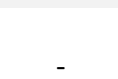 & 387 \\
\hline 55 & $\begin{array}{l}\text { AbCellera clone } \\
291\end{array}$ & $\begin{array}{l}\text { AbCellera clone } \\
277\end{array}$ & - & 381 & 74 & $\begin{array}{l}\text { AbCellera clone } \\
291\end{array}$ & $\begin{array}{l}\text { Leinco clone } \\
2838\end{array}$ & - & 40 & 93 & $\begin{array}{l}\text { AbCellera clone } \\
308\end{array}$ & $\begin{array}{c}\text { Leinco clone } \\
2197\end{array}$ & - & 226 \\
\hline 56 & $\begin{array}{c}\text { AbCellera clone } \\
291\end{array}$ & $\begin{array}{c}\text { AbCellera clone } \\
283\end{array}$ & - & 451.5 & 75 & $\begin{array}{l}\text { AbCellera clone } \\
291\end{array}$ & $\begin{array}{c}\text { Sino Biological } \\
40150-D 001\end{array}$ & - & 64.5 & 94 & $\begin{array}{c}\text { AbCellera clone } \\
308\end{array}$ & $\begin{array}{l}\text { Leinco clone } \\
2215\end{array}$ & - & 230.5 \\
\hline 57 & $\begin{array}{c}\text { AbCellera clone } \\
291\end{array}$ & $\begin{array}{c}\text { AbCellera clone } \\
291\end{array}$ & - & 482.5 & 76 & $\begin{array}{l}\text { AbCellera clone } \\
291\end{array}$ & $\begin{array}{c}\text { Sino Biological } \\
40150-D 002\end{array}$ & - & 43.5 & 95 & $\begin{array}{c}\text { AbCellera clone } \\
308\end{array}$ & $\begin{array}{l}\text { Leinco clone } \\
2355\end{array}$ & - & 99.5 \\
\hline 58 & $\begin{array}{c}\text { AbCellera clone } \\
291\end{array}$ & $\begin{array}{l}\text { AbCellera clone } \\
308\end{array}$ & - & 244.5 & 77 & $\begin{array}{l}\text { AbCellera clone } \\
291\end{array}$ & $\begin{array}{c}\text { Sino Biological } \\
40150-D 004\end{array}$ & - & 65.5 & 96 & $\begin{array}{c}\text { AbCellera clone } \\
308\end{array}$ & $\begin{array}{c}\text { Leinco clone } \\
2381\end{array}$ & - & 153 \\
\hline 59 & $\begin{array}{c}\text { AbCellera clone } \\
291\end{array}$ & $\begin{array}{l}\text { AbCellera clone } \\
310\end{array}$ & - & 332 & 78 & $\begin{array}{c}\text { AbCellera clone } \\
308\end{array}$ & $\begin{array}{c}\text { AbCellera clone } \\
277\end{array}$ & - & 510 & 97 & $\begin{array}{c}\text { AbCellera clone } \\
308\end{array}$ & $\begin{array}{c}\text { Leinco clone } \\
2838\end{array}$ & - & 78.5 \\
\hline 60 & $\begin{array}{c}\text { AbCellera clone } \\
291\end{array}$ & $\begin{array}{l}\text { AbCellera clone } \\
\quad 313\end{array}$ & - & 523 & 79 & $\begin{array}{c}\text { AbCellera clone } \\
308\end{array}$ & $\begin{array}{l}\text { AbCellera clone } \\
283\end{array}$ & - & 497.5 & 98 & $\begin{array}{c}\text { AbCellera clone } \\
308\end{array}$ & $\begin{array}{c}\text { Sino Biological } \\
40150-D 001\end{array}$ & - & 206.5 \\
\hline 61 & $\begin{array}{c}\text { AbCellera clone } \\
291\end{array}$ & $\begin{array}{c}\text { AbCellera clone } \\
353\end{array}$ & - & 498 & 80 & $\begin{array}{c}\text { AbCellera clone } \\
308\end{array}$ & $\begin{array}{l}\text { AbCellera clone } \\
291\end{array}$ & - & 386 & 99 & $\begin{array}{c}\text { AbCellera clone } \\
308\end{array}$ & $\begin{array}{c}\text { Sino Biological } \\
40150-D 002\end{array}$ & - & 157 \\
\hline 62 & $\begin{array}{l}\text { AbCellera clone } \\
291\end{array}$ & $\begin{array}{c}\text { AbCellera clone } \\
397\end{array}$ & - & 525.5 & 81 & $\begin{array}{l}\text { AbCellera clone } \\
308\end{array}$ & $\begin{array}{l}\text { AbCellera clone } \\
\quad 308\end{array}$ & - & 400. & 100 & $\begin{array}{c}\text { AbCellera clone } \\
308\end{array}$ & $\begin{array}{c}\text { Sino Biological } \\
40150-D 004\end{array}$ & - & 29.5 \\
\hline 63 & $\begin{array}{c}\text { AbCellera clone } \\
291\end{array}$ & $\begin{array}{c}\text { AbCellera clone } \\
429\end{array}$ & - & 214 & 82 & $\begin{array}{c}\text { AbCellera clone } \\
308\end{array}$ & $\begin{array}{l}\text { AbCellera clone } \\
\quad 310\end{array}$ & - & 518 & 101 & $\begin{array}{c}\text { AbCellera clone } \\
310\end{array}$ & $\begin{array}{c}\text { AbCellera clone } \\
277\end{array}$ & - & 430 \\
\hline 64 & $\begin{array}{c}\text { AbCellera clone } \\
291\end{array}$ & $\begin{array}{c}\text { AbCellera clone } \\
447\end{array}$ & - & 101.5 & 83 & $\begin{array}{c}\text { AbCellera clone } \\
308\end{array}$ & $\begin{array}{l}\text { AbCellera clone } \\
313\end{array}$ & - & 219. & 102 & $\begin{array}{c}\text { Cellera cl } \\
310\end{array}$ & $\begin{array}{c}\text { AbCellera clone } \\
283\end{array}$ & - & 534 \\
\hline 65 & $\begin{array}{c}\text { AbCellera clone } \\
291\end{array}$ & $\begin{array}{c}\text { AbCellera clone } \\
459\end{array}$ & - & 443 & 84 & $\begin{array}{c}\text { AbCellera clone } \\
308\end{array}$ & $\begin{array}{c}\text { AbCellera clone } \\
\quad 353\end{array}$ & - & 20. & 103 & $\begin{array}{c}\text { AbCellera clone } \\
310\end{array}$ & $\begin{array}{c}\text { AbCellera clone } \\
291\end{array}$ & - & 302 \\
\hline 66 & $\begin{array}{c}\text { AbCellera clone } \\
291\end{array}$ & $\begin{array}{c}\text { AbCellera clone } \\
\quad 525\end{array}$ & - & 433 & 85 & $\begin{array}{c}\text { AbCellera clone } \\
308\end{array}$ & $\begin{array}{c}\text { AbCellera clone } \\
397\end{array}$ & - & 550 & 104 & $\begin{array}{l}\text { AbCellera clone } \\
310\end{array}$ & $\begin{array}{l}\text { AbCellera clone } \\
308\end{array}$ & - & 336 \\
\hline 67 & $\begin{array}{c}\text { AbCellera clone } \\
291\end{array}$ & $\begin{array}{c}\text { Leinco clone } \\
2136\end{array}$ & - & 273.5 & 86 & $\begin{array}{c}\text { AbCellera clone } \\
308\end{array}$ & $\begin{array}{l}\text { AbCellera clone } \\
4229\end{array}$ & - & נ.ענד & 105 & $\begin{array}{c}\text { AbCellera clone } \\
310\end{array}$ & $\begin{array}{l}\text { AbCellera clone } \\
310\end{array}$ & - & 546.5 \\
\hline 68 & $\begin{array}{c}\text { AbCellera clone } \\
291\end{array}$ & $\begin{array}{c}\text { Leinco clone } \\
2143\end{array}$ & - & 210.5 & 87 & $\begin{array}{c}\text { AbCellera clone } \\
308\end{array}$ & $\begin{array}{c}\text { AbCellera clone } \\
447\end{array}$ & - & 262.5 & 106 & $\begin{array}{c}\text { AbCellera clone } \\
310\end{array}$ & $\begin{array}{c}\text { AbCellera clone } \\
313\end{array}$ & - & 317.5 \\
\hline 69 & $\begin{array}{l}\text { AbCellera clone } \\
291\end{array}$ & $\begin{array}{c}\text { Leinco clone } \\
2146\end{array}$ & - & 247 & 88 & $\begin{array}{l}\text { AbCellera clone } \\
308\end{array}$ & $\begin{array}{l}\text { AbCellera clone } \\
459\end{array}$ & - & 199 & 107 & $\begin{array}{l}\text { AbCellera clone } \\
310\end{array}$ & $\begin{array}{c}\text { AbCellera clone } \\
353\end{array}$ & - & 338 \\
\hline 70 & $\begin{array}{l}\text { AbCellera clone } \\
291\end{array}$ & $\begin{array}{c}\text { Leinco clone } \\
2197\end{array}$ & - & 224 & 89 & $\begin{array}{l}\text { AbCellera clone } \\
308\end{array}$ & $\begin{array}{l}\text { AbCellera clone } \\
525\end{array}$ & - & 354.5 & 108 & $\begin{array}{l}\text { AbCellera clone } \\
310\end{array}$ & $\begin{array}{c}\text { AbCellera clone } \\
397\end{array}$ & - & 464.5 \\
\hline 71 & $\begin{array}{c}\text { AbCellera clone } \\
291\end{array}$ & $\begin{array}{c}\text { Leinco clone } \\
2215\end{array}$ & - & 134.5 & 90 & $\begin{array}{c}\text { AbCellera clone } \\
308\end{array}$ & $\begin{array}{l}\text { Leinco clone } \\
2136\end{array}$ & - & 360.5 & 109 & $\begin{array}{c}\text { AbCellera clone } \\
310\end{array}$ & $\begin{array}{l}\text { AbCellera clone } \\
4429\end{array}$ & - & 267 \\
\hline
\end{tabular}




\begin{tabular}{|c|c|c|c|c|c|c|c|c|c|c|c|c|c|c|}
\hline \multirow[b]{2}{*}{ Index } & \multirow{2}{*}{$\begin{array}{l}\text { Capture } \\
\text { antibody }\end{array}$} & \multirow{2}{*}{$\begin{array}{l}\text { Detector } \\
\text { antibody }\end{array}$} & \multicolumn{2}{|c|}{ Average rank } & \multirow[b]{2}{*}{ Index } & \multirow{2}{*}{$\begin{array}{l}\text { Capture } \\
\text { antibody }\end{array}$} & \multirow{2}{*}{$\begin{array}{l}\text { Detector } \\
\text { antibody }\end{array}$} & \multicolumn{2}{|c|}{ Average rank } & \multirow[b]{2}{*}{ Index } & \multirow{2}{*}{$\begin{array}{l}\text { Capture } \\
\text { antibody }\end{array}$} & \multirow{2}{*}{$\begin{array}{l}\text { Detector } \\
\text { antibody }\end{array}$} & \multicolumn{2}{|c|}{ Average rank } \\
\hline & & & round 1 & round 2 & & & & round 1 & round 2 & & & & round 1 & round 2 \\
\hline & AbCellera clone & AbCellera clone & & & & AbCellera clone & AbCellera clone & & & & AbCellera clone & AbCellera clone & & \\
\hline \multirow[t]{2}{*}{110} & 310 & 447 & - & 246 & 129 & 313 & 313 & - & 452.5 & 148 & 353 & 283 & - & 415.5 \\
\hline & AbCellera clone & AbCellera clone & & & & AbCellera clone & AbCellera clone & & & & AbCellera clone & AbCellera clone & & \\
\hline \multirow[t]{2}{*}{111} & 310 & 459 & - & 256.5 & 130 & 313 & 353 & - & 536 & 149 & 353 & 291 & - & 485 \\
\hline & AbCellera clone & AbCellera clone & & & & AbCellera clone & AbCellera clone & & & & AbCellera clone & AbCellera clone & & \\
\hline \multirow[t]{2}{*}{112} & 310 & 525 & - & 408.5 & 131 & 313 & 397 & - & 503.5 & 150 & 353 & 308 & - & 268 \\
\hline & AbCellera clone & Leinco clone & & & & AbCellera clone & AbCellera clone & & & & AbCellera clone & AbCellera clone & & \\
\hline \multirow[t]{2}{*}{113} & 310 & 2136 & - & 357.5 & 132 & 313 & 429 & - & 303 & 151 & 353 & 310 & - & 421 \\
\hline & AbCellera clone & Leinco clone & & & & AbCellera clone & AbCellera clone & & & & AbCellera clone & AbCellera clone & & \\
\hline \multirow[t]{2}{*}{114} & 310 & 2143 & - & 290 & 133 & 313 & 447 & - & 227.5 & 152 & 353 & 313 & - & 451.5 \\
\hline & AbCellera clone & Leinco clone & & & & AbCellera clone & AbCellera clone & & & & AbCellera clone & AbCellera clone & & \\
\hline \multirow[t]{2}{*}{115} & 310 & 2146 & - & 270.5 & 134 & 313 & 459 & - & 533.5 & 153 & 353 & 353 & - & 507 \\
\hline & AbCellera clone & Leinco clone & & & & AbCellera clone & AbCellera clone & & & & AbCellera clone & AbCellera clone & & \\
\hline \multirow[t]{2}{*}{116} & 310 & 2197 & - & 336 & 135 & 313 & 525 & - & 391.5 & 154 & 353 & 397 & - & 464 \\
\hline & AbCellera clone & Leinco clone & & & & AbCellera clone & Leinco clone & & & & AbCellera clone & AbCellera clone & & \\
\hline \multirow[t]{2}{*}{117} & 310 & 2215 & - & 185.5 & 136 & 313 & 2136 & - & 276 & 155 & 353 & 429 & - & 429.5 \\
\hline & AbCellera clone & Leinco clone & & & & AbCellera clone & Leinco clone & & & & AbCellera clone & AbCellera clone & & \\
\hline \multirow[t]{2}{*}{118} & 310 & 2355 & - & 99 & 137 & 313 & 2143 & - & 239.5 & 156 & 353 & 447 & - & 143 \\
\hline & AbCellera clone & Leinco clone & & & & AbCellera clone & Leinco clone & & & & AbCellera clone & AbCellera clone & & \\
\hline \multirow[t]{2}{*}{119} & 310 & 2381 & - & 133 & 138 & 313 & 2146 & - & 348 & 157 & 353 & 459 & - & 551.5 \\
\hline & AbCellera clone & Leinco clone & & & & AbCellera clone & Leinco clone & & & & AbCeller & AbCeller & & \\
\hline 120 & 310 & 2838 & - & 45.5 & 139 & 313 & 2197 & - & 344 & 158 & 353 & 525 & - & 520.5 \\
\hline & AbCellera clone & Sino Biological & & & & AbCellera clone & Leinco clone & & & & AbCellera clone & Leinco clone & & \\
\hline 121 & 310 & 40150-D001 & - & 121.5 & 140 & 313 & 2215 & - & 152 & 159 & 353 & 2136 & - & 223 \\
\hline & AbCellera clone & Sino Biological & & & & AbCellera clone & Leinco clone & & & & AbCellera clone & Leinco clone & & \\
\hline 122 & 310 & 40150-D002 & - & 379.5 & 141 & 313 & 2355 & - & 47.5 & 160 & 353 & 2143 & - & 247 \\
\hline & AbCellera clone & Sino Biological & & & & AbCellera clone & Leinco clone & & & & AbCellera clone & Leinco clone & & \\
\hline 123 & 310 & 40150-D004 & - & 231.5 & 142 & 313 & 2381 & - & $7 \varepsilon$ & 161 & 353 & 2146 & - & 397.5 \\
\hline & AbCellera clone & AbCellera clone & & & & AbCellera clone & Leinco clone & & & & AbCellera clone & Leinco clone & & \\
\hline 124 & 313 & 277 & - & 470 & 143 & 313 & 2838 & - & 25 & 162 & 353 & 2197 & - & 329 \\
\hline 125 & $\begin{array}{c}\text { AbCellera clone } \\
313\end{array}$ & $\begin{array}{l}\text { AbCellera clone } \\
283\end{array}$ & - & 446 & 144 & $\begin{array}{c}\text { AbCellera clone } \\
313\end{array}$ & $\begin{array}{c}\text { Sino Biological } \\
40150-D 001\end{array}$ & - & 63 & 163 & $\begin{array}{c}\text { AbCellera clone } \\
353\end{array}$ & $\begin{array}{l}\text { Leinco clone } \\
2215\end{array}$ & - & 226 \\
\hline & AbCellera clone & AbCellera clone & & & & AbCellera clone & Sino Biological & & & & AbCellera clone & Leinco clone & & \\
\hline 126 & 313 & 291 & - & 473 & 145 & 313 & 40150-D002 & - & 68.5 & 164 & 353 & 2355 & - & 66.5 \\
\hline & AbCellera clone & AbCellera clone & & & & AbCellera clone & Sino Biological & & & & AbCellera clone & Leinco clone & & \\
\hline 127 & 313 & 308 & - & 293 & 146 & 313 & 40150-D004 & - & 165 & 165 & 353 & 2381 & - & 92.5 \\
\hline & AbCellera clone & AbCellera clone & & & & AbCellera clone & AbCellera clone & & & & AbCellera clone & Leinco clone & & \\
\hline 128 & 313 & 310 & - & 339.5 & 147 & 353 & 277 & - & 559 & 166 & 353 & 2838 & - & 133 \\
\hline
\end{tabular}




\begin{tabular}{|c|c|c|c|c|c|c|c|c|c|c|c|c|c|c|}
\hline \multirow[b]{2}{*}{ Index } & \multirow{2}{*}{$\begin{array}{l}\text { Capture } \\
\text { antibody }\end{array}$} & \multirow{2}{*}{$\begin{array}{l}\text { Detector } \\
\text { antibody }\end{array}$} & \multicolumn{2}{|c|}{ Average rank } & \multirow[b]{2}{*}{ Index } & \multirow{2}{*}{$\begin{array}{l}\text { Capture } \\
\text { antibody }\end{array}$} & \multirow{2}{*}{$\begin{array}{l}\text { Detector } \\
\text { antibody }\end{array}$} & \multicolumn{2}{|c|}{ Average rank } & \multirow[b]{2}{*}{ Index } & \multirow{2}{*}{$\begin{array}{l}\text { Capture } \\
\text { antibody }\end{array}$} & \multirow{2}{*}{$\begin{array}{l}\text { Detector } \\
\text { antibody }\end{array}$} & \multicolumn{2}{|c|}{ Average rank } \\
\hline & & & round 1 & round 2 & & & & round 1 & round 2 & & & & round 1 & round 2 \\
\hline & AbCellera clone & Sino Biological & & & & AbCellera clone & Leinco clone & & & & AbCellera clone & Leinco clone & & \\
\hline \multirow[t]{2}{*}{167} & 353 & 40150-D001 & - & 50.5 & 186 & 397 & 2215 & - & 486 & 205 & 429 & 2136 & - & 281 \\
\hline & AbCellera clone & Sino Biological & & & & AbCellera clone & Leinco clone & & & & AbCellera clone & Leinco clone & & \\
\hline \multirow[t]{2}{*}{168} & 353 & 40150-D002 & - & 88.5 & 187 & 397 & 2355 & - & 270.5 & 206 & 429 & 2143 & - & 163.5 \\
\hline & AbCellera clone & Sino Biological & & & & AbCellera clone & Leinco clone & & & & AbCellera clone & Leinco clone & & \\
\hline \multirow[t]{2}{*}{169} & 353 & 40150-D004 & - & 170.5 & 188 & 397 & 2381 & - & 350.5 & 207 & 429 & 2146 & - & 303 \\
\hline & AbCellera clone & AbCellera clone & & & & AbCellera clone & Leinco clone & & & & AbCellera clone & Leinco clone & & \\
\hline 170 & 397 & 277 & - & 458.5 & 189 & 397 & 2838 & - & 297.5 & 208 & 429 & 2197 & - & 252.5 \\
\hline \multirow[t]{2}{*}{171} & $\begin{array}{c}\text { AbCellera clone } \\
397\end{array}$ & $\begin{array}{c}\text { AbCellera clone } \\
283\end{array}$ & - & 513 & 190 & $\begin{array}{c}\text { AbCellera clone } \\
397\end{array}$ & $\begin{array}{c}\text { Sino Biological } \\
40150-D 001\end{array}$ & - & 288.5 & 209 & $\begin{array}{c}\text { AbCellera clone } \\
429\end{array}$ & $\begin{array}{c}\text { Leinco clone } \\
2215\end{array}$ & - & 215.5 \\
\hline & AbCellera clone & AbCellera clone & & & & AbCellera clone & Sino Biological & & & & AbCellera clone & Leinco clone & & \\
\hline 172 & 397 & 291 & - & 342.5 & 191 & 397 & 40150 & - & 530.5 & 210 & 429 & 5 & - & 48.5 \\
\hline \multirow[t]{2}{*}{173} & $\begin{array}{c}\text { AbCellera clone } \\
397\end{array}$ & $\begin{array}{c}\text { AbCellera clone } \\
308\end{array}$ & - & 432 & 192 & $\begin{array}{c}\text { AbCellera clone } \\
397\end{array}$ & $\begin{array}{c}\text { Sino Biological } \\
\text { 40150-D004 }\end{array}$ & - & 455 & 211 & $\begin{array}{c}\text { AbCellera clone } \\
429\end{array}$ & $\begin{array}{c}\text { Leinco clone } \\
2381\end{array}$ & - & 87 \\
\hline & AbCellera clone & AbCellera clone & & & & $\begin{array}{c}\text { AbCellera clone } \\
429\end{array}$ & $\begin{array}{c}\text { AbCellera clone } \\
277\end{array}$ & & & & AbCellera clone & $\begin{array}{c}\text { Leinco clone } \\
2838\end{array}$ & & \\
\hline 174 & AbCellera clone & AbCellera clone & 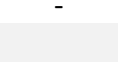 & & 193 & $\begin{array}{c}429 \\
\text { AbCellera clone }\end{array}$ & AbCellera clone & 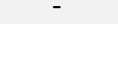 & & 212 & AbCellera clone & Sino Biological & - & 5 \\
\hline \multirow[t]{2}{*}{175} & 397 & 313 & - & 390.5 & 194 & 429 & 283 & - & 493 & 213 & 429 & 40150-D001 & - & 43 \\
\hline & AbCellera clone & AbCellera clone & & & & AbCellera clone & AbCellera clone & & & & AbCellera clone & Sino Biological & & \\
\hline \multirow[t]{2}{*}{176} & 397 & 353 & - & 400.5 & 195 & 429 & 291 & - & 174 & 214 & 429 & 40150-D002 & - & 63 \\
\hline & AbCellera clone & AbCellera clone & & & & AbCellera clone & AbCellera clone & & & & AbCellera clone & Sino Biological & & \\
\hline \multirow[t]{2}{*}{177} & 397 & 397 & - & 502.5 & 196 & 429 & 308 & - & 41 & 215 & 429 & 40150-D004 & - & 149.5 \\
\hline & AbCellera clone & AbCellera clone & & & & AbCellera clone & AbCellera clone & & & & AbCellera clone & AbCellera clone & & \\
\hline 178 & 397 & 429 & - & 439.5 & 197 & 429 & 310 & - & 444 & 216 & 447 & 277 & - & 331.5 \\
\hline & AbCellera clone & AbCellera clone & & & & AbCellera clone & AbCellera clone & & & & AbCellera clone & AbCellera clone & & \\
\hline 179 & 397 & 447 & - & 3 & 198 & 429 & 313 & - & 1 & 217 & 447 & 283 & - & 334.5 \\
\hline & AbCellera clone & AbCellera clone & & & & AbCellera clone & AbCellera clone & & & & AbCellera c & AbCellera clone & & \\
\hline 180 & 397 & 459 & - & 249.5 & 199 & 429 & 353 & - & 335 & 218 & 447 & 291 & - & 95.5 \\
\hline & AbCellera clone & AbCellera clone & & & & AbCellera clone & AbCellera clone & & & & AbCellera clone & AbCellera clone & & \\
\hline 181 & 397 & 525 & - & 5 & 200 & 429 & 397 & - & J4 & 219 & 447 & 308 & - & 147 \\
\hline & AbCellera clone & Leinco clone & & & & AbCellera clone & AbCellera clone & & & & AbCellera clone & AbCellera clone & & \\
\hline 182 & 397 & 2136 & - & 357.5 & 201 & 429 & 429 & - & 422.5 & 220 & 447 & 310 & - & 329.5 \\
\hline & AbCellera clone & Leinco clone & & & & AbCellera clone & AbCellera clone & & & & AbCellera clone & AbCellera clone & & \\
\hline 183 & 397 & 2143 & - & 402.5 & 202 & 429 & 447 & - & 236 & 221 & 447 & 313 & - & 80.5 \\
\hline & AbCellera clone & Leinco clone & & & & AbCellera clone & AbCellera clone & & & & AbCellera clone & AbCellera clone & & \\
\hline 184 & 397 & 2146 & - & 479 & 203 & 429 & 459 & - & 128 & 222 & 447 & 353 & - & 192 \\
\hline & AbCellera clone & Leinco clone & & & & AbCellera clone & AbCellera clone & & & & AbCellera clone & AbCellera clone & & \\
\hline 185 & 397 & 2197 & - & 525.5 & 204 & 429 & 525 & - & 226 & 223 & 447 & 397 & - & 428.5 \\
\hline
\end{tabular}




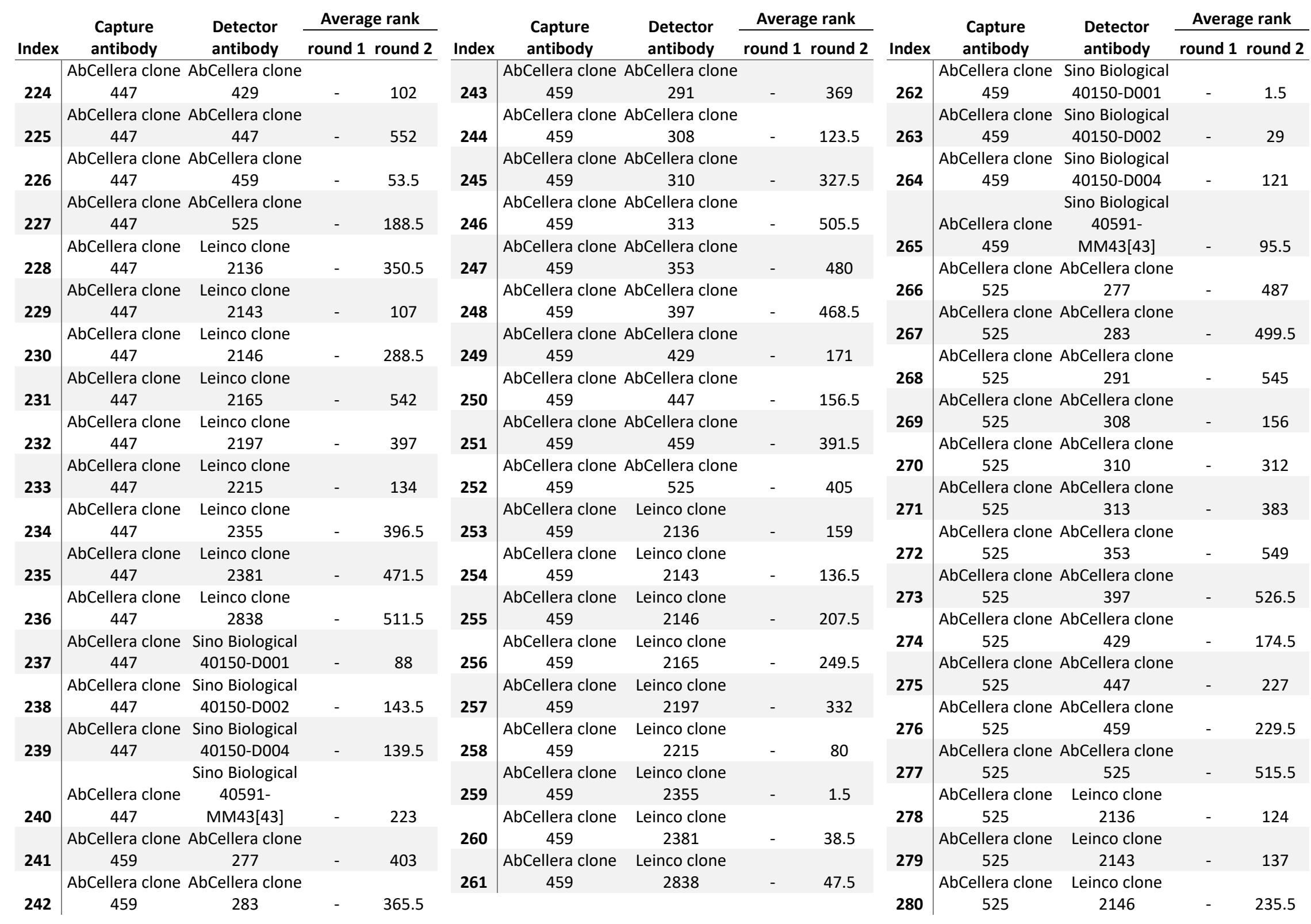




\begin{tabular}{|c|c|c|c|c|c|c|c|c|c|c|c|c|c|c|}
\hline \multirow[b]{2}{*}{ Index } & \multirow{2}{*}{$\begin{array}{l}\text { Capture } \\
\text { antibody }\end{array}$} & \multirow{2}{*}{$\begin{array}{l}\text { Detector } \\
\text { antibody }\end{array}$} & \multicolumn{2}{|c|}{ Average rank } & \multirow[b]{2}{*}{ Index } & \multirow{2}{*}{$\begin{array}{l}\text { Capture } \\
\text { antibody }\end{array}$} & \multirow{2}{*}{$\begin{array}{l}\text { Detector } \\
\text { antibody }\end{array}$} & \multicolumn{2}{|c|}{ Average rank } & \multirow[b]{2}{*}{ Index } & \multirow{2}{*}{$\begin{array}{l}\text { Capture } \\
\text { antibody }\end{array}$} & \multirow{2}{*}{$\begin{array}{l}\text { Detector } \\
\text { antibody }\end{array}$} & \multicolumn{2}{|c|}{ Average rank } \\
\hline & & & round 1 & round 2 & & & & round 1 & round 2 & & & & round 1 & round 2 \\
\hline 281 & $\begin{array}{c}\text { AbCellera clone } \\
525\end{array}$ & $\begin{array}{c}\text { Leinco clone } \\
2165\end{array}$ & - & 474.5 & & $\begin{array}{c}\text { CABT- } \\
\text { CS031[BIB112] }\end{array}$ & & & & & $\begin{array}{c}\text { Creative } \\
\text { Diagnostics }\end{array}$ & & & \\
\hline 282 & $\begin{array}{c}\text { AbCellera clone } \\
525\end{array}$ & $\begin{array}{c}\text { Leinco clone } \\
2197\end{array}$ & - & 292.5 & & $\begin{array}{c}\text { Creative } \\
\text { Diagnostics }\end{array}$ & & & & 305 & $\begin{array}{c}\text { CABT- } \\
\text { CS033[BIB114] }\end{array}$ & $\begin{array}{c}\text { Sino Biological } \\
\text { 40150-D004 }\end{array}$ & 12 & - \\
\hline 283 & $\begin{array}{c}\text { AbCellera clone } \\
525\end{array}$ & $\begin{array}{c}\text { Leinco clone } \\
2215\end{array}$ & - & 132 & 296 & $\begin{array}{c}\text { CABT- } \\
\text { CS031[BIB112] }\end{array}$ & $\begin{array}{c}\text { Sino Biological } \\
\text { 40150-D003 }\end{array}$ & 29.5 & - & & $\begin{array}{c}\text { Creative } \\
\text { Diagnostics }\end{array}$ & & & \\
\hline 284 & $\begin{array}{c}\text { AbCellera clone } \\
525\end{array}$ & $\begin{array}{l}\text { Leinco clone } \\
2355\end{array}$ & - & 9 & & $\begin{array}{c}\text { Creative } \\
\text { Diagnostics }\end{array}$ & & & & 306 & $\begin{array}{c}\text { CABT- } \\
\text { CS033[BIB114] }\end{array}$ & $\begin{array}{c}\text { Sino Biological } \\
40150-\text { R007 }\end{array}$ & 13 & - \\
\hline 285 & $\begin{array}{c}\text { AbCellera clone } \\
525\end{array}$ & $\begin{array}{c}\text { Leinco clone } \\
2381\end{array}$ & - & 75.5 & 297 & $\begin{array}{c}\text { CABT- } \\
\text { CS031[BIB112] }\end{array}$ & $\begin{array}{c}\text { Sino Biological } \\
\text { 40150-D004 }\end{array}$ & 11 & - & 307 & $\begin{array}{l}\text { Leinco clone } \\
2143\end{array}$ & $\begin{array}{c}\text { AbCellera clone } \\
277\end{array}$ & - & 536 \\
\hline 286 & $\begin{array}{c}\text { AbCellera clone } \\
525\end{array}$ & $\begin{array}{c}\text { Leinco clone } \\
2838\end{array}$ & - & 62.5 & & $\begin{array}{c}\text { Creative } \\
\text { Diagnostics }\end{array}$ & & & & 308 & $\begin{array}{c}\text { Leinco clone } \\
2143\end{array}$ & $\begin{array}{c}\text { AbCellera clone } \\
283\end{array}$ & - & 409 \\
\hline 287 & $\begin{array}{c}\text { AbCellera clone } \\
525\end{array}$ & $\begin{array}{c}\text { Sino Biological } \\
40150-D 001\end{array}$ & - & 59 & 298 & $\begin{array}{c}\text { CABT- } \\
\text { CS031[BIB112] }\end{array}$ & $\begin{array}{c}\text { Sino Biological } \\
40150-R 007\end{array}$ & 23 & - & 309 & $\begin{array}{c}\text { Leinco clone } \\
2143\end{array}$ & $\begin{array}{c}\text { AbCellera clone } \\
291\end{array}$ & - & 201.5 \\
\hline 288 & $\begin{array}{c}\text { AbCellera clone } \\
525\end{array}$ & $\begin{array}{c}\text { Sino Biological } \\
40150-D 002\end{array}$ & - & 29.5 & & $\begin{array}{c}\text { Creative } \\
\text { Diagnostics }\end{array}$ & & & & 310 & $\begin{array}{c}\text { Leinco clone } \\
2143\end{array}$ & $\begin{array}{l}\text { AbCellera clone } \\
308\end{array}$ & - & 267 \\
\hline 289 & $\begin{array}{c}\text { AbCellera clone } \\
525\end{array}$ & $\begin{array}{c}\text { Sino Biological } \\
40150-D 004\end{array}$ & - & 100 & 299 & $\begin{array}{c}\text { CABT- } \\
\text { CS033[BIB114] }\end{array}$ & $\begin{array}{c}\text { AbCellera clone } \\
131\end{array}$ & 39.5 & - & 311 & $\begin{array}{c}\text { Leinco clone } \\
2143\end{array}$ & $\begin{array}{c}\text { AbCellera clone } \\
310\end{array}$ & - & 562 \\
\hline & AbCellera clone & $\begin{array}{c}\text { Sino Biological } \\
40591-\end{array}$ & & & & $\begin{array}{l}\text { Creative } \\
\text { Diagnostics } \\
\text { CABT- }\end{array}$ & $\begin{array}{c}\text { Creative } \\
\text { Diagnostics } \\
\text { CABT- }\end{array}$ & & & 312 & $\begin{array}{l}\text { Leinco clone } \\
2143\end{array}$ & $\begin{array}{l}\text { AbCellera clone } \\
313\end{array}$ & - & 216.5 \\
\hline 290 & $\begin{array}{c}525 \\
\text { Creative }\end{array}$ & MM43[43] & - & 170.5 & 300 & $\begin{array}{c}\text { CABT- } \\
\text { CS033[BIB114] }\end{array}$ & $\begin{array}{c}\text { CABT- } \\
\text { CS031[BIB112] }\end{array}$ & 20.5 & - & 313 & $\begin{array}{c}\text { Leinco clone } \\
2143\end{array}$ & $\begin{array}{c}\text { AbCellera clone } \\
353\end{array}$ & - & 552 \\
\hline 291 & $\begin{array}{c}\text { Diagnostics } \\
\text { CABT- } \\
\text { CS031[BIB112] }\end{array}$ & $\begin{array}{c}\text { AbCellera clone } \\
131\end{array}$ & 32.5 & - & & $\begin{array}{c}\text { Creative } \\
\text { Diagnostics } \\
\text { CABT- }\end{array}$ & $\begin{array}{c}\text { Creative } \\
\text { Diagnostics } \\
\text { CABT- }\end{array}$ & & & 314 & $\begin{array}{l}\text { Leinco clone } \\
\qquad 2143 \\
\text { Leinco clone }\end{array}$ & $\begin{array}{l}\text { AbCellera clone } \\
397 \\
\text { AbCellera clone }\end{array}$ & - & 512 \\
\hline & Creative & Creative & & & 301 & CS033[BIB114] & CS033[BIB114] & 56 & - & 315 & 2143 & 429 & - & 317.5 \\
\hline & $\begin{array}{l}\text { Diagnostics } \\
\text { CABT- }\end{array}$ & $\begin{array}{c}\text { Diagnostics } \\
\text { CABT- }\end{array}$ & & & & $\begin{array}{c}\text { Creative } \\
\text { Diagnostics }\end{array}$ & & & & 316 & $\begin{array}{c}\text { Leinco clone } \\
2143\end{array}$ & $\begin{array}{l}\text { AbCellera clone } \\
447\end{array}$ & - & 281.5 \\
\hline 292 & $\begin{array}{c}\text { CS031[BIB112] } \\
\text { Creative }\end{array}$ & $\begin{array}{c}\text { CS031[BIB112] } \\
\text { Creative }\end{array}$ & 58 & - & 302 & $\begin{array}{c}\text { CABT- } \\
\text { CS033[BIB114] }\end{array}$ & $\begin{array}{c}\text { Sino Biological } \\
\text { 40150-D001 }\end{array}$ & 48 & - & 317 & $\begin{array}{c}\text { Leinco clone } \\
2143\end{array}$ & $\begin{array}{c}\text { AbCellera clone } \\
459\end{array}$ & - & 147 \\
\hline & $\begin{array}{c}\text { Diagnostics } \\
\text { CABT- }\end{array}$ & $\begin{array}{c}\text { Diagnostics } \\
\text { CABT- }\end{array}$ & & & & $\begin{array}{c}\text { Creative } \\
\text { Diagnostics }\end{array}$ & & & & 318 & $\begin{array}{c}\text { Leinco clone } \\
2143\end{array}$ & $\begin{array}{l}\text { AbCellera clone } \\
525\end{array}$ & - & 303 \\
\hline 293 & $\begin{array}{c}\text { CS031[BIB112] } \\
\text { Creative }\end{array}$ & CS033[BIB114] & 25 & - & 303 & $\begin{array}{c}\text { CABT- } \\
\text { CS033[BIB114] }\end{array}$ & $\begin{array}{c}\text { Sino Biological } \\
40150-D 002\end{array}$ & 49 & - & 319 & $\begin{array}{l}\text { Leinco clone } \\
2143\end{array}$ & $\begin{array}{l}\text { Leinco clone } \\
2136\end{array}$ & - & 264 \\
\hline & $\begin{array}{c}\text { Diagnostics } \\
\text { CABT- }\end{array}$ & Sino Biological & & & & $\begin{array}{c}\text { Creative } \\
\text { Diagnostics }\end{array}$ & & & & 320 & $\begin{array}{c}\text { Leinco clone } \\
2143\end{array}$ & $\begin{array}{c}\text { Leinco clone } \\
2143\end{array}$ & - & 520.5 \\
\hline 294 & CS031[BIB112] & 40150-D001 & 25 & - & & CABT- & Sino Biological & & & & Leinco clone & Leinco clone & & \\
\hline 295 & $\begin{array}{c}\text { Creative } \\
\text { Diagnostics }\end{array}$ & $\begin{array}{c}\text { Sino Biological } \\
40150-D 002\end{array}$ & 31 & - & 304 & CS033[BIB114] & 40150-D003 & 17 & - & 321 & 2143 & 2146 & - & 234 \\
\hline
\end{tabular}




\begin{tabular}{|c|c|c|c|c|c|c|c|c|c|c|c|c|c|c|}
\hline \multirow{3}{*}{ Index } & \multirow{2}{*}{$\begin{array}{l}\text { Capture } \\
\text { antibody }\end{array}$} & \multirow{2}{*}{$\begin{array}{l}\text { Detector } \\
\text { antibody }\end{array}$} & \multicolumn{2}{|c|}{ Average rank } & \multirow[b]{2}{*}{ Index } & \multirow{2}{*}{$\begin{array}{l}\text { Capture } \\
\text { antibody }\end{array}$} & \multirow{2}{*}{$\begin{array}{l}\text { Detector } \\
\text { antibody }\end{array}$} & \multicolumn{2}{|c|}{ Average rank } & \multirow[b]{2}{*}{ Index } & \multirow{2}{*}{$\begin{array}{l}\text { Capture } \\
\text { antibody }\end{array}$} & \multirow{2}{*}{$\begin{array}{l}\text { Detector } \\
\text { antibody }\end{array}$} & \multicolumn{2}{|c|}{ Average rank } \\
\hline & & & round 1 & round 2 & & & & round 1 & round 2 & & & & round 1 & round 2 \\
\hline & Leinco clone & Leinco clone & & & & Leinco clone & AbCellera clone & & & & Leinco clone & AbCellera clone & & \\
\hline \multirow[t]{2}{*}{322} & 2143 & 2165 & - & 527 & 341 & 2146 & 447 & - & 331 & 360 & 2149 & 308 & - & 286 \\
\hline & Leinco clone & Leinco clone & & & & Leinco clone & AbCellera clone & & & & Leinco clone & AbCellera clone & & \\
\hline \multirow[t]{2}{*}{323} & 2143 & 2197 & - & 547.5 & 342 & 2146 & 459 & - & 105.5 & 361 & 2149 & 310 & - & 537 \\
\hline & Leinco clone & Leinco clone & & & & Leinco clone & AbCellera clone & & & & Leinco clone & AbCellera clone & & \\
\hline \multirow[t]{2}{*}{324} & 2143 & 2215 & - & 179.5 & 343 & 2146 & 525 & - & 277.5 & 362 & 2149 & 313 & - & 281.5 \\
\hline & $\begin{array}{c}\text { Leinco clone } \\
2143\end{array}$ & $\begin{array}{c}\text { Leinco clone } \\
2355\end{array}$ & - & 104.5 & 344 & $\begin{array}{c}\text { Leinco clone } \\
2146\end{array}$ & $\begin{array}{l}\text { Leinco clone } \\
2136\end{array}$ & - & 385 & 363 & $\begin{array}{c}\text { Leinco clone } \\
2149\end{array}$ & $\begin{array}{c}\text { AbCellera clone } \\
353\end{array}$ & - & 547.5 \\
\hline 325 & Leinco clone & Leinco clone & & & & Leinco clone & Leinco clone & & & & Leinco clone & AbCellera clone & & \\
\hline 326 & 2143 & 2381 & - & 200.5 & 345 & 2146 & 2143 & - & 149 & 364 & 2149 & 397 & - & 559.5 \\
\hline \multirow[t]{2}{*}{327} & $\begin{array}{l}\text { Leinco clone } \\
2143\end{array}$ & $\begin{array}{l}\text { Leinco clone } \\
2838\end{array}$ & - & 181 & 346 & $\begin{array}{c}\text { Leinco clone } \\
2146\end{array}$ & $\begin{array}{l}\text { Leinco clone } \\
2146\end{array}$ & - & 547 & 365 & $\begin{array}{l}\text { Leinco clone } \\
2149\end{array}$ & $\begin{array}{l}\text { AbCellera clone } \\
429\end{array}$ & - & 373 \\
\hline & $\begin{array}{c}\text { Leinco clone } \\
2143\end{array}$ & $\begin{array}{c}\text { Sino Biological } \\
\text { 40150-D001 }\end{array}$ & - & 273 & 347 & $\begin{array}{c}\text { Leinco clone } \\
2146\end{array}$ & $\begin{array}{c}\text { Leinco clone } \\
\quad 2165\end{array}$ & - & 437.5 & 366 & $\begin{array}{c}\text { Leinco clone } \\
2149\end{array}$ & $\begin{array}{c}\text { AbCellera clone } \\
447\end{array}$ & - & 380 \\
\hline \multirow[t]{2}{*}{329} & $\begin{array}{l}\text { Leinco clone } \\
2143\end{array}$ & $\begin{array}{l}\text { Sino Biological } \\
40150-\mathrm{D} 002\end{array}$ & - & 171 & 348 & $\begin{array}{c}\text { Leinco clone } \\
2146\end{array}$ & $\begin{array}{l}\text { Leinco clone } \\
2197\end{array}$ & - & 300 & 367 & $\begin{array}{l}\text { Leinco clone } \\
2149\end{array}$ & $\begin{array}{l}\text { AbCellera clone } \\
459\end{array}$ & - & 230.5 \\
\hline & $\begin{array}{c}\text { Leinco clone } \\
2143\end{array}$ & $\begin{array}{c}\text { Sino Biological } \\
\text { 40150-D004 }\end{array}$ & - & 379 & 349 & $\begin{array}{c}\text { Leinco clone } \\
2146\end{array}$ & $\begin{array}{c}\text { Leinco clone } \\
2215\end{array}$ & - & 397 & 368 & $\begin{array}{c}\text { Leinco clone } \\
2149\end{array}$ & $\begin{array}{l}\text { AbCellera clone } \\
525\end{array}$ & - & 308.5 \\
\hline 330 & $\begin{array}{l}\text { Leinco clone } \\
2146\end{array}$ & $\begin{array}{c}\text { AbCellera clone } \\
277\end{array}$ & - & 521.5 & 350 & $\begin{array}{c}\text { Leinco clone } \\
2146\end{array}$ & $\begin{array}{c}\text { Leinco clone } \\
2355\end{array}$ & - & 140.5 & 369 & $\begin{array}{c}\text { Leinco clone } \\
2149\end{array}$ & $\begin{array}{l}\text { Leinco clone } \\
2136\end{array}$ & - & 419.5 \\
\hline 331 & Leinco clone & AbCellera clone & & & & Leinco clone & Leinco clone & & & & Leinco clone & Leinco clone & & \\
\hline \multirow[t]{2}{*}{332} & 2146 & 283 & - & 456 & 351 & 2146 & 2381 & - & 170.5 & 370 & 2149 & 2143 & - & 345.5 \\
\hline & $\begin{array}{l}\text { Leinco clone } \\
2146\end{array}$ & $\begin{array}{c}\text { AbCellera clone } \\
291\end{array}$ & 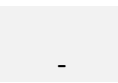 & 349 & 352 & $\begin{array}{c}\text { Leinco clone } \\
2146\end{array}$ & $\begin{array}{c}\text { Leinco clone } \\
2838\end{array}$ & - & 114.5 & 371 & $\begin{array}{c}\text { Leinco clone } \\
2149\end{array}$ & $\begin{array}{l}\text { Leinco clone } \\
2146\end{array}$ & - & 476.5 \\
\hline 333 & Leinco clone & AbCellera clone & & & & Leinco clone & Sino Biological & & & & Leinco clone & Leinco clone & & \\
\hline 334 & 2146 & 308 & - & 262 & 353 & 2146 & 40150-D001 & - & 384.5 & 372 & 2149 & 2165 & - & 497 \\
\hline \multirow[t]{2}{*}{335} & $\begin{array}{l}\text { Leinco clone } \\
2146\end{array}$ & $\begin{array}{c}\text { AbCellera clone } \\
310\end{array}$ & 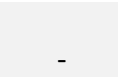 & 425.5 & 354 & $\begin{array}{c}\text { Leinco clone } \\
2146\end{array}$ & $\begin{array}{c}\text { Sino Biological } \\
40150-D 002\end{array}$ & - & 336 & 373 & $\begin{array}{c}\text { Leinco clone } \\
2149\end{array}$ & $\begin{array}{c}\text { Leinco clone } \\
2197\end{array}$ & - & 539 \\
\hline & Leinco clone & AbCellera clone & & & & Leinco clone & Sino Biological & & & & Leinco clone & Leinco clone & & \\
\hline 336 & 2146 & 313 & - & 331.5 & 355 & 2146 & 40150-D004 & - & 19 & 374 & 2149 & 2215 & - & 226.5 \\
\hline 337 & $\begin{array}{l}\text { Leinco clone } \\
2146\end{array}$ & $\begin{array}{l}\text { AbCellera clone } \\
\quad 353\end{array}$ & - & 323.5 & & Leinco clone & $\begin{array}{c}\text { Sino Biological } \\
\text { 40591- }\end{array}$ & & & 375 & $\begin{array}{c}\text { Leinco clone } \\
2149\end{array}$ & $\begin{array}{l}\text { Leinco clone } \\
2355\end{array}$ & - & 114 \\
\hline & Leinco clone & AbCellera clone & & & 356 & 2146 & MM43[43] & - & 321 & & Leinco clone & Leinco clone & & \\
\hline 338 & 2146 & 397 & - & 437 & & Leinco clone & AbCellera clone & & & 376 & 2149 & 2381 & - & 275.5 \\
\hline & Leinco clone & AbCellera clone & & & 357 & 2149 & 277 & - & 407.5 & & Leinco clone & Leinco clone & & \\
\hline 339 & 2146 & 415 & - & 542.5 & & Leinco clone & AbCellera clone & & & 377 & 2149 & 2838 & - & 208.5 \\
\hline & Leinco clone & AbCellera clone & & & 358 & 2149 & 283 & - & 454.5 & & Leinco clone & Sino Biological & & \\
\hline 340 & 2146 & 429 & - & 306 & 359 & $\begin{array}{c}\text { Leinco clone } \\
2149\end{array}$ & $\begin{array}{c}\text { AbCellera clone } \\
291\end{array}$ & - & 475.5 & 378 & 2149 & 40150-D001 & - & 258 \\
\hline
\end{tabular}




\begin{tabular}{|c|c|c|c|c|c|c|c|c|c|c|c|c|c|c|}
\hline \multirow[b]{2}{*}{ Index } & \multirow{2}{*}{$\begin{array}{l}\text { Capture } \\
\text { antibody }\end{array}$} & \multirow{2}{*}{$\begin{array}{l}\text { Detector } \\
\text { antibody }\end{array}$} & \multicolumn{2}{|c|}{ Average rank } & \multirow[b]{2}{*}{ Index } & \multirow{2}{*}{$\begin{array}{l}\text { Capture } \\
\text { antibody }\end{array}$} & \multirow{2}{*}{$\begin{array}{l}\text { Detector } \\
\text { antibody }\end{array}$} & \multicolumn{2}{|c|}{ Average rank } & \multirow[b]{2}{*}{ Index } & \multirow{2}{*}{$\begin{array}{l}\text { Capture } \\
\text { antibody }\end{array}$} & \multirow{2}{*}{$\begin{array}{l}\text { Detector } \\
\text { antibody }\end{array}$} & \multicolumn{2}{|c|}{ Average rank } \\
\hline & & & round 1 & round 2 & & & & round 1 & 1 round 2 & & & & round 1 & round 2 \\
\hline 379 & $\begin{array}{c}\text { Leinco clone } \\
2149\end{array}$ & $\begin{array}{c}\text { Sino Biological } \\
40150-D 002\end{array}$ & - & 192.5 & 398 & $\begin{array}{c}\text { Leinco clone } \\
2165\end{array}$ & $\begin{array}{c}\text { Leinco clone } \\
2215\end{array}$ & - & 281 & 417 & $\begin{array}{c}\text { Leinco clone } \\
2215\end{array}$ & $\begin{array}{c}\text { AbCellera clone } \\
525\end{array}$ & - & 300.5 \\
\hline 380 & $\begin{array}{c}\text { Leinco clone } \\
2149\end{array}$ & $\begin{array}{c}\text { Sino Biological } \\
40150-D 004\end{array}$ & - & 217.5 & 399 & $\begin{array}{l}\text { Leinco clone } \\
2165\end{array}$ & $\begin{array}{c}\text { Leinco clone } \\
2355\end{array}$ & - & 529 & 418 & $\begin{array}{c}\text { Leinco clone } \\
2215\end{array}$ & $\begin{array}{c}\text { Leinco clone } \\
2136\end{array}$ & - & 433 \\
\hline 381 & $\begin{array}{c}\text { Leinco clone } \\
2165\end{array}$ & $\begin{array}{c}\text { AbCellera clone } \\
277\end{array}$ & - & 530 & 400 & $\begin{array}{c}\text { Leinco clone } \\
2165\end{array}$ & $\begin{array}{c}\text { Leinco clone } \\
2381\end{array}$ & - & 500.5 & 419 & $\begin{array}{c}\text { Leinco clone } \\
2215\end{array}$ & $\begin{array}{c}\text { Leinco clone } \\
2143\end{array}$ & - & 133 \\
\hline 382 & $\begin{array}{c}\text { Leinco clone } \\
2165\end{array}$ & $\begin{array}{c}\text { AbCellera clone } \\
283\end{array}$ & - & 380 & 401 & $\begin{array}{c}\text { Leinco clone } \\
2165\end{array}$ & $\begin{array}{c}\text { Leinco clone } \\
2838\end{array}$ & - & 537.5 & 420 & $\begin{array}{c}\text { Leinco clone } \\
2215\end{array}$ & $\begin{array}{c}\text { Leinco clone } \\
2146\end{array}$ & - & 462 \\
\hline 383 & $\begin{array}{c}\text { Leinco clone } \\
2165\end{array}$ & $\begin{array}{c}\text { AbCellera clone } \\
291\end{array}$ & - & 214 & 402 & $\begin{array}{c}\text { Leinco clone } \\
2165\end{array}$ & $\begin{array}{c}\text { Sino Biological } \\
\text { 40150-D001 }\end{array}$ & - & 274 & 421 & $\begin{array}{c}\text { Leinco clone } \\
2215\end{array}$ & $\begin{array}{c}\text { Leinco clone } \\
2197\end{array}$ & - & 428 \\
\hline 384 & $\begin{array}{c}\text { Leinco clone } \\
2165\end{array}$ & $\begin{array}{l}\text { AbCellera clone } \\
308\end{array}$ & - & 222.5 & 403 & $\begin{array}{c}\text { Leinco clone } \\
2165\end{array}$ & $\begin{array}{c}\text { Sino Biological } \\
\text { 40150-D002 }\end{array}$ & - & 230 & 422 & $\begin{array}{c}\text { Leinco clone } \\
2215\end{array}$ & $\begin{array}{c}\text { Leinco clone } \\
2215\end{array}$ & - & 484 \\
\hline 385 & $\begin{array}{c}\text { Leinco clone } \\
2165\end{array}$ & $\begin{array}{c}\text { AbCellera clone } \\
310\end{array}$ & - & 483 & 404 & $\begin{array}{c}\text { Leinco clone } \\
2165\end{array}$ & $\begin{array}{c}\text { Sino Biological } \\
\text { 40150-D004 }\end{array}$ & - & 235.5 & 423 & $\begin{array}{c}\text { Leinco clone } \\
2215\end{array}$ & $\begin{array}{c}\text { Leinco clone } \\
2355\end{array}$ & - & 92.5 \\
\hline 386 & $\begin{array}{c}\text { Leinco clone } \\
2165\end{array}$ & $\begin{array}{c}\text { AbCellera clone } \\
313\end{array}$ & - & 176 & 405 & $\begin{array}{c}\text { Leinco clone } \\
2215\end{array}$ & $\begin{array}{c}\text { AbCellera clone } \\
277\end{array}$ & - & 285.5 & 424 & $\begin{array}{c}\text { Leinco clone } \\
2215\end{array}$ & $\begin{array}{c}\text { Leinco clone } \\
2381\end{array}$ & - & 107 \\
\hline 387 & $\begin{array}{c}\text { Leinco clone } \\
2165\end{array}$ & $\begin{array}{c}\text { AbCellera clone } \\
\quad 353\end{array}$ & - & 327.5 & 406 & $\begin{array}{c}\text { Leinco clone } \\
2215\end{array}$ & $\begin{array}{l}\text { AbCellera clone } \\
283\end{array}$ & - & 369.5 & 425 & $\begin{array}{c}\text { Leinco clone } \\
2215\end{array}$ & $\begin{array}{c}\text { Leinco clone } \\
2838\end{array}$ & - & 70.5 \\
\hline 388 & $\begin{array}{c}\text { Leinco clone } \\
2165\end{array}$ & $\begin{array}{c}\text { AbCellera clone } \\
397\end{array}$ & - & 477 & 407 & $\begin{array}{c}\text { Leinco clone } \\
2215\end{array}$ & $\begin{array}{c}\text { AbCellera clone } \\
291\end{array}$ & - & 140 & 426 & $\begin{array}{c}\text { Leinco clone } \\
2215\end{array}$ & $\begin{array}{c}\text { Sino Biological } \\
40150-D 001\end{array}$ & - & 296 \\
\hline 389 & $\begin{array}{c}\text { Leinco clone } \\
2165\end{array}$ & $\begin{array}{c}\text { AbCellera clone } \\
429\end{array}$ & - & 226.5 & 408 & $\begin{array}{c}\text { Leinco clone } \\
2215\end{array}$ & $\begin{array}{l}\text { AbCellera clone } \\
308\end{array}$ & - & 139 & 427 & $\begin{array}{c}\text { Leinco clone } \\
2215\end{array}$ & $\begin{array}{c}\text { Sino Biological } \\
40150-D 002\end{array}$ & - & 321.5 \\
\hline 390 & $\begin{array}{c}\text { Leinco clone } \\
2165\end{array}$ & $\begin{array}{c}\text { AbCellera clone } \\
447\end{array}$ & - & 524.5 & 409 & $\begin{array}{c}\text { Leinco clone } \\
2215\end{array}$ & $\begin{array}{c}\text { AbCellera clone } \\
310\end{array}$ & - & 361.5 & 428 & $\begin{array}{c}\text { Leinco clone } \\
2215\end{array}$ & $\begin{array}{c}\text { Sino Biological } \\
40150-D 004\end{array}$ & - & 174.5 \\
\hline 391 & $\begin{array}{c}\text { Leinco clone } \\
2165\end{array}$ & $\begin{array}{c}\text { AbCellera clone } \\
459\end{array}$ & - & $14 . J$ & 410 & $\begin{array}{c}\text { Leinco clone } \\
2215\end{array}$ & $\begin{array}{c}\text { AbCellera clone } \\
313\end{array}$ & - & 147.5 & 429 & $\begin{array}{c}\text { Leinco clone } \\
2355\end{array}$ & $\begin{array}{c}\text { AbCellera clone } \\
277\end{array}$ & - & 210.5 \\
\hline 392 & $\begin{array}{l}\text { Leinco clone } \\
2165\end{array}$ & $\begin{array}{l}\text { AbCellera clone } \\
525\end{array}$ & - & 279.5 & 411 & $\begin{array}{l}\text { Leinco clone } \\
2215\end{array}$ & $\begin{array}{c}\text { AbCellera clone } \\
353\end{array}$ & - & 388 & 430 & $\begin{array}{l}\text { Leinco clone } \\
2355\end{array}$ & $\begin{array}{l}\text { AbCellera clone } \\
283\end{array}$ & - & 266 \\
\hline 393 & $\begin{array}{c}\text { Leinco clone } \\
2165\end{array}$ & $\begin{array}{l}\text { Leinco clone } \\
2136\end{array}$ & - & 462.5 & 412 & $\begin{array}{c}\text { Leinco clone } \\
2215\end{array}$ & $\begin{array}{c}\text { AbCellera clone } \\
397\end{array}$ & - & 379 & 431 & $\begin{array}{c}\text { Leinco clone } \\
2355\end{array}$ & $\begin{array}{c}\text { AbCellera clone } \\
291\end{array}$ & - & 35.5 \\
\hline 394 & $\begin{array}{l}\text { Leinco clone } \\
2165\end{array}$ & $\begin{array}{c}\text { Leinco clone } \\
2143\end{array}$ & - & 255.5 & 413 & $\begin{array}{l}\text { Leinco clone } \\
2215\end{array}$ & $\begin{array}{l}\text { AbCellera clone } \\
415\end{array}$ & - & 322 & 432 & $\begin{array}{l}\text { Leinco clone } \\
2355\end{array}$ & $\begin{array}{l}\text { AbCellera clone } \\
308\end{array}$ & - & 58.5 \\
\hline 395 & $\begin{array}{c}\text { Leinco clone } \\
2165\end{array}$ & $\begin{array}{c}\text { Leinco clone } \\
2146\end{array}$ & - & 280.5 & 414 & $\begin{array}{l}\text { Leinco clone } \\
2215\end{array}$ & $\begin{array}{c}\text { AbCellera clone } \\
429\end{array}$ & - & 256 & 433 & $\begin{array}{c}\text { Leinco clone } \\
2355\end{array}$ & $\begin{array}{l}\text { AbCellera clone } \\
310\end{array}$ & - & 210 \\
\hline 396 & $\begin{array}{c}\text { Leinco clone } \\
2165\end{array}$ & $\begin{array}{c}\text { Leinco clone } \\
2165\end{array}$ & - & 404.5 & 415 & $\begin{array}{c}\text { Leinco clone } \\
2215\end{array}$ & $\begin{array}{l}\text { AbCellera clone } \\
447\end{array}$ & - & 235 & 434 & $\begin{array}{c}\text { Leinco clone } \\
2355\end{array}$ & $\begin{array}{l}\text { AbCellera clone } \\
\quad 313\end{array}$ & - & 61.5 \\
\hline 397 & $\begin{array}{c}\text { Leinco clone } \\
2165\end{array}$ & $\begin{array}{c}\text { Leinco clone } \\
2197\end{array}$ & - & 551.5 & 416 & $\begin{array}{c}\text { Leinco clone } \\
2215\end{array}$ & $\begin{array}{c}\text { AbCellera clone } \\
459\end{array}$ & - & 27 & 435 & $\begin{array}{l}\text { Leinco clone } \\
2355\end{array}$ & $\begin{array}{c}\text { AbCellera clone } \\
353\end{array}$ & - & 454.5 \\
\hline
\end{tabular}




\begin{tabular}{|c|c|c|c|c|c|c|c|c|c|c|c|c|c|c|}
\hline \multirow{3}{*}{ Index } & \multirow{2}{*}{$\begin{array}{l}\text { Capture } \\
\text { antibody }\end{array}$} & \multirow{2}{*}{$\begin{array}{l}\text { Detector } \\
\text { antibody }\end{array}$} & \multicolumn{2}{|c|}{ Average rank } & \multirow[b]{2}{*}{ Index } & \multirow{2}{*}{$\begin{array}{l}\text { Capture } \\
\text { antibody }\end{array}$} & \multirow{2}{*}{$\begin{array}{l}\text { Detector } \\
\text { antibody }\end{array}$} & \multicolumn{2}{|c|}{ Average rank } & \multirow[b]{2}{*}{ Index } & \multirow{2}{*}{$\begin{array}{l}\text { Capture } \\
\text { antibody }\end{array}$} & \multirow{2}{*}{$\begin{array}{l}\text { Detector } \\
\text { antibody }\end{array}$} & \multicolumn{2}{|c|}{ Average rank } \\
\hline & & & round 1 & round 2 & & & & round 1 & round 2 & & & & round 1 & round 2 \\
\hline & Leinco clone & AbCellera clone & & & & Leinco clone & AbCellera clone & & & & Leinco clone & Leinco clone & & \\
\hline \multirow[t]{2}{*}{436} & 2355 & 397 & - & 559.5 & 455 & 2381 & 291 & - & 119.5 & 474 & 2381 & 2838 & - & 445 \\
\hline & $\begin{array}{l}\text { Leinco clone } \\
2355\end{array}$ & $\begin{array}{l}\text { AbCellera clone } \\
\quad 415\end{array}$ & - & 364 & 456 & $\begin{array}{c}\text { Leinco clone } \\
2381\end{array}$ & $\begin{array}{l}\text { AbCellera clone } \\
308\end{array}$ & - & 101.5 & 475 & $\begin{array}{c}\text { Leinco clone } \\
2381\end{array}$ & $\begin{array}{c}\text { Sino Biological } \\
40150-D 001\end{array}$ & - & 103 \\
\hline 437 & $\begin{array}{l}\text { Leinco clone } \\
2355\end{array}$ & $\begin{array}{l}\text { AbCellera clone } \\
429\end{array}$ & - & 95 & 457 & $\begin{array}{l}\text { Leinco clone } \\
2381\end{array}$ & $\begin{array}{l}\text { AbCellera clone } \\
\quad 310\end{array}$ & - & 311 & 476 & $\begin{array}{c}\text { Leinco clone } \\
2381\end{array}$ & $\begin{array}{c}\text { Sino Biological } \\
\text { 40150-D002 }\end{array}$ & - & 190 \\
\hline 438 & $\begin{array}{l}\text { Leinco clone } \\
2355\end{array}$ & $\begin{array}{c}\text { AbCellera clone } \\
447\end{array}$ & - & 437 & 458 & $\begin{array}{c}\text { Leinco clone } \\
2381\end{array}$ & $\begin{array}{l}\text { AbCellera clone } \\
313\end{array}$ & - & 90.5 & 477 & $\begin{array}{c}\text { Leinco clone } \\
2381\end{array}$ & $\begin{array}{c}\text { Sino Biological } \\
\text { 40150-D004 }\end{array}$ & - & 101.5 \\
\hline \multirow[t]{2}{*}{440} & $\begin{array}{l}\text { Leinco clone } \\
2355\end{array}$ & $\begin{array}{l}\text { AbCellera clone } \\
\qquad 459\end{array}$ & - & 5.5 & 459 & $\begin{array}{l}\text { Leinco clone } \\
2381\end{array}$ & $\begin{array}{c}\text { AbCellera clone } \\
353\end{array}$ & - & 329.5 & & Leinco clone & $\begin{array}{c}\text { Sino Biological } \\
40591-\end{array}$ & & \\
\hline & Leinco clone & AbCellera clone & & & & Leinco clone & AbCellera clone & & & 478 & 2381 & MM43[43] & - & 118.5 \\
\hline \multirow[t]{2}{*}{441} & 2355 & 525 & - & 104 & 460 & 2381 & 397 & - & 481.5 & & Leinco clone & AbCellera clone & & \\
\hline & Leinco clone & Leinco clone & & & & Leinco clone & AbCellera clone & & & 479 & 2838 & 277 & - & 345 \\
\hline \multirow[t]{2}{*}{442} & 2355 & 2136 & - & 201 & 461 & 2381 & 415 & - & 208 & & Leinco clone & AbCellera clone & & \\
\hline & Leinco clone & Leinco clone & & & & Leinco clone & AbCellera clone & & & 480 & 2838 & 283 & - & 257 \\
\hline \multirow[t]{2}{*}{443} & 2355 & 2143 & - & 55 & 462 & 2381 & 429 & - & 168 & & Leinco clone & AbCellera clone & & \\
\hline & Leinco clone & Leinco clone & & & & Leinco clone & AbCellera clone & & & 481 & 2838 & 291 & - & 123 \\
\hline \multirow[t]{2}{*}{444} & 2355 & 2146 & - & 233.5 & 463 & 2381 & 447 & - & 502 & & Leinco clone & AbCellera clone & & \\
\hline & Leinco clone & Leinco clone & & & & Leinco clone & AbCellera clone & & & 482 & 2838 & 308 & - & 61 \\
\hline \multirow[t]{2}{*}{445} & 2355 & 2197 & - & 162 & 464 & 2381 & 459 & - & 25.5 & & Leinco clone & AbCellera clone & & \\
\hline & Leinco clone & Leinco clone & & & & Leinco clone & AbCellera clone & & & 483 & 2838 & 310 & - & 449.5 \\
\hline \multirow[t]{2}{*}{446} & 2355 & 2215 & - & 175 & 465 & 2381 & 525 & - & 217.5 & & Leinco clone & AbCellera clone & & \\
\hline & Leinco clone & Leinco clone & & & & Leinco clone & Leinco clone & & & 484 & 2838 & 313 & - & 70 \\
\hline 447 & 2355 & 2355 & - & 304.5 & 466 & 2381 & 2136 & - & 219 & & Leinco clone & AbCellera clone & & \\
\hline & Leinco clone & Leinco clone & & & & Leinco clone & Leinco clone & & & 485 & 2838 & 353 & - & 300.5 \\
\hline 448 & 2355 & 2381 & - & 315 & 467 & 2381 & 2143 & - & 9 & & Leinco clone & AbCellera clone & & \\
\hline & Leinco clone & Leinco clone & & & & Leinco clone & Leinco clone & & & 486 & 2838 & 397 & - & 497.5 \\
\hline 449 & 2355 & 2838 & - & 429 & 468 & 2381 & 2146 & - & 255.5 & & Leinco clone & AbCellera clone & & \\
\hline & Leinco clone & Sino Biological & & & & Leinco clone & Leinco clone & & & 487 & 2838 & 415 & - & 284 \\
\hline 450 & 2355 & 40150-D001 & - & 65.5 & 469 & 2381 & 2165 & - & 429.5 & & Leinco clone & AbCellera clone & & \\
\hline & Leinco clone & Sino Biological & & & & Leinco clone & Leinco clone & & & 488 & 2838 & 429 & - & 166.5 \\
\hline 451 & 2355 & 40150-D002 & - & 78 & 470 & 2381 & 2197 & - & 205.5 & & Leinco clone & AbCellera clone & & \\
\hline & Leinco clone & Sino Biological & & & & Leinco clone & Leinco clone & & & 489 & 2838 & 447 & - & 480 \\
\hline 452 & 2355 & 40150-D004 & - & 64.5 & 471 & 2381 & 2215 & - & 274 & & Leinco clone & AbCellera clone & & \\
\hline & Leinco clone & AbCellera clone & & & & Leinco clone & Leinco clone & & & 490 & 2838 & 459 & - & 20 \\
\hline 453 & 2381 & 277 & - & 347.5 & 472 & 2381 & 2355 & - & 339.5 & & Leinco clone & AbCellera clone & & \\
\hline & Leinco clone & AbCellera clone & & & & Leinco clone & Leinco clone & & & 491 & 2838 & 525 & - & 186.5 \\
\hline 454 & 2381 & 283 & - & 295 & 473 & 2381 & 2381 & - & 428 & & Leinco clone & Leinco clone & & \\
\hline & & & & & & & & & & 492 & 2838 & 2136 & - & 199.5 \\
\hline
\end{tabular}




\begin{tabular}{|c|c|c|c|c|c|c|c|c|c|c|c|c|c|c|}
\hline \multirow[b]{2}{*}{ Index } & \multirow{2}{*}{$\begin{array}{l}\text { Capture } \\
\text { antibody }\end{array}$} & \multirow{2}{*}{$\begin{array}{l}\text { Detector } \\
\text { antibody }\end{array}$} & \multicolumn{2}{|c|}{ Average rank } & \multirow[b]{2}{*}{ Index } & \multirow{2}{*}{$\begin{array}{l}\text { Capture } \\
\text { antibody }\end{array}$} & \multirow{2}{*}{$\begin{array}{l}\text { Detector } \\
\text { antibody }\end{array}$} & \multicolumn{2}{|c|}{ Average rank } & \multirow[b]{2}{*}{ Index } & \multirow{2}{*}{$\begin{array}{l}\text { Capture } \\
\text { antibody }\end{array}$} & \multirow{2}{*}{$\begin{array}{l}\text { Detector } \\
\text { antibody }\end{array}$} & \multicolumn{2}{|c|}{ Average rank } \\
\hline & & & round 1 & round 2 & & & & round 1 & round 2 & & & & round 1 & round 2 \\
\hline 493 & $\begin{array}{c}\text { Leinco clone } \\
2838\end{array}$ & $\begin{array}{c}\text { Leinco clone } \\
2143\end{array}$ & - & 81.5 & 510 & $\begin{array}{c}\text { Sino Biological } \\
40150-D 001\end{array}$ & $\begin{array}{c}\text { Sino Biological } \\
40150-D 003\end{array}$ & 9 & - & 527 & $\begin{array}{l}\text { Sino Biological } \\
40150-D 002\end{array}$ & $\begin{array}{c}\text { Leinco clone } \\
2146\end{array}$ & - & 358 \\
\hline 494 & $\begin{array}{c}\text { Leinco clone } \\
2838\end{array}$ & $\begin{array}{c}\text { Leinco clone } \\
2146\end{array}$ & - & 224 & 511 & $\begin{array}{c}\text { Sino Biological } \\
40150-D 001\end{array}$ & $\begin{array}{c}\text { Sino Biological } \\
\text { 40150-D004 }\end{array}$ & 3 & - & 528 & $\begin{array}{l}\text { Sino Biological } \\
40150-D 002\end{array}$ & $\begin{array}{c}\text { Leinco clone } \\
2165\end{array}$ & - & 386 \\
\hline 495 & $\begin{array}{c}\text { Leinco clone } \\
2838\end{array}$ & $\begin{array}{c}\text { Leinco clone } \\
2165\end{array}$ & - & 446 & 512 & $\begin{array}{c}\text { Sino Biological } \\
40150-D 001\end{array}$ & $\begin{array}{c}\text { Sino Biological } \\
40150-R 007\end{array}$ & 16.5 & - & 529 & $\begin{array}{c}\text { Sino Biological } \\
40150-D 002\end{array}$ & $\begin{array}{c}\text { Leinco clone } \\
2197\end{array}$ & - & 276 \\
\hline 496 & $\begin{array}{c}\text { Leinco clone } \\
2838\end{array}$ & $\begin{array}{c}\text { Leinco clone } \\
2197\end{array}$ & - & 137 & 513 & $\begin{array}{l}\text { Sino Biological } \\
40150-D 002\end{array}$ & $\begin{array}{c}\text { AbCellera clone } \\
131\end{array}$ & 61 & - & 530 & $\begin{array}{l}\text { Sino Biological } \\
40150-D 002\end{array}$ & $\begin{array}{l}\text { Leinco clone } \\
2215\end{array}$ & - & 265 \\
\hline 497 & $\begin{array}{c}\text { Leinco clone } \\
2838\end{array}$ & $\begin{array}{l}\text { Leinco clone } \\
2215\end{array}$ & - & 171.5 & 514 & $\begin{array}{l}\text { Sino Biological } \\
40150-D 002\end{array}$ & $\begin{array}{c}\text { AbCellera clone } \\
277\end{array}$ & - & 379.5 & 531 & $\begin{array}{l}\text { Sino Biological } \\
40150-D 002\end{array}$ & $\begin{array}{c}\text { Leinco clone } \\
2355\end{array}$ & - & 67 \\
\hline 498 & $\begin{array}{c}\text { Leinco clone } \\
2838\end{array}$ & $\begin{array}{l}\text { Leinco clone } \\
2355\end{array}$ & - & 351.5 & 515 & $\begin{array}{c}\text { Sino Biological } \\
40150-D 002\end{array}$ & $\begin{array}{l}\text { AbCellera clone } \\
283\end{array}$ & - & 402 & 532 & $\begin{array}{l}\text { Sino Biological } \\
40150-D 002\end{array}$ & $\begin{array}{l}\text { Leinco clone } \\
2381\end{array}$ & - & 81.5 \\
\hline 499 & $\begin{array}{c}\text { Leinco clone } \\
2838\end{array}$ & $\begin{array}{c}\text { Leinco clone } \\
2381\end{array}$ & - & 356.5 & 516 & $\begin{array}{c}\text { Sino Biological } \\
40150-D 002\end{array}$ & $\begin{array}{l}\text { AbCellera clone } \\
291\end{array}$ & - & 218 & 533 & $\begin{array}{l}\text { Sino Biological } \\
40150-D 002\end{array}$ & $\begin{array}{c}\text { Leinco clone } \\
2838\end{array}$ & - & 126.5 \\
\hline 500 & $\begin{array}{c}\text { Leinco clone } \\
2838\end{array}$ & $\begin{array}{c}\text { Leinco clone } \\
2838\end{array}$ & - & 440 & 517 & $\begin{array}{c}\text { Sino Biological } \\
40150-D 002\end{array}$ & $\begin{array}{l}\text { AbCellera clone } \\
308\end{array}$ & - & 282.5 & 534 & $\begin{array}{l}\text { Sino Biological } \\
40150-D 002\end{array}$ & $\begin{array}{c}\text { Sino Biological } \\
\text { 40150-D001 }\end{array}$ & 32.5 & 420.5 \\
\hline 501 & $\begin{array}{c}\text { Leinco clone } \\
2838\end{array}$ & $\begin{array}{c}\text { Sino Biological } \\
\text { 40150-D001 }\end{array}$ & - & 69.5 & 518 & $\begin{array}{c}\text { Sino Biological } \\
\text { 40150-D002 }\end{array}$ & $\begin{array}{l}\text { AbCellera clone } \\
\quad 310\end{array}$ & - & 522 & 535 & $\begin{array}{c}\text { Sino Biological } \\
40150-D 002\end{array}$ & $\begin{array}{c}\text { Sino Biological } \\
40150-D 002\end{array}$ & 21 & 394 \\
\hline 502 & $\begin{array}{c}\text { Leinco clone } \\
2838\end{array}$ & $\begin{array}{l}\text { Sino Biological } \\
40150-D 002\end{array}$ & - & 91 & 519 & $\begin{array}{l}\text { Sino Biological } \\
40150-D 002\end{array}$ & $\begin{array}{c}\text { AbCellera clone } \\
313\end{array}$ & - & 156 & 536 & $\begin{array}{l}\text { Sino Biological } \\
40150-D 002\end{array}$ & $\begin{array}{c}\text { Sino Biological } \\
40150-D 003\end{array}$ & 10 & - \\
\hline 503 & $\begin{array}{c}\text { Leinco clone } \\
2838\end{array}$ & $\begin{array}{c}\text { Sino Biological } \\
\text { 40150-D004 }\end{array}$ & - & 98 & 520 & $\begin{array}{c}\text { Sino Biological } \\
\text { 40150-D002 }\end{array}$ & $\begin{array}{c}\text { AbCellera clone } \\
353\end{array}$ & - & 350 & 537 & $\begin{array}{l}\text { Sino Biological } \\
\text { 40150-D002 }\end{array}$ & $\begin{array}{c}\text { Sino Biological } \\
\text { 40150-D004 }\end{array}$ & 6.5 & 147 \\
\hline & Leinco clone & $\begin{array}{c}\text { Sino Biological } \\
40591-\end{array}$ & & & 521 & $\begin{array}{l}\text { Sino Biological } \\
40150-D 002\end{array}$ & $\begin{array}{c}\text { AbCellera clone } \\
397\end{array}$ & - & 512.5 & 538 & $\begin{array}{l}\text { Sino Biological } \\
40150-D 002\end{array}$ & $\begin{array}{c}\text { Sino Biological } \\
40150-\text { R007 }\end{array}$ & 35.5 & - \\
\hline 504 & $\begin{array}{c}2838 \\
\text { Sino Biological }\end{array}$ & $\begin{array}{c}\text { MM43[43] } \\
\text { AbCellera clone }\end{array}$ & - & 179.5 & 522 & $\begin{array}{c}\text { Sino Biological } \\
40150-D 002\end{array}$ & $\begin{array}{c}\text { AbCellera clone } \\
429\end{array}$ & - & 243.5 & 539 & $\begin{array}{c}\text { Sino Biological } \\
40150-D 003\end{array}$ & $\begin{array}{c}\text { AbCellera clone } \\
131\end{array}$ & 52.5 & - \\
\hline 505 & 40150-D001 & $\begin{array}{c}131 \\
\text { Creative }\end{array}$ & 38 & - & 523 & $\begin{array}{c}\text { Sino Biological } \\
40150-D 002\end{array}$ & $\begin{array}{c}\text { AbCellera clone } \\
459\end{array}$ & - & 11 & 540 & $\begin{array}{c}\text { Sino Biological } \\
40150-D 003\end{array}$ & $\begin{array}{c}\text { AbCellera clone } \\
277\end{array}$ & - & 316.5 \\
\hline & Sino Biological & $\begin{array}{c}\text { Diagnostics } \\
\text { CABT- }\end{array}$ & & & 524 & $\begin{array}{c}\text { Sino Biological } \\
40150-D 002\end{array}$ & $\begin{array}{c}\text { AbCellera clone } \\
525\end{array}$ & - & 260.5 & 541 & $\begin{array}{c}\text { Sino Biological } \\
40150-D 003\end{array}$ & $\begin{array}{c}\text { AbCellera clone } \\
283\end{array}$ & - & 345 \\
\hline 506 & 40150-D001 & $\begin{array}{l}\text { CS031[BIB112] } \\
\text { Creative }\end{array}$ & 43.5 & - & & & $\begin{array}{c}\text { Creative } \\
\text { Diagnostics }\end{array}$ & & & 542 & $\begin{array}{c}\text { Sino Biological } \\
40150-D 003\end{array}$ & $\begin{array}{c}\text { AbCellera clone } \\
291\end{array}$ & - & 146 \\
\hline & Sino Biological & $\begin{array}{c}\text { Diagnostics } \\
\text { CABT- }\end{array}$ & & & 525 & $\begin{array}{l}\text { Sino Biological } \\
40150-D 002\end{array}$ & $\begin{array}{c}\text { CABT- } \\
\text { CS031[BIB112] }\end{array}$ & 53.5 & - & 543 & $\begin{array}{c}\text { Sino Biological } \\
40150-D 003\end{array}$ & $\begin{array}{l}\text { AbCellera clone } \\
308\end{array}$ & - & 249.5 \\
\hline 507 & 40150-D001 & CS033[BIB114] & 43 & - & & & Creative & & & & Sino Biological & AbCellera clone & & \\
\hline 508 & $\begin{array}{c}\text { Sino Biological } \\
40150-D 001\end{array}$ & $\begin{array}{c}\text { Sino Biological } \\
40150-D 001\end{array}$ & 22.5 & - & & Sino Biological & $\begin{array}{c}\text { Diagnostics } \\
\text { CABT- }\end{array}$ & & & 544 & $\begin{array}{l}\text { 40150-D003 } \\
\text { Sino Biological }\end{array}$ & $\begin{array}{c}310 \\
\text { AbCellera clone }\end{array}$ & - & 448.5 \\
\hline 509 & $\begin{array}{c}\text { Sino Biological } \\
40150-D 001\end{array}$ & $\begin{array}{c}\text { Sino Biological } \\
\text { 40150-D002 }\end{array}$ & 28 & - & 526 & 40150-D002 & CS033[BIB114] & 62.5 & - & 545 & 40150-D003 & 313 & - & 241.5 \\
\hline
\end{tabular}




\begin{tabular}{|c|c|c|c|c|c|c|c|c|c|c|c|c|c|c|}
\hline \multirow[b]{2}{*}{ Index } & \multirow{2}{*}{$\begin{array}{l}\text { Capture } \\
\text { antibody }\end{array}$} & \multirow{2}{*}{$\begin{array}{l}\text { Detector } \\
\text { antibody }\end{array}$} & \multicolumn{2}{|c|}{ Average rank } & \multirow[b]{2}{*}{ Index } & \multirow{2}{*}{$\begin{array}{l}\text { Capture } \\
\text { antibody }\end{array}$} & \multirow{2}{*}{$\begin{array}{l}\text { Detector } \\
\text { antibody }\end{array}$} & \multicolumn{2}{|c|}{ Average rank } & \multirow[b]{2}{*}{ Index } & \multirow{2}{*}{$\begin{array}{l}\text { Capture } \\
\text { antibody }\end{array}$} & \multirow{2}{*}{$\begin{array}{l}\text { Detector } \\
\text { antibody }\end{array}$} & \multicolumn{2}{|c|}{ Average rank } \\
\hline & & & round 1 & round 2 & & & & round 1 & round 2 & & & & round 1 & round 2 \\
\hline 546 & $\begin{array}{c}\text { Sino Biological } \\
40150-D 003\end{array}$ & $\begin{array}{c}\text { AbCellera clone } \\
353\end{array}$ & - & 456.5 & 563 & $\begin{array}{c}\text { Sino Biological } \\
40150-D 003\end{array}$ & $\begin{array}{c}\text { Sino Biological } \\
\text { 40150-D001 }\end{array}$ & 4.5 & 156.5 & & & $\begin{array}{c}\text { Creative } \\
\text { Diagnostics }\end{array}$ & & \\
\hline 547 & $\begin{array}{c}\text { Sino Biological } \\
40150-D 003\end{array}$ & $\begin{array}{c}\text { AbCellera clone } \\
397\end{array}$ & - & 505.5 & 564 & $\begin{array}{c}\text { Sino Biological } \\
40150-D 003\end{array}$ & $\begin{array}{c}\text { Sino Biological } \\
40150-D 002\end{array}$ & 1 & 302 & 581 & $\begin{array}{c}\text { Sino Biological } \\
40150-D 004\end{array}$ & $\begin{array}{c}\text { CABT- } \\
\text { CS033[BIB114] }\end{array}$ & 51 & - \\
\hline 548 & $\begin{array}{c}\text { Sino Biological } \\
40150-D 003\end{array}$ & $\begin{array}{c}\text { AbCellera clone } \\
415\end{array}$ & - & 447 & 565 & $\begin{array}{c}\text { Sino Biological } \\
40150-D 003\end{array}$ & $\begin{array}{c}\text { Sino Biological } \\
\text { 40150-D003 }\end{array}$ & 34.5 & - & 582 & $\begin{array}{c}\text { Sino Biological } \\
40150-D 004\end{array}$ & $\begin{array}{c}\text { Leinco clone } \\
2146\end{array}$ & - & 209.5 \\
\hline 549 & $\begin{array}{c}\text { Sino Biological } \\
40150-D 003\end{array}$ & $\begin{array}{l}\text { AbCellera clone } \\
429\end{array}$ & - & 253 & 566 & $\begin{array}{c}\text { Sino Biological } \\
40150-D 003\end{array}$ & $\begin{array}{l}\text { Sino Biological } \\
\text { 40150-D004 }\end{array}$ & 15.5 & 408.5 & 583 & $\begin{array}{l}\text { Sino Biological } \\
\text { 40150-D004 }\end{array}$ & $\begin{array}{l}\text { Leinco clone } \\
2197\end{array}$ & - & 93.5 \\
\hline 550 & $\begin{array}{c}\text { Sino Biological } \\
40150-D 003\end{array}$ & $\begin{array}{c}\text { AbCellera clone } \\
447\end{array}$ & - & 293.5 & 567 & $\begin{array}{c}\text { Sino Biological } \\
40150-D 003\end{array}$ & $\begin{array}{c}\text { Sino Biological } \\
40150-R 007\end{array}$ & 60.5 & - & 584 & $\begin{array}{c}\text { Sino Biological } \\
40150-D 004\end{array}$ & $\begin{array}{c}\text { Leinco clone } \\
2215\end{array}$ & - & 107 \\
\hline 551 & $\begin{array}{c}\text { Sino Biological } \\
40150-D 003\end{array}$ & $\begin{array}{c}\text { AbCellera clone } \\
459\end{array}$ & - & 109 & 568 & $\begin{array}{c}\text { Sino Biological } \\
40150-D 004\end{array}$ & $\begin{array}{c}\text { AbCellera clone } \\
131\end{array}$ & 42.5 & - & 585 & $\begin{array}{l}\text { Sino Biological } \\
40150-D 004\end{array}$ & $\begin{array}{c}\text { Leinco clone } \\
2355\end{array}$ & - & 39 \\
\hline 552 & $\begin{array}{c}\text { Sino Biological } \\
40150-D 003\end{array}$ & $\begin{array}{l}\text { AbCellera clone } \\
525\end{array}$ & - & 378 & 569 & $\begin{array}{c}\text { Sino Biological } \\
40150-D 004\end{array}$ & $\begin{array}{c}\text { AbCellera clone } \\
277\end{array}$ & - & 187 & 586 & $\begin{array}{c}\text { Sino Biological } \\
40150-D 004\end{array}$ & $\begin{array}{l}\text { Leinco clone } \\
2381\end{array}$ & - & 32 \\
\hline & & $\begin{array}{c}\text { Creative } \\
\text { Diagnostics }\end{array}$ & & & 570 & $\begin{array}{c}\text { Sino Biological } \\
40150-D 004\end{array}$ & $\begin{array}{l}\text { AbCellera clone } \\
283\end{array}$ & - & 191.5 & 587 & $\begin{array}{l}\text { Sino Biological } \\
40150-D 004\end{array}$ & $\begin{array}{c}\text { Leinco clone } \\
2838\end{array}$ & - & 42.5 \\
\hline 553 & $\begin{array}{c}\text { Sino Biological } \\
40150-D 003\end{array}$ & $\begin{array}{c}\text { CABT- } \\
\text { CS031[BIB112] }\end{array}$ & 6.5 & - & 571 & $\begin{array}{c}\text { Sino Biological } \\
40150-D 004\end{array}$ & $\begin{array}{c}\text { AbCellera clone } \\
291\end{array}$ & - & 71 & 588 & $\begin{array}{l}\text { Sino Biological } \\
40150-D 004\end{array}$ & $\begin{array}{c}\text { Sino Biological } \\
40150-D 001\end{array}$ & 4 & - \\
\hline & & $\begin{array}{c}\text { Creative } \\
\text { Diagnostics }\end{array}$ & & & 572 & $\begin{array}{c}\text { Sino Biological } \\
40150-D 004\end{array}$ & $\begin{array}{l}\text { AbCellera clone } \\
308\end{array}$ & - & 64 & 589 & $\begin{array}{l}\text { Sino Biological } \\
40150-D 004\end{array}$ & $\begin{array}{c}\text { Sino Biological } \\
40150-D 002\end{array}$ & 2.5 & - \\
\hline 554 & $\begin{array}{c}\text { Sino Biological } \\
40150-D 003\end{array}$ & $\begin{array}{c}\text { CABT- } \\
\text { CS033[BIB114] }\end{array}$ & 47 & - & 573 & $\begin{array}{c}\text { Sino Biological } \\
40150-D 004\end{array}$ & $\begin{array}{l}\text { AbCellera clone } \\
310\end{array}$ & - & 331 & 590 & $\begin{array}{c}\text { Sino Biological } \\
40150-D 004\end{array}$ & $\begin{array}{c}\text { Sino Biological } \\
40150-D 003\end{array}$ & 63.5 & - \\
\hline 555 & $\begin{array}{c}\text { Sino Biological } \\
40150-D 003\end{array}$ & $\begin{array}{c}\text { Leinco clone } \\
2136\end{array}$ & - & 286.5 & 574 & $\begin{array}{c}\text { Sino Biological } \\
40150-D 004\end{array}$ & $\begin{array}{l}\text { AbCellera clone } \\
313\end{array}$ & - & 55.5 & 591 & $\begin{array}{l}\text { Sino Biological } \\
40150-D 004\end{array}$ & $\begin{array}{c}\text { Sino Biological } \\
40150-D 004\end{array}$ & 15.5 & 289.5 \\
\hline 556 & $\begin{array}{c}\text { Sino Biological } \\
40150-D 003\end{array}$ & $\begin{array}{c}\text { Leinco clone } \\
2143\end{array}$ & - & 191.5 & 575 & $\begin{array}{c}\text { Sino Biological } \\
40150-D 004\end{array}$ & $\begin{array}{c}\text { AbCellera clone } \\
\quad 353\end{array}$ & - & 247 & 592 & $\begin{array}{l}\text { Sino Biological } \\
40150-D 004\end{array}$ & $\begin{array}{c}\text { Sino Biological } \\
40150-R 007\end{array}$ & 24.5 & - \\
\hline 557 & $\begin{array}{c}\text { Sino Biological } \\
40150-D 003\end{array}$ & $\begin{array}{c}\text { Leinco clone } \\
2146\end{array}$ & - & 320.5 & 576 & $\begin{array}{c}\text { Sino Biological } \\
40150-D 004\end{array}$ & $\begin{array}{c}\text { AbCellera clone } \\
397\end{array}$ & - & 510.5 & & $\begin{array}{c}\text { Sino Biological } \\
\text { 40591- }\end{array}$ & AbCellera clone & & \\
\hline 558 & $\begin{array}{c}\text { Sino Biological } \\
40150-D 003\end{array}$ & $\begin{array}{c}\text { Leinco clone } \\
2197\end{array}$ & - & 366.5 & 577 & $\begin{array}{c}\text { Sino Biological } \\
40150-D 004\end{array}$ & $\begin{array}{l}\text { AbCellera clone } \\
4429\end{array}$ & - & 95 & 593 & $\begin{array}{c}\text { MM43[43] } \\
\text { Sino Biological }\end{array}$ & 277 & - & 381 \\
\hline 559 & $\begin{array}{c}\text { Sino Biological } \\
40150-D 003\end{array}$ & $\begin{array}{c}\text { Leinco clone } \\
2215\end{array}$ & - & 294 & 578 & $\begin{array}{c}\text { Sino Biological } \\
40150-D 004\end{array}$ & $\begin{array}{c}\text { AbCellera clone } \\
459\end{array}$ & - & 26.5 & 594 & $\begin{array}{c}\text { 40591- } \\
\text { MM43[43] }\end{array}$ & $\begin{array}{c}\text { AbCellera clone } \\
283\end{array}$ & - & 445 \\
\hline 560 & $\begin{array}{l}\text { Sino Biological } \\
40150-D 003 \\
\text { Sino Biological }\end{array}$ & $\begin{array}{l}\text { Leinco clone } \\
2355 \\
\text { Leinco clone }\end{array}$ & - & 120.5 & 579 & $\begin{array}{c}\text { Sino Biological } \\
40150-D 004\end{array}$ & $\begin{array}{c}\text { AbCellera clone } \\
525 \\
\text { Creative }\end{array}$ & - & 184.5 & 595 & $\begin{array}{c}\text { Sino Biological } \\
40591- \\
\text { MM43[43] }\end{array}$ & $\begin{array}{c}\text { AbCellera clone } \\
291\end{array}$ & - & 105 \\
\hline 561 & $\begin{array}{c}\text { 40150-D003 } \\
\text { Sino Biological } \\
40150-D 003\end{array}$ & $\begin{array}{c}2381 \\
\text { Leinco clone } \\
2838\end{array}$ & - & 120.5 & 580 & $\begin{array}{c}\text { Sino Biological } \\
40150-D 004\end{array}$ & $\begin{array}{c}\text { Diagnostics } \\
\text { CABT- } \\
\text { CS031[BIB112] }\end{array}$ & 8 & - & 596 & $\begin{array}{c}\text { Sino Biological } \\
40591- \\
\text { MM43[43] }\end{array}$ & $\begin{array}{l}\text { AbCellera clone } \\
308\end{array}$ & - & 81 \\
\hline
\end{tabular}




\begin{tabular}{|c|c|c|c|c|c|c|c|c|c|c|c|c|c|c|}
\hline \multirow[b]{2}{*}{ Index } & \multirow{2}{*}{$\begin{array}{l}\text { Capture } \\
\text { antibody }\end{array}$} & \multirow{2}{*}{$\begin{array}{l}\text { Detector } \\
\text { antibody }\end{array}$} & \multicolumn{2}{|c|}{ Average rank } & \multirow[b]{2}{*}{ Index } & \multirow{2}{*}{$\begin{array}{l}\text { Capture } \\
\text { antibody }\end{array}$} & \multirow{2}{*}{$\begin{array}{l}\text { Detector } \\
\text { antibody }\end{array}$} & \multicolumn{2}{|c|}{ Average rank } & \multirow[b]{2}{*}{ Index } & \multirow{2}{*}{$\begin{array}{l}\text { Capture } \\
\text { antibody }\end{array}$} & \multirow{2}{*}{$\begin{array}{l}\text { Detector } \\
\text { antibody }\end{array}$} & \multicolumn{2}{|c|}{ Average rank } \\
\hline & & & round 1 & round 2 & & & & round 1 & round 2 & & & & round 1 & round 2 \\
\hline 597 & $\begin{array}{c}\text { Sino Biological } \\
40591- \\
\text { MM43[43] }\end{array}$ & $\begin{array}{c}\text { AbCellera clone } \\
310\end{array}$ & - & 510.5 & 605 & $\begin{array}{c}\text { Sino Biological } \\
40591- \\
\text { MM43[43] }\end{array}$ & $\begin{array}{l}\text { Leinco clone } \\
2136\end{array}$ & - & 341.5 & 613 & $\begin{array}{c}\text { Sino Biological } \\
40591- \\
\text { MM43[43] }\end{array}$ & $\begin{array}{c}\text { Sino Biological } \\
40150-D 004\end{array}$ & - & 76.5 \\
\hline & $\begin{array}{c}\text { Sino Biological } \\
40591-\end{array}$ & AbCellera clone & & & & $\begin{array}{c}\text { Sino Biological } \\
\text { 40591- }\end{array}$ & Leinco clone & & & 614 & $\begin{array}{l}\text { Sino Biological } \\
40150-\text { R007 }\end{array}$ & $\begin{array}{c}\text { AbCellera clone } \\
131\end{array}$ & 53.5 & - \\
\hline 598 & MM43[43] & 313 & - & 57 & 606 & MM43[43] & 2143 & - & 27 & & & Creative & & \\
\hline 599 & $\begin{array}{c}\text { Sino Biological } \\
\text { 40591- } \\
\text { MM43[43] }\end{array}$ & $\begin{array}{c}\text { AbCellera clone } \\
353\end{array}$ & - & 470 & 607 & $\begin{array}{c}\text { Sino Biological } \\
40591- \\
\text { MM43[43] }\end{array}$ & $\begin{array}{c}\text { Leinco clone } \\
2146\end{array}$ & - & 292 & 615 & $\begin{array}{c}\text { Sino Biological } \\
40150-R 007\end{array}$ & $\begin{array}{c}\text { Diagnostics } \\
\text { CABT- } \\
\text { CS031[BIB112] }\end{array}$ & 22 & - \\
\hline 600 & $\begin{array}{c}\text { Sino Biological } \\
40591- \\
\text { MM43[43] }\end{array}$ & $\begin{array}{c}\text { AbCellera clone } \\
397\end{array}$ & - & 548 & 608 & $\begin{array}{c}\text { Sino Biological } \\
40591- \\
\text { MM43[43] }\end{array}$ & $\begin{array}{c}\text { Leinco clone } \\
2197\end{array}$ & - & 230 & & Sino Biological & $\begin{array}{c}\text { Creative } \\
\text { Diagnostics } \\
\text { CABT- }\end{array}$ & & \\
\hline 601 & $\begin{array}{c}\text { Sino Biological } \\
\text { 40591- } \\
\text { MM43[43] }\end{array}$ & $\begin{array}{l}\text { AbCellera clone } \\
4229\end{array}$ & - & 153.5 & 609 & $\begin{array}{c}\text { Sino Biological } \\
40591- \\
\text { MM43[43] }\end{array}$ & $\begin{array}{c}\text { Leinco clone } \\
2215\end{array}$ & - & 310.5 & 616 & $\begin{array}{l}\text { 40150-R007 } \\
\text { Sino Biological } \\
\text { 40150-R007 }\end{array}$ & $\begin{array}{c}\text { CS033[BIB114] } \\
\text { Sino Biological } \\
40150-D 001\end{array}$ & 59.5 & - \\
\hline & $\begin{array}{c}\text { Sino Biological } \\
40591-\end{array}$ & AbCellera clone & & & & $\begin{array}{c}\text { Sino Biological } \\
40591-\end{array}$ & Leinco clone & & & 618 & $\begin{array}{c}\text { Sino Biological } \\
40150-\text { R007 }\end{array}$ & $\begin{array}{c}\text { Sino Biological } \\
40150-D 002\end{array}$ & 40 & - \\
\hline 602 & $\begin{array}{c}\text { MM43[43] } \\
\text { Sino Biological }\end{array}$ & 447 & - & 278 & 610 & $\begin{array}{c}\text { MM43[43] } \\
\text { Sino Biological }\end{array}$ & 2355 & - & 11 & 619 & $\begin{array}{c}\text { Sino Biological } \\
40150-R 007\end{array}$ & $\begin{array}{c}\text { Sino Biological } \\
40150-D 003\end{array}$ & 26 & - \\
\hline 603 & $\begin{array}{c}\text { 40591- } \\
\text { MM43[43] }\end{array}$ & $\begin{array}{l}\text { AbCellera clone } \\
459\end{array}$ & - & 51 & 611 & $\begin{array}{c}\text { 40591- } \\
\text { MM43[43] }\end{array}$ & $\begin{array}{l}\text { Leinco clone } \\
2381\end{array}$ & - & 68 & 620 & $\begin{array}{c}\text { Sino Biological } \\
40150-\text { R007 }\end{array}$ & $\begin{array}{c}\text { Sino Biological } \\
40150-D 004\end{array}$ & 19 & - \\
\hline & $\begin{array}{c}\text { Sino Biological } \\
40591-\end{array}$ & AbCellera clone & & & & $\begin{array}{c}\text { Sino Biological } \\
40591-\end{array}$ & Leinco clone & & & 621 & $\begin{array}{l}\text { Sino Biological } \\
40150-R 007\end{array}$ & $\begin{array}{c}\text { Sino Biological } \\
40150-\text { R007 }\end{array}$ & 61 & - \\
\hline 604 & MM43[43] & 525 & - & 173.5 & 612 & MM43[43] & 2838 & - & 53.5 & & & & & \\
\hline
\end{tabular}


